\title{
Natural Gas Engine Technologies: Challenges and Energy Sustainability Issue
}

\author{
Girma T. Chala ${ }^{1}$ (D), Abd Rashid Abd Aziz ${ }^{2}$ and Ftwi Y. Hagos ${ }^{3,4, *(1)}$ \\ 1 Department of Mechanical Engineering, International College of Engineering and Management, P.O. Box \\ 2511, C.P.O Seeb 111, Sultanate of Oman; girma_tade@yahoo.com \\ 2 Center for Automotive Research and Electric Mobility (CAREM), Universiti Teknologi Petronas, \\ Tronoh 31750, Perak, Malaysia; rashid@utp.edu.my \\ 3 Advance Fluids Focus Group, Faculty of Mechanical Engineering, Universiti Malaysia Pahang, \\ Kuantan 26600, Malaysia \\ 4 Automotive Engineering Centre, Universiti Malaysia Pahang, Kuantan 26600, Malaysia \\ * Correspondence: ftwi@ump.edu.my; Tel.: +60-942-463-67
}

Received: 27 July 2018; Accepted: 27 August 2018; Published: 27 October 2018

\begin{abstract}
Energy sustainability and environmental issues pose greater challenges on different primary energy sectors as the global energy demand increases and it is projected to further increase with an upsurge in population. On the other hand, energy sources from conventional fossil-based fuels are depleting, forcing explorations in challenging and difficult locations. As a result, the use of alternative fuels received dramatic consideration to substitute these conventional fuels, of which natural gas took the significant share. However, the share of natural-gas vehicles in the current vehicle market is quite small, and it is estimated to be below $5 \%$. This paper reviews the current resource scenarios including proven and potential reserves, current production, and consumption, along with the fueling infrastructure, distribution, and storage. It also provides summary of the development of fuel-injection technologies aimed to enhance the performance of gas engines. More attention was also given to natural-gas engines and their limitations. Parameters affecting the performance and combustion of compressed natural gas (CNG) in spark-ignition (SI) engines are thoroughly assessed, among which compression ratio and injection timing play major roles in the optimization of CNG-fueled engines. Furthermore, different technologies that help close the performance gap between conventional liquid-fuel and natural-gas engines and future directions of the research are presented.
\end{abstract}

Keywords: natural gas; transport; SI engine; compression-ignition (CI) engine; performance; emissions

\section{Introduction}

Due to an increase in pollution from automotive vehicles running on conventional liquid fuels, alternative fuels that could result in similar performance became potential candidates to be used as substitutes in short and long-term plans [1]. In the upcoming years, alternative fuels are expected to substitute conventional fuels concerning environmental and energy security issues. While the future trend in the transportation sector is inclining toward electric vehicles, a leap jump is unlikely due to existing infrastructure and resources. There is a need for an alternative transitional fuel that can lead toward 21st century ambitions of zero-carbon emission. As a result, natural gas has become the leading candidate to fill the gap in recent trends [2].

Natural gas has been used as vehicle fuel since the 1920s. Significant development of natural gas was seen during the oil shocks in 1974 and 1979. Natural gas has become the most favorable energy source capable of matching the energy density and combustion-related issues in the engine [3]. Natural gas is also a leading candidate for transportation vehicles in many countries mainly due 
to its vast abundance, its price, lower emission rates, and suitability of use in conventional diesel and gasoline engines. In fact, natural-gas combustion produces the lowest greenhouse-gas emissions of fossil fuels, together with a minimal level of suspended particles [4]. As a result, natural gas received great acceptance for fueling vehicles in recent years, and this is likely to rise in the coming years [5]. Over the last few years, the discovery of shale gas and an advancement in unconventional gas production prompted further focus to natural gas. The discovery of natural gas geographically and globally diversified the production of natural gas. According to the International Energy Outlook 2016 (IEO2016) and Annual Energy Outlook 2016 (AEO2016), shale gas is expected to claim up to 30\% of the global natural-gas production share by 2040.

Despite all the advantages of fuel and its increasing volume of production, the market share of natural-gas vehicles is too low, comprising only $1.27 \%$ [6], and the growth rate is forecasted at $5-7 \%$ annually [7]. This weak growth does not match the rapidly increasing growth of transportation vehicles. The attributes to this are a common misconception, operational problems associated with retrofitted engines, storage size, and safety, in addition to a lack of advancement in fuel-conversion technologies, and a greater expectation for the fuel-conversion efficiency in a pollution and energy-saving context being among other contributing factors. Over a two-decade period, there was significant research work to overcome such challenges. Moreover, there were a few review works compiling the works that highlighted the investigation and development of natural-gas vehicles, mainly based on the fuel-conversion technologies and their limitations [8-11]. However, these reviews barely touched the research data in the last decade, except for an effort by Khan et al. (2016) in their bibliographic review [12].

Therefore, the aim of the current review is to highlight the progress on the development of natural-gas-fueled engines for the transportation sector and their technological limitations. This review work targeted the expanding global resource of natural gas, the fueling infrastructure development, the natural-gas fuel-conversion technologies and their technical and operational limitations, and finally, in the conclusions and perspective section, focused on the latest advanced technologies and future technological trends.

\section{Natural-Gas Resources: Global Perspective}

The world's energy demand increased in last decade, and different energy sources are utilized to fulfill the need $[13,14]$. Conventional fossil fuels, including coal and oil, took the lion's share of the energy sources over the last few years [15]. However, this proved to have many disadvantages in terms of emission and human health, especially in cities with high population [16,17]. Many efforts were made to combat this growing issue, one of which was the use of alternative fuels in different sectors $[18,19]$. Table 1 shows world energy consumption by fuel over the past 15 years. Globally, natural gas is the third major energy source, where its use increased over the last decade as opposed to coal and oil. Supply from the major shareholders of energy sources, coal and oil, was observed to decrease in the last ten years, from $33.49 \%$ to $32.94 \%$ for oil and from $29.84 \%$ to $29.20 \%$ for coal.

Table 1. Global energy consumption by fuel in 2005, 2010, and 2015 adapted from the World Energy Council (WEC) [20].

\begin{tabular}{cccc}
\hline \multirow{2}{*}{ Fuel Type } & \multicolumn{3}{c}{ Consumption in Percentage } \\
\cline { 2 - 4 } & $\mathbf{2 0 0 5}$ & $\mathbf{2 0 1 0}$ & $\mathbf{2 0 1 5}$ \\
\hline Oil & 35.96 & 33.49 & 32.94 \\
Gas & 22.89 & 23.7 & 23.85 \\
Hydro & 6.05 & 6.44 & 6.79 \\
Solar & 1.01 & 0.06 & 0.45 \\
Coal & 28.61 & 29.84 & 29.20 \\
Nuclear & 5.73 & 5.14 & 4.44 \\
Wind & 0.22 & 0.63 & 1.44 \\
Other renewables & 0.54 & 0.70 & 0.89 \\
\hline
\end{tabular}


Due to the reduced reserves of petroleum resources, alternative fuels such as natural gas would lighten the dependency on conventional fossil fuels. This was predicted to increase the natural-gas demand by up to $50 \%$ in 2035 from 2010 [21]. Natural gas is a cleaner energy source that reduces the carbon emissions by $20-30 \%$ as compared to conventional fuels. Moreover, natural gas is regarded as the primary fuel source for gaining energy security in the long term [22,23]. It was reported that natural gas would be a potential fuel for sustainable energy sources after $2050[24,25]$.

\subsection{Proven Natural-Gas Reserves}

Globally, there is an abundance of natural resources [26]. Table 2 shows a comparison of natural-gas reserves between 2005, 2015, and 2017. Natural-gas reserves amounted to 186.9 trillion cubic meters (tcm) in 2015, and there were $157.3 \mathrm{tcm}$ in 2005, showing more than a $15 \%$ increase in a decade. The largest reserve in 2015 was found in the Middle East, which holds $42.8 \%$, followed by Europe and Eurasia (30.4\%), the Asia-Pacific (8.4\%), Africa (7.5\%), North America (6.8\%), and South and Central America (4.1\%). Many end sectors are motivated by the abundant resources of natural gas [27]. The proven reserves are much greater than that for conventional liquid fuels in 2017: $193.5 \mathrm{tcm}$ versus 270 billion cubic meters $(\mathrm{bcm})$, which further encourages the comprehensive utilization of natural gas.

Table 2. Global proven natural-gas reserves, in percentage: comparison between 2005, 2015, and 2017, adapted from British Petroleum (BP) [28].

\begin{tabular}{cccc}
\hline \multirow{2}{*}{ Region } & \multicolumn{3}{c}{ Proven Reserves in Percentage } \\
\cline { 2 - 4 } & Year 2005 & Year 2015 & Year 2017 \\
\hline Middle East & 46.2 & 42.8 & 40.9 \\
Europe and Eurasia & 27.3 & 30.4 & 32.1 \\
Asia-Pacific & 8.2 & 8.4 & 10.0 \\
Africa & 8.9 & 7.5 & 7.1 \\
North America & 5.0 & 6.8 & 5.6 \\
South and Central America & 4.4 & 4.1 & 4.2 \\
Total (in trillion cubic meters) & 157.3 & 186.9 & 193.5 \\
\hline
\end{tabular}

Natural gas is being discovered in different geographical regions of the globe [29]. There are two forms of natural-gas reserves: conventional and unconventional [30]. Unconventional natural-gas reserves are categorized into four: coalbed methane or coal-seam gas, shale gas, gas from tight sandstones or tight gas, and methane hydrates (least known). Conventional gas is produced from permeability reservoirs, while shale gas is produced from lower permeable mudstone. Coalbed methane is expensive due to the requirement of water disposal, while tight sands need high developmental costs. Among proven global natural-gas reserves, $4 \%$ of them are unconventional gas, including shale gas, coal-seam gas, and tight gas. The Asia-Pacific holds $30 \%$ of the unconventional gas reserves, North America holds $25 \%$, and $17 \%$ of the total unconventional reserves were found in the former Soviet Union. This increased unconventional gas shares to $15 \%$ from $12 \%$ in 2007 [31].

\subsection{Global Potential Reserves}

Natural-gas resources are believed to be enormous with vast recoverable reserves worldwide. The global natural-gas reserves were estimated to be $186.9 \mathrm{tcm}$ in 2015, as shown in Table 2, representing only $22 \%$ of the total gas reserves worldwide according to Economides et al. (2011). According to this report, there is a potential of $662.33 \mathrm{tcm}$ of gas reserves that can be recovered, and this amounts to $78 \%$ of the world's total proven plus potential reserves [32]. The substantial quantity of natural-gas resources emboldens applications of natural gas in different sectors.

Despite the enormous amount of recoverable gas available worldwide, there are technical challenges that are encountered during gas production. Recent advancement of technologies, such as hydraulic fraction and horizontal drilling, are widely utilized to alleviate the problems. As a result, 
a huge amount of shale gas is being produced. Song et al. [33] studied how natural gas can be produced from methane hydrates via thermal stimulation or depressurization, and using both simultaneously. With advanced technology in many countries, the use of natural gas as an energy source is feasible and expected to intensify significantly, which would finally support countries in shifting from coal and oil dependencies soon. Chong et al. [34] stated that natural gas is a strong candidate for an energy source in the future compared to coal and oil. They highlighted that natural gas could also be explored from hydrate resources, which are considered as the largest sources of carbon.

\subsection{Current Production Capacity and Consumption}

Production of natural gas was instigated from coal in Britain in 1785, followed by drilling from the earth's core [35]. Fei et al. [36] described that natural gas could be produced from fossil resources or anthropogenic resources. Currently, natural gas is produced from both unconventional and conventional gas resources. Hydraulic fracturing (HF), which involves removing gas from the rock following drilling in depth, contributed to the higher production of natural gas recently [37]. Natural-gas production grows by an average of $2.5 \%$ every year. Almost equivalently, world natural-gas consumption also increased in the last decade [38]. The global consumption growth was estimated at $1.7 \%$ in 2015 . Natural-gas production and consumption were both observed to increase in the last decade at averages of $2.4 \%$ and $2.3 \%$, respectively. The highest production growth was observed in North America with an estimate of 3.9\% in 2015.

The huge production in North America was mainly due to shale gas, which accounts for approximately $32 \%$ of the total reserves in the United States (US) [32]. The development of shale technology (a mechanism of recovering reserves which were thought to be unrecoverable) strengthens the production of natural gas in North America [39]. Table 3 shows the top five natural-gas-producing countries in 2015. The largest producer of natural gas was the US with $767.3 \mathrm{bcm}$, followed by Russia (573.3 bcm), Iran (192.5 bcm), Qatar (181.4 bcm), and Canada (163.5).

Table 3. Top five natural-gas-producing countries in 2015 [28].

\begin{tabular}{cc}
\hline Country & Production Amount (bcm) in 2015 \\
\hline United states & 767.3 \\
Russia & 573.3 \\
Iran & 192.5 \\
Qatar & 181.4 \\
Canada & 163.5 \\
\hline
\end{tabular}

Natural-gas production is increasing in many other countries. Nwaoha et al. [40] indicated a decline in the production of oil, but growth in the utilization of natural gas globally. However, production dropped by $1.7 \%$ in Europe and Eurasia [41]. Though domestic natural-gas production is decreasing in Europe, consumption has increased with a higher number of imports, making it $15.3 \%$ of the total global consumption in 2011 [42]. Dilaver et al. [43] reported an increase in natural-gas consumption in Europe, and their model showed an increasing trend in the future long-term natural-gas demand. Their analysis revealed that natural-gas consumption of the Organization for Economic Co-operation and Development (OECD)-Europe would be in the range of 572 to $646 \mathrm{bcm}$ by 2020 , indicating that natural gas would remain as a primary fuel source in the region. Natural-gas consumption for the European Union (EU) would be $641 \mathrm{bcm}$ in 2020 [44]. Different policies related to the environment supported the wider usage of natural gas in various sectors in the region [45].

Natural gas would play a significant role as a fuel for satisfying the energy demands due to its advantage in the long term in terms of price and its benefit in alleviating climate changes [46-48]. The last half of a decade saw dramatic growth in natural-gas production with the new technology of recovering reserves that were once thought to be unrecoverable reserves [49]. Two new extraction techniques, hydraulic fracturing and horizontal drilling, which allows the drill shaft 
to move horizontally underground, resulted in a boom in natural-gas production recently $[50,51]$. Melo-Martín et al. [52] reported growth in natural-gas production from unconventional sources using recent technologies. Natural-gas production and consumption increased in many parts of the world, and it is projected to further increase in the years to come [53].

Figure 1 compares the production of natural gas by type in the US, China, and Canada in the year 2012 and 2040. It reveals how shale technology would further increase natural-gas production worldwide. The production of natural gas from shale reserves was almost nil in China and Canada, as opposed to that in the United States in 2012. However, it was predicted that the production of gas from this reserve would be practical in many countries in 2040, increasing world natural-gas production in the coming years. Asche et al. [54] discussed that significant production of shale gas, currently considered an unconventional gas, would probably be regarded as a conventional reserve. Bazilian et al. [55] also stated the massive production of shale gas in North America and recommended researches on applicability.

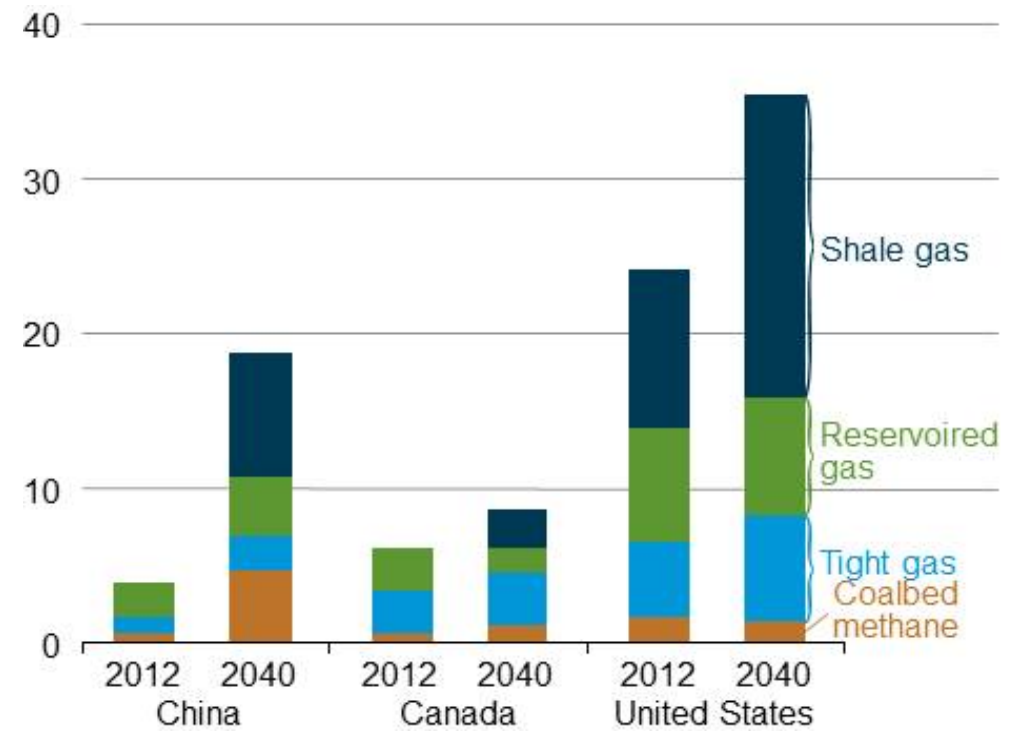

Figure 1. Production of natural gas by type in the United States, China, and Canada: comparison between 2012 and 2040 (trillion cubic feet) [56].

Shale gas is predicted to take over the dominant share in US natural-gas consumption, from $0.396 \mathrm{bcm} /$ day in 2011 to $0.62 \mathrm{bcm} /$ day in 2020 [32]. The production of shale gas increased tenfold annually in the US over the last half of a decade [57], and it is expected to reach three times the current production in 2020. Fukui et al. [58] showed the experience curve for hydraulic fracturing of unconventional natural-gas production, and reported that hydraulic fracturing increased the production of natural gas and lowered wellhead gas price recently. Arora et al. [59] conducted a simulation study showing the growth in world economic activity from 2014 to 2035 as a result of natural-gas production from shale reserves and exports from the US.

Heidari et al. [60] surveyed natural-gas consumption in Iran, and concluded that natural gas has a significant impact on the country's economic growth. Clark et al. [61] showed an increased consumption of natural gas in the US by about $4.8 \%$ due to a different policy encouraging the use of natural gas. China's numerous policies supporting the use of natural gas led to significant demand and progress [62]. As a result, the annual natural-gas output increased by $12.1 \%$ in China from 2000 to 2014 , while consumption grew by $15.1 \%$ annually. Cabalu et al. [63] indicated that increasing gas efficiency in addition to developing technologies for the vast production of natural gas would reduce imports and improve the energy security of Asian region. 
Figure 2 depicts the global consumption of natural gas by sector from 2014 to 2020 . An integrated equilibrium modeling system and a large-scale simulation model were used by the US Energy Information Administration (EIA) and International Energy Agency (IEA), respectively, to forecast natural-gas consumption. Natural gas provides the second major energy source for power generation. Natural gas consumption in the transport sector was estimated to be $11 \%$, and this is projected to increase in the future. As the global greenhouse emissions emanate from the transportation sector, representing $20 \%$ of total emissions, natural gas is being considered as an alternative fuel in the transportation sector with minimal greenhouse-gas (GHG) emissions. Economic benefit and energy security encourages the use of natural gas as vehicle fuel [64,65].

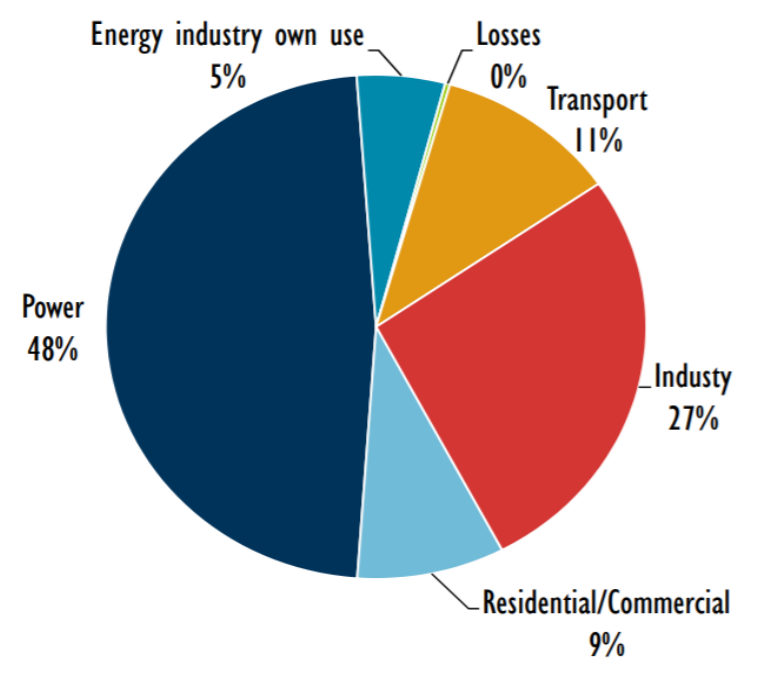

Figure 2. Global natural-gas consumption by sector (2014-2020) [66].

The technology of using natural gas in vehicles is widely adopted and well established. Moreover, the competitive price of natural gas is also another factor attracting more natural-gas vehicles $[67,68]$. For instance, the European Union's Green Paper is set to substitute 20\% of the fossil-fuel consumption for alternative fuels in the year 2020 [69]. In tandem, China is encouraging the broad adoption of natural gas in vehicles as the country faces higher urban pollution. China's fossil fuels resulted in higher GHG emissions, representing $26.4 \%$ of the global emissions [70,71]. The country plans to replace $10 \%$ of the energy source with natural gas by 2020 . Among many applications of natural gas, which include industrial use, commercial use, fertilizer production, power generation, and residential use, priority is given to natural-gas vehicles as this would reduce major urban pollution and improve quality of life. Moreover, to meet high-population needs, there will be substantial growth in the number of transportation vehicles [72]. This raises energy sustainable issues and environmental challenges [73]; thus, the country largely promotes the use of natural-gas vehicles.

\subsection{Natural Gas in the Transportation Sector}

Natural gas as vehicle fuel is the most promising way of achieving sustainable transport systems [74]. The abundance of natural gas could satisfy the fuel needed by transportation sectors [39]. Moreover, natural gas would offer reduced emissions of $20-30 \%$ for $\mathrm{CO}_{2}, 70-90 \%$ for $\mathrm{CO}, 75-95 \%$ for $\mathrm{NO}_{2}, 89 \%$ for volatile organic compounds, $90 \%$ for particulate matter, and $99 \%$ for $\mathrm{SO}_{2}$ than that of diesel fuel. Moreover, natural gas is considered as an efficient and clean fuel $[75,76]$. As a result, more than 86 countries are using natural gas to power vehicles [77].

Natural-gas vehicles are increasing in number worldwide. Figure 3 shows the number of global natural-gas vehicles over the last two decades. There were around 26.13 million natural-gas vehicles worldwide in June 2018. The number of vehicles was only 9.5 million in 2009 , and this was only $1 \%$ of the total number of vehicles in the same year. It was predicted that the number of natural-gas 
vehicles will be more than 30 million by 2021, getting more attention as an energy source for the transportation sector.

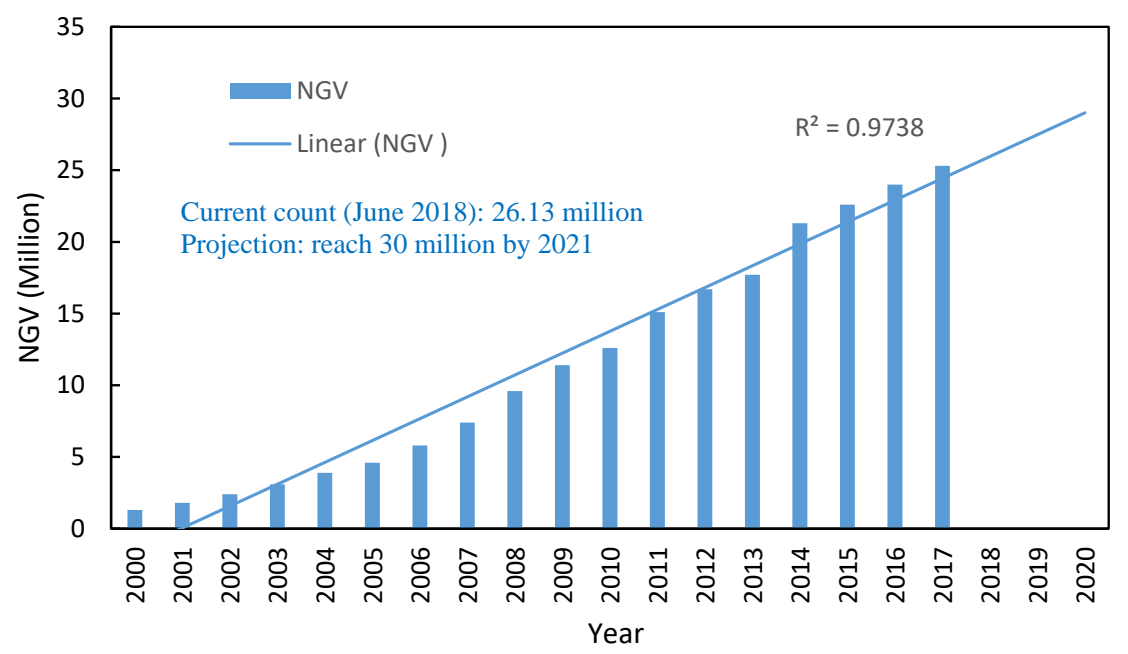

Figure 3. Total worldwide number of natural-gas vehicles from 2000 to June 2018 [78].

Figure 4 shows the statistics of the number of global natural-gas vehicles (NGVs) by region. The number of NGVs is highest in the Asia-Pacific, followed by South America, North America, Europe, the Middle East, and Africa. Around 15 million natural-gas vehicles are found in the Asia-Pacific, where the region saw significant growth in the number of NGVs over the last decade. In contrast, even though natural-gas consumption increased by $4 \%$ in 2015 compared to 2014 in Europe, amounting to $426.3 \mathrm{bcm}$ produced [79], the share of NGVs is extremely small compared to other sectors: residential, industry, and power. Engerer et al. [80] studied the options of using natural gas in vehicles in Europe, where natural-gas vehicles are few compared to their number in Asia and Latin America, due to its dependence on gas imports. As a result, the transportation sector is almost completely fueled by conventional liquid fuel, covering approximately $90 \%$ [81]. Osorio-Tejada et al. [82] reported that one-quarter of the GHG emissions in Europe emanate from the transport sector. Recently, European countries widely encourage the use of natural gas as a vehicle fuel to combat the overgrowing greenhouse-gas emissions. The governments have tax-reduction incentives in place, encouraging consumers to use natural-gas vehicles widely. In terms of import issues, it was proposed that an improved efficiency of natural gas would reduce the consumption and import costs at times of deficit, thereby expanding the broad adoption of NGVs in the region. Bilgin et al. [83] recommended that energy policies allowing more and diversified suppliers of natural gas could be regarded as one of the options to improve energy security in Europe.

The number of vehicles in Latin America has increased over the last decade. The motive of reducing imports of oil led to some Latin American countries searching for natural-gas vehicles in 1980. However, the advancement came with some incentives, such as reducing taxes compared to gasoline and diesel vehicles. In areas of highly polluted cities, the ban on the use of conventional fuels is inclusive of natural gas too. More importantly, shifting conventional liquid-fuel engines to compressed natural gas (CNG)-fueled engines does not affect the appearance of the vehicle, and as a result, it does not change the physical appearance for customer consideration.

Table 4 shows the top 10 countries by natural-gas vehicle population. The largest number of NG vehicles is found in China, totaling around six million and representing $23.2 \%$ of the total number of NGVs worldwide. Hao et al. [84] reviewed natural-gas vehicles in China. They reported that natural gas would be a potential fuel for sustainable transportation in China. The growth is substantial in the Asia-Pacific and Latin America, where more attention was placed on using NG as a vehicle fuel in different countries. For instance, a high increase in the number of CNG-fueled vehicles was 
observed in Thailand, an increase of 400,000 NGVs from 2008 to 2010, where most of them were buses and cabs [80]. The lower price of natural gas, more than half of that of diesel and gasoline, contributed to NGV growth. Iran is the most significant user of natural gas in the Middle East, where the country has the second largest reserves. The growth in the number of natural-gas vehicles in Asia is due to a noticeable investment in infrastructure public-sector intervention and support programs. In Columbia, natural gas was first used in public transport, before it got attention for private cars, and the country encouraged stimulus incentives for the conversion of conventional vehicles to NGVs, which finally increased the NGV fleet from 11,500 in 2003 to 72,100 in the year 2006. Likewise, oil-producing countries encouraged the use of natural-gas vehicles to improve their oil export volume. Price reduction, allowance for the conversion from liquid-fuel vehicles to NGVs, and tax cuts were some of the measures taken by various countries, though different policies were used in many countries to encourage the usage of natural gas.

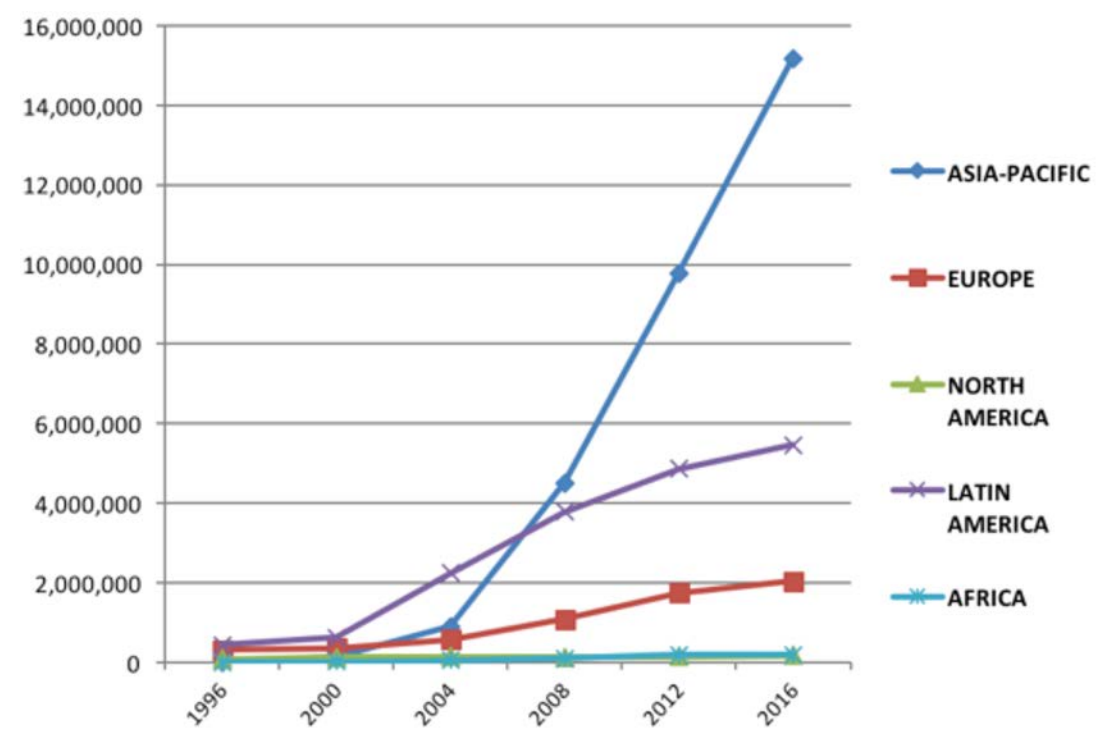

Figure 4. Natural-gas vehicles by region from 1996 to 2016 [78].

Table 4. Top 10 countries by natural-gas vehicle (NGV) population [78].

\begin{tabular}{cccc}
\hline Country & NGV Population & \% of NGVs Globally & Data Month/Year \\
\hline China & $6,080,000$ & $23.2 \%$ & January 2018 \\
Iran & $4,502,000$ & $17.2 \%$ & October 2017 \\
India & $3,090,139$ & $11.8 \%$ & March 2018 \\
Pakistan & $3,000,000$ & $11.5 \%$ & November 2016 \\
Argentina & $2,185,000$ & $8.4 \%$ & October 2016 \\
Brazil & $1,859,300$ & $7.1 \%$ & November 2015 \\
Italy & $1,004,982$ & $3.8 \%$ & March 2018 \\
Columbia & 571,668 & $2.2 \%$ & March 2018 \\
Thailand & 474,486 & $1.8 \%$ & July 2016 \\
Uzbekistan & 450,000 & $1.8 \%$ & June 2013 \\
\hline
\end{tabular}

In many countries, natural-gas conversion mainly occurs in diesel-fueled vehicles such as bus fleets and large trucking operations. It was assumed that natural gas will meet $50 \%$ of diesel demand by 2020, overtaking a 20-year diesel demand growth of 3.7\% [32]. Moreover, the price of natural gas is lower than that of diesel fuel, which would help NG take over the diesel market in the future. Small modifications in fuel injection and ignition systems can contribute to a change from conventional gasoline vehicles to natural-gas vehicles. However, the biggest problem relies on fueling infrastructure, which is considerably smaller than that for conventional fuels. 


\section{Natural-Gas Fueling Infrastructure}

The natural-gas supply system is the main feature considered when it comes to intensifying the number of natural-gas vehicles, for which refueling stations play the leading role [39]. Natural-gas refueling stations are the primary concern for users of natural-gas vehicles [85]. Fueling stations are also the main hindrance for the widespread use of natural-gas vehicles. However, a higher growth in the number of refueling stations was observed and reported. There were more than 28,955 fueling stations at the end of 2016, and a linear increase was foreseen for the coming years. The global trend in the number of natural-gas refueling stations over the last two decades is shown in Figure 5a. Higher growth was observed in the last decade, before which the number of fueling stations was quite small. With the growth in the number of NGVs, the number of fueling stations is increasing rapidly in many regions. Figure $5 b$ illustrates the number of refueling stations by region as of 2016 . The Asia-Pacific has more than 16,000 fueling stations, making it the region with most number of stations. This geographic region also saw fast growth in the number of natural-gas fueling stations. In contrast, slow growth was observed in other regions, which, in one way or another, affected the broad adoption of natural gas as a vehicle fuel. Engerer et al. [80] discussed the influence of lack of infrastructure on the growth rate of the number of NGVs in Europe as the region, except for Italy, experienced a slower growth rate in the number of NGVs during the last decade.

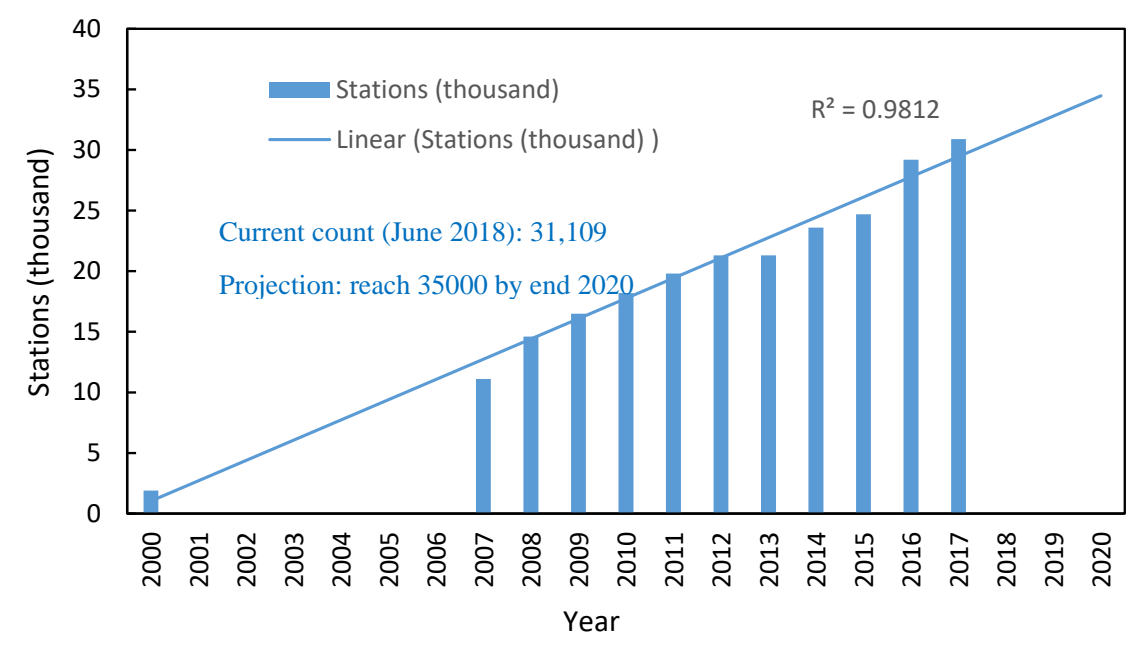

(a)

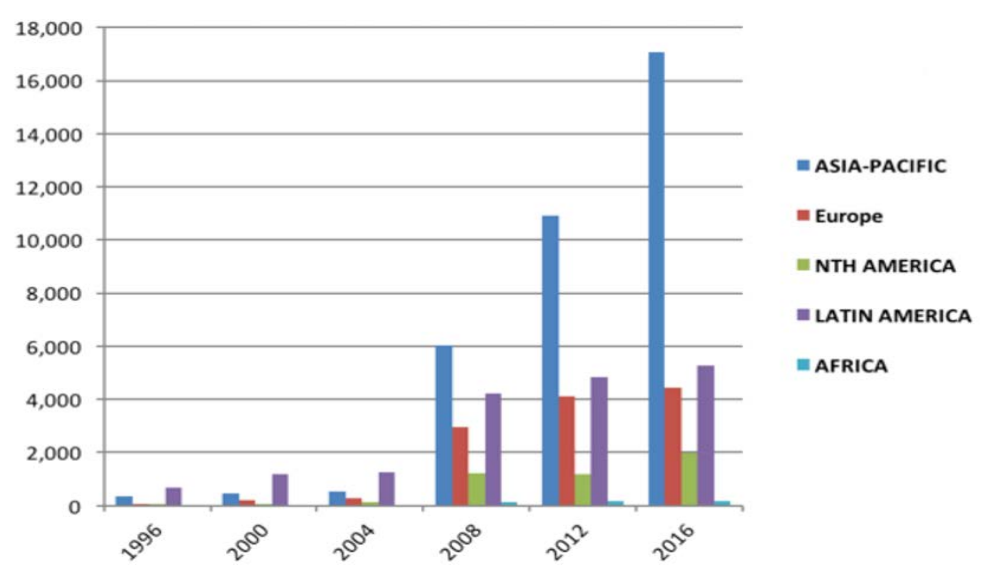

(b)

Figure 5. The number of natural-gas fueling stations: (a) worldwide and its projection; (b) growth by region [78]. 
Table 5 shows the top 10 countries in terms of refueling stations. Currently, China has the highest number of fueling stations with around 8400 reported in January 2018, with more stations undergoing construction. However, this is considerably smaller than the number of refueling stations for gasoline and diesel fuels in the country. The number of refueling stations in Pakistan represents approximately $11.5 \%$ of the total number of stations present globally, and reached over 3416 in November 2016. Semin et al. [86] highlighted the expansion of the natural-gas refueling infrastructure in Malaysia and reported a higher growth rate in the number of natural-gas vehicles in the country. Furthermore, replacing liquid fuel would reduce GHG emissions in the country. The number of vehicles per fueling station (the ratio of vehicles to fueling stations) is the main aspect to be considered when determining the expansion in the number of natural-gas vehicles. Refueling time and waiting duration are another two key issues encountered when adopting the use of natural vehicles. A number of refueling stations approximately $10-20 \%$ of that for gasoline would eliminate the refueling issues, as the price of NG is usually $40-60 \%$ lower than that of gasoline [87]. The smaller ratio of vehicles to fueling stations would also encourage automotive manufacturers to develop dedicated CNG vehicle models.

Table 5. Top 10 countries by the number of fueling stations [78].

\begin{tabular}{cccc}
\hline Country & NGV Population & Fueling Stations & Ratio of Vehicles to Stations \\
\hline China & $6,080,000$ & 8400 & 724 \\
Iran & $4,502,000$ & 2400 & 1875 \\
India & $3,090,139$ & 1424 & 2170 \\
Pakistan & $3,000,000$ & 3416 & 878 \\
Argentina & $2,185,000$ & 2014 & 1085 \\
Brazil & $1,859,300$ & 1805 & 1030 \\
Italy & $1,004,982$ & 1219 & 824 \\
Columbia & 571,668 & 813 & 703 \\
Thailand & 474,486 & 502 & 945 \\
Uzbekistan & 450,000 & 213 & 2113 \\
\hline
\end{tabular}

\subsection{Types of Refueling Station}

Similar to the vehicle performance parameters, refueling stations and services could be of importance for NG vehicle operation. There are two types of natural-gas fueling station: CNG refueling stations and liquid natural gas (LNG) refueling stations. CNG refueling stations require additional infrastructure compared to gasoline or diesel stations. This mainly includes large compressor and cooling systems to compress the gas to $24 \mathrm{MPa}$, which increases the initial construction cost of CNG stations [74]. It was reported that constructing one refueling station requires a huge amount of investment. LNG fueling stations cost twice that required for CNG fueling stations, making it a barrier for developing the infrastructure. CNG can also be filled by LNG, whereby L-CNG refueling stations are used involving gasification prior to CNG sales machines [88].

Unlike CNG refueling stations, LNG refueling stations do not require a compressor. As a result, there is less noise emission than CNG stations. Moreover, it is comparatively compact in shape and requires easier installation as the parts can also be assembled in a factory. The number of LNG refueling stations is increasing in many countries. The number of refueling stations in the US and China rose by $3 \%$ and 32\%, respectively, in the years from 2010 to 2015 [89]. Supplying LNG through LNG tankers is more economical than on-site liquefaction. CNG can also be supplied to LNG stations if there is a small-scale liquefaction plant. Arteconi et al. [69] investigated the use of LNG in vehicles, and problems existed with supply systems. It was reported that solving the limitation of refueling stations through either government subsidies or incentives could help natural gas meet the demand required by the transportation sector, and this could be achieved with limited additional investment. For instance, a European project called GasHighWay is aiming to solve refueling barriers [90]. The European commission plans on building LNG fueling stations at every $400 \mathrm{~km}$, and it is targeting to alleviate the barrier of using LNG as an alternative fuel for heavy-duty vehicles in the region [91]. 


\subsection{Natural Gas Quality}

Natural gas is non-toxic to human beings and animals. In the event of leakage, it tends to disperse into the atmosphere due to its lightweight characteristics as compared to air. If the leakage also happens in a confined space, the displacement of oxygen is expected, which may slightly affect respiration; however, its lightweight nature helps make lower points have sufficient oxygen, while displacement is only expected at the highest point. Its energy-to-carbon ratio is the high compared to other fossil fuels. Its octane number is the highest (110/130) [92] compared to diesel (92/96) and gasoline (95/98), which helps increase the compression ratio, thus leading to higher efficiency [93]. Its autoignition temperature is approximated to be $540{ }^{\circ} \mathrm{C}$, whereas it is $225^{\circ} \mathrm{C}$ for diesel. More importantly, it is insensitive to climate conditions as it does not freeze until $-165^{\circ} \mathrm{C}$. Bakar et al. [10] reviewed the advantages of CNG with vehicles regarding environmental issues. On average, there is more than $50 \%$ reduction in emissions, excluding $\mathrm{CO}_{2}$, reported with the combustion of natural gas, with almost zero little matter [11,94]. The noise level was also detected to be quite small, and natural gas further reduces noise by about -5 to -8 decibels, which improves quality of life in urban areas. It is easily incorporated with biomethane produced from biomass without modification in the engine design or infrastructure. It has higher calorific values, which, in some regions, results in it being named $\mathrm{H}$-gas referring to high-calorific gas [95].

Natural gas is mainly composed of methane with an approximate percentage of $99 \%$ [96]. In many samples, methane constitutes $92 \%$ of natural gas, whereas the remaining components are higher-level hydrocarbons and some contaminants [97,98]. A composition of methane as low as $70 \%$ can also be found in natural gas [99]. Table 6 shows the compositions of different samples of natural gas.

Table 6. Composition of natural gas in different samples [10].

\begin{tabular}{ccccc}
\hline & \multicolumn{4}{c}{ Volume Fraction (\%) } \\
\hline Composition (Formula) & Sample 1 & Sample 2 & Sample 3 & Sample 4 \\
\hline Methane $\left(\mathrm{CH}_{4}\right)$ & 94 & 92.07 & 94.39 & 91.82 \\
Ethane $\left(\mathrm{C}_{2} \mathrm{H}_{6}\right)$ & 3.3 & 4.66 & 3.29 & 2.91 \\
Propane $\left(\mathrm{C}_{3} \mathrm{H}_{8}\right)$ & 1 & 1.13 & 0.57 & Nil \\
Iso-butane $\left(\mathrm{i}-\mathrm{C}_{4} \mathrm{H}_{10}\right)$ & 0.15 & 0.21 & 0.11 & Nil \\
N-butane $\left(\mathrm{n}-\mathrm{C}_{4} \mathrm{H}_{10}\right)$ & 0.2 & 0.29 & 0.15 & Nil \\
Iso-pentane $\left(\mathrm{i}-\mathrm{C}_{5} \mathrm{H}_{12}\right)$ & 0.02 & 0.1 & 0.05 & Nil \\
N-pentane $\left(\mathrm{n}-\mathrm{C}_{5} \mathrm{H}_{12}\right)$ & 0.02 & 0.08 & 0.06 & Nil \\
Nitrogen $\left(\mathrm{N}_{2}\right)$ & 1 & 1.02 & 0.96 & 4.46 \\
Carbon dioxide $\left(\mathrm{CO}_{2}\right)$ & 0.3 & 0.26 & 0.28 & 0.81 \\
Hexane $\left(\mathrm{C}_{6}+\left(\mathrm{C}_{6} \mathrm{H}_{14}\right)\right)$ & 0.01 & 0.17 & 0.13 & Nil \\
Oxygen $\left(\mathrm{O}_{2}\right.$ & $\mathrm{Nil}$ & 0.01 & $<0.01$ & Nil \\
Carbon monoxide $(\mathrm{CO})$ & $\mathrm{Nil}$ & $<0.01$ & $<0.01$ & Nil \\
Total & 100 & 100 & 100 & 100 \\
\hline
\end{tabular}

Natural gas also receives more attention in safety, environmental, and efficiency contexts compared to conventional fuels [100]. Liu et al. [101] reported that synthetic natural gas could be used in CNG vehicles. Currently, an increase in natural-gas demand motivated higher synthetic natural-gas production.

Natural-gas properties play a significant role in gas engineering, among which density is the main property. Esfahani et al. [102] used a least-square support vector modeling approach to determine the density of natural gas. The density of natural gas was predicted as a function of molecular weight, temperature, and pressure. The model predicted the density of natural gas in pressures ranging from 1 to 690 bar, temperatures from -3.9 to $238^{\circ} \mathrm{C}$, and gas molecular weights from 16 to 130 . They observed higher effects of molecular weight on gas density compared with the consequences of pressure and temperature. Jarrahian et al. [99] illustrated the measurement of viscosity of natural gas at high temperature and pressure. They predicted the viscosity of natural gas in a wide range of temperatures 
(up to $444 \mathrm{~K}$ ), pressures (up to $138 \mathrm{MPa}$ ), and compositions, which helps during the design process of surface facilities and the management of natural gas [103]. Major effects of the molecular weight of gas on viscosity compared to pressure and temperature were also observed by Yousefi et al. [104], who developed a model that predicted the viscosity of natural gas. Another critical parameter that affects natural-gas transportation in the pipeline is the dew point, which causes condensation and pressure drop, thereby affecting transportation efficiency. Skylogianni et al. [105] developed a model to measure and predict the dew point of natural gas, so $s$ to avoids hydrocarbon condensation and increase transportation efficiency. Pezhman et al. [5] investigated the thermophysical properties of natural gas, so as to optimize natural-gas production. Table 7 shows the properties of CNG as compared to the two conventional transport fuels.

Table 7. Combustion and physical properties of compressed natural gas (CNG), diesel, and gasoline.

\begin{tabular}{|c|c|c|c|c|}
\hline \multicolumn{2}{|c|}{ Properties } & CNG & Diesel & Gasoline \\
\hline \multirow{4}{*}{ Composition, weight $\%$} & Carbon & 75.0 & $\begin{array}{c}82.5[106] \\
84-87[107]\end{array}$ & $\begin{array}{c}87.0 \\
85-88 \text { (c) [107] }\end{array}$ \\
\hline & Hydrogen & 25.0 & $\begin{array}{l}12.75[108] \\
33-16[107]\end{array}$ & $\begin{array}{c}13.0 \\
12-15[107]\end{array}$ \\
\hline & Oxygen & 0.0 & 0.0 & 0.0 \\
\hline & Nitrogen & 0.0 & 0.0 & 0.0 \\
\hline \multicolumn{2}{|c|}{ Molecular weight (g/mol) } & 16.04 & $\begin{array}{c}184.43[106] \\
\sim 200[107]\end{array}$ & $100-105$ [107] \\
\hline \multicolumn{2}{|c|}{ Density at $15^{\circ} \mathrm{C}$ and $1 \mathrm{~atm}\left(\mathrm{~kg} / \mathrm{m}^{3}\right)$ [107] } & 0.75 & $803-887$ & $719-779$ \\
\hline \multicolumn{2}{|c|}{ Specific gravity at $15^{\circ} \mathrm{C}$ and $1 \mathrm{~atm}$ [107] } & 0.424 & $0.81-0.89$ & $0.72-0.78$ \\
\hline \multirow{2}{*}{ Stoichiometric air-fuel ratio } & Molar Basis & 9.7 & $50.03^{1}$ & $59.5^{2}$ \\
\hline & Mass Basis [107] & 17.2 & 14.7 & 14.7 \\
\hline \multicolumn{2}{|c|}{ Stoichiometric volume occupation in cylinder, $\%$} & 9.35 & $\mathrm{~N} / \mathrm{A}$ & $2^{3}$ \\
\hline \multirow{2}{*}{ Lower calorific value } & $\mathrm{MJ} / \mathrm{Nm}^{3}$ & 38.0 & 36,046 & 32,317 \\
\hline & $\mathrm{MJ} / \mathrm{kg}$ & 47.1 & 44.41 & 42.9 \\
\hline \multirow{2}{*}{$\begin{array}{l}\text { Stoichiometric mixture energy } \\
\text { density }\left(\mathrm{MJ} / \mathrm{Nm}^{3}\right)\end{array}$} & Mixture aspirated & 2.9 & $3.61^{4}$ & $3.55^{5}$ \\
\hline & Air Aspirated & 3.60 & $\mathrm{~N} / \mathrm{A}$ & $\mathrm{N} / \mathrm{A}$ \\
\hline \multirow{2}{*}{$\begin{array}{l}\text { Flammability limit, \% vol. of fuel } \\
\text { in air [107] }\end{array}$} & Lower & 5.3 & 1 & 1.4 \\
\hline & Higher & 15.0 & 6 & 7.6 \\
\hline \multicolumn{2}{|c|}{ Laminar flame velocity $(\mathrm{cm} / \mathrm{s})$} & $38[11]$ & 82.17 [109] & $48.93[110]$ \\
\hline \multicolumn{2}{|c|}{ Latent heat of vaporization at $15^{\circ} \mathrm{C}, \mathrm{MJ} / \mathrm{Nm}^{3}$ [107] } & $\mathrm{N} / \mathrm{A}$ & 26.08 & 33.5 \\
\hline \multicolumn{2}{|c|}{ Latent heat of vaporization at $15^{\circ} \mathrm{C}, \mathrm{MJ} / \mathrm{kg}$ [107] } & $\mathrm{N} / \mathrm{A}$ & 0.233 & 0.35 \\
\hline \multicolumn{2}{|c|}{ Theoretical adiabatic flame temperature, $\mathrm{K}$} & 2220 & $2300-2350$ [111] & 2411 \\
\hline \multicolumn{2}{|c|}{ Autoignition temperature, K [107] } & 813.15 & 588.7 & 530.37 \\
\hline \multirow{3}{*}{ Octane number [107] } & Research octane number (R) & $>127[112]$ & $\mathrm{N} / \mathrm{A}$ & $90-100$ \\
\hline & Motor octane number (M) & $122[112]$ & $\mathrm{N} / \mathrm{A}$ & $81-90$ \\
\hline & Mean $((\mathrm{R}+\mathrm{M}) / 2)$ & $\mathrm{N} / \mathrm{A}$ & $\mathrm{N} / \mathrm{A}$ & $86-94$ \\
\hline \multicolumn{2}{|c|}{ Cetane number [107] } & $\mathrm{N} / \mathrm{A}$ & $40-55$ & $5-20$ \\
\hline \multicolumn{2}{|c|}{ Minimum ignition energy in air, MJ [113] } & 0.285 & 0.243 & 0.243 \\
\hline \multicolumn{2}{|c|}{ Storage pressure, $\mathrm{MPa}$} & 20.6 & 0.1 & 0.1 \\
\hline \multicolumn{2}{|c|}{ Boiling point (atmospheric pressure), ${ }^{\circ} \mathrm{C}$} & -162 & $250-350$ & $35-200$ \\
\hline
\end{tabular}

${ }^{1}$ Calculated from diesel fuel with $86.5 \% \mathrm{C}$ and $13.25 \% \mathrm{H} .{ }^{2}$ Calculated from gasoline with $\mathrm{C}_{8} \mathrm{H}_{18} .{ }^{3} \mathrm{Volume}$
percentage of fuel in vaporized stoichiometric mixture [107]. ${ }^{4}$ Heating value of stoichiometric mixture, a mixture in
vapor state [107]. ${ }^{5}$ Heating value of stoichiometric mixture, a mixture in vapor state [107].

\subsection{Fuel Treatment and Distribution}

The transmission of natural gas through pipelines is one of the major challenges for the popular utilization of NGVs. The presence of carbon dioxide and hydrogen sulfide along with water forms an acidic solution, which is very corrosive and leads to severe damage in the pipelines, and hence, leakage of the natural gas. The presence of water, on the other hand, would cause slug flow following condensation 
in pipelines. As high as $70 \% \mathrm{CO}_{2}$ could be present in some natural-gas fields. Therefore, it is necessary to remove some acidic gas prior to transportation to meet pipeline specifications of $2-3 \% \mathrm{CO}_{2}$ or not more than $50 \mathrm{ppm} \mathrm{CO}_{2}$ in LNG production. By removing the acidic gases, the gas volume reduces, and the sold gas stream calorific value can be increased [114]. Currently, there are some mechanisms to remove these acidic gases via sweetening technologies to prevent corrosion. The utilization of these technologies depends on natural-gas feed conditions, size and location of natural-gas treatment plants, plant economics, ambient conditions, process control, and environmental aspects [115].

There are some mechanisms that are popular in this area, such as physical and chemical absorption, membrane separation, and low-temperature separation. The most suitable process for the removal of $\mathrm{CO}_{2}$ from LNG is low-temperature separation as the distillation temperature for the gaseous products and dehydration is achieved. Moreover, $\mathrm{CO}_{2}$ can be solidified and removed at a temperature below its solidification temperature, and achieves a higher degree of fractionation by adding additives. Membrane processes are also another eco-friendly alternative with little loss of amine solution. The most common membrane used is cellulose acetate, and the process depends on the gas components, membrane material, and the process conditions [116]. This technology is able to remove chemical species without phase change, and requires low thermal energy and simple process flow [117]. Membrane technology is normally used for purification and desalination of water, and is widely used to remove carbon dioxide, nitrogen, and hydrogen sulfide, which is highly toxic and corrosive. Higher compression-gas pressure is also required to overcome the hydrodynamic resistance caused by the permeation of acidic gases through nanoscale pores [118]. In the amine absorption process, the crude natural gas enters the separator in order to remove the free liquid prior to entering the absorber. The lean amine solution then enters the absorber and reacts with acidic gases and dissolves in the liquid phase. The acidic gas stream is cooled and flashed back to recapture water, which is then flowed back into the regeneration column to prevent water loss. However, the disadvantages of this process are the occurrence of corrosion during absorption, degradation when oxygen combines with amine solutions, and foaming due to condensed hydrocarbons, suspended solids, and other impurities [119].

Furthermore, inorganic solvents in carbonate-based absorption can chemically absorb $\mathrm{CO}_{2}$. The process is regenerable, requiring low desorption energy; however, it has a lower rate of carbon-dioxide absorption that can be enhanced by adding piperazine. In addition, the gas stream can also be passed through trays with caustic solution in sodium-hydroxide-based absorption. The $\mathrm{CO}_{2}$ forms a non-regenerable solution $\left(\mathrm{Na}_{2} \mathrm{CO}_{3}\right)$ that must be removed in the process. The liquid desiccant absorption process (physical or chemical) is the most common technology used in the removal of acidic gases from natural gas worldwide. The acidic gas reacts with aqueous alkaline amine solution, and hence, purifies the processed gas. This process is mainly enhanced by lower temperatures, higher amine concentrations, and circulation rate. Furthermore, solid desiccant adsorption processes can handle lower gas-processing capacities. Its working principle involve either adhesive force or a chemical process [118].

The production of natural gas can be increased; however, the ability to distribute to the end user needs significant attention and consideration. The distribution of natural gas is one of the concerns. Natural gas can be transported to refueling stations either via pipeline or LNG tanker. The transportation of NG is mainly performed via underground pipeline to minimize the harmful effects [95]. Pipelines are an efficient way of transporting natural gas [120]. The transportation of natural gas via pipelines is common, which reduces the cost of liquefying the natural gas, and also reduces the transportation risk on the road [121]. Moreover, liquefaction requires advanced technology. Pipelines are generally the main pathways for transporting natural gas domestically and across countries [122]. To fulfill the increasing number of vehicles run by natural gas, there are many pipelines under construction in many regions. Recently, a higher growth in the number of pipelines was also observed worldwide. For instance, the overall length of China's pipelines reached $50,000 \mathrm{~km}$ from 16,000 km in ten years, and is expected to reach 100,000 km in 2020. Different policies are also in effect to boost the distribution line, and a higher pipeline utilization rate would help meet increasing natural-gas demands [123]. 
Distribution systems play a significant role for natural gas to be widely used. Natural gas can also be transported as LNG. LNG involves the use of a liquefaction plant to convert gas into a liquid phase, after which it is stored in a cryogenic tank at $-160^{\circ} \mathrm{C}$ [124-126]. LNG transportation is frequent in many regions [127]. Three-quarters of Asia's imported natural gas is as LNG, 50\% of which belongs to Japan [128]. LNG imports are also increasing in Europe. Dorigoni et al. [129] predicted a tremendous increase in natural-gas usage in Europe by 2025 and compared the effectiveness of LNG imports, where the current LNG cost is higher than that of pipeline transport. However, their model also predicted a lower LNG price than that of pipeline gas if liquefaction, transportation, and regasification costs could be reduced in the future. The increase in LNG infrastructure across Europe was also reported in another study [130].

Currently, though there is a huge supply of natural gas from unconventional reserves, liquefaction facilities hinder the export capacity [131]. Wang et al. [132] studied the potential of natural-gas transport in Asia. They reported that pipelines carry $70 \%$ of the natural gas, and the remaining $30 \%$ is transported as LNG. CNG pipelines are mentioned as not being a good option for long-term utilization. As such, LNG could be considered a better option. However, this depends on the market demand and consumption capacity. It was reported that transporting natural gas in pipelines is more efficient [133]. For unforeseen circumstances and problems in pipelines, LNG is a better consideration, and its usage recently increased $[134,135]$. This diversification could potentially minimize issues related to supply [136]. Similarly, natural-gas storage plays a significant role in the development of NG vehicles. As the global consumption of NG increases, constructing a bigger storage system is required to alleviate deficiency issues, especially during times of peak demand.

Table 8 shows LNG and pipeline shares in the global gas market. The LNG share in the global gas trade market is increasing and was forecasted to overtake that of pipelines after 2020, resulting in an increase in the number of LNG vehicles. Wang et al. [137] proposed that there would be a dramatic growth in the number of LNG vehicles in China. A higher rate of LNG export from the US as a result of shale-gas production was forecasted $[138,139]$. The distribution phase is one of the main bottlenecks for LNG vehicles, though the technology of refueling, storage, and burning are well established. Two methods can be used to supply LNG to the refueling station. The first method is through purchase at regasification terminals, which depend on distance, and it was found not to be economical for very long distances, as heat can change the liquid to gas. The second method is through liquefaction on site [69]. For long distances, the latter might be an economical and feasible option; however, the main issue involves the availability of small-scale liquefaction.

Table 8. Liquid natural gas (LNG) and pipeline shares on the global gas trade market, adapted from Reference [140].

\begin{tabular}{cccc}
\hline \multirow{2}{*}{ Natural Gas Transport Type } & \multicolumn{3}{c}{ Year } \\
\cline { 2 - 4 } & $\mathbf{2 0 0 0}$ & $\mathbf{2 0 1 5}$ & $\mathbf{2 0 4 0}$ \\
\hline LNG & $26 \%$ & $40 \%$ & $53 \%$ \\
Pipeline & $74 \%$ & $60 \%$ & $47 \%$ \\
Total (tcm) & 525 & 695 & 1150 \\
\hline
\end{tabular}

\subsection{Fuel Storage and Range}

The storage of natural gas raises some disadvantages compared to liquid fuel, as it is in gaseous form at standard temperature and pressure conditions. The energy content per unit volume (storage energy) of natural gas is lower than liquid fuels. Natural gas can be made ready for use in vehicles in two forms: compressed natural gas (CNG) and liquid natural gas (LNG). LNG and CNG both indicate the stored forms of natural gas [141,142]. Most natural-gas vehicles worldwide operate with CNG as opposed to LNG [4]. Anderson et al. [39] illustrated that liquefying natural gas is an option to consider for enhancing the performance of natural gas, which lacks initial energy content in 
its normal condition. LNG was found to result in a similar performance to that of diesel-fueled engines, and as a result, it was found attractive for heavy-duty vehicles. A cryogenic tank is required to store LNG at $-165^{\circ} \mathrm{C}$. Another option of restraining natural gas to an adequate size is by compressing it to 20-22 MPa, which reduces its standard gaseous volume 100-fold. Pressurizing the CNG in a sealed storage container increases the energy density closer to that of liquid fuels. By doing so, it reduces the need for a larger tank in the car. Compressing the gas to the level mentioned above requires a hard certified tank, such as one made from steel or carbon fiber. Moreover, testing every five years is required to reduce accidents caused by cylinders. As the energy density of natural gas is $25 \%$ lower than that of gasoline, the tank usually takes up more space in the trunk of vehicles. The compression of natural gas, therefore, alleviates the issue of spacing in vehicles. It was reported that space problems in small vehicles is no longer an issue as small fuel tanks are suitable for storage in small vehicles [143]. CNG fuel characteristics are listed in Table 7.

Table 9 shows differences between CNG and LNG. LNG vehicles (1\% of the total number of vehicles) are lesser in number compared to CNG vehicles (5\% of the total number of vehicles). Hao et al. [84] reported that China started using LNG as vehicle fuels in 2009, whereas CNG was widely used beforehand. Eighty percent of CNG vehicles were modified from gasoline-fueled vehicles, while $20 \%$ were initially manufactured as CNG vehicles due to consumer cost contemplation. Modifications involve the installation of a CNG tank and an engine retrofit. Modified CNG vehicles were found to be more attractive than manufactured CNG vehicles as the follow-up costs were higher in the case of the latter. For LNG vehicles, $70 \%$ were heavy-duty transports (HDTs), and the other $30 \%$ were buses. Comparatively, LNG vehicles are more expensive (20\% higher than diesel), typically due to the cost incurred by LNG tanks.

Table 9. Differences between compressed natural gas (CNG) and LNG [132].

\begin{tabular}{ccc}
\hline Properties & CNG & LNG \\
\hline Fluid state & Gas & Liquid \\
Pressure & 100 to 250 bar & 1 bar \\
Temperature & $30{ }^{\circ} \mathrm{C}$ to $-40{ }^{\circ} \mathrm{C}$ & $-16{ }^{\circ} \mathrm{C}$ \\
Loading & Dehydrate, compress & Treat, liquefy, store \\
Loading/Offloading & Gas under pressure & As liquid \\
Compression Ratio & $\sim 250-350: 1$ & $\sim 600 / 1$ \\
Containment D/t & $\sim 25$ to 60 & $\sim 1000$ \\
Material & Fine-grain normalized C-Mn steel, & Aluminum, Stainless, Ni Steel \\
\hline
\end{tabular}

Storage capacity plays a significant role in the range of $\mathrm{CNG}$ vehicles. CNG vehicles have reduced driving distance, typically between 150 and $200 \mathrm{~km}$, and the gas tank takes $10-20 \%$ of the luggage space. Upon replacing gasoline engines, CNG vehicles must cover a minimum range of $450 \mathrm{~km}$, compensating for the coverage range of gasoline vehicles between $450 \mathrm{~km}$ and $800 \mathrm{~km}$ with a storage capacity of 45 to $110 \mathrm{~L}$ [85]. The storage capacity and pressure determines the range of vehicles following the optimization of engine efficiency. The pressure at the filling station of CNG is usually $24 \mathrm{MPa}$ [144]. To achieve the range mentioned above, the storage capacity needs to be in the range of 170 to $280 \mathrm{~L}$, which is almost three times that of the average of its gasoline counterpart, thereby reducing space for passengers and cargo. Moreover, the storage tank should also withstand mechanical damage due to accidents, and external degradation due to environmental conditions, including heat.

CNG vehicles still currently lack individual consumer market penetration. Decreased range, the reduced number of refueling stations, purchasing price, and difficulties during servicing are some of the barriers for adopting CNG as a vehicle fuel [39]. The purchasing price is higher for CNG than for gasoline. For example, the price for a Honda Civic was 18,500 USD for gasoline, while it was USD 26, 500 for a factory CNG vehicle. The lower cost of fuel is believed to offset the initial purchase price of the vehicle, and this is more feasible in a larger fleet, as there would be bulk purchase 
sharing refueling and maintenance facilities. CNG does require modification when used in gasoline engines. Converting gasoline vehicles to CNGVs is technically possible by separately fitting a fuel supply system and injecting into the same cylinder. It can also be used in a diesel engine with small modifications. However, the theoretical performance of CNG may not be achieved, as engine internals have some effects. The simpler conversion of conventional vehicles into CNG vehicles augmented the number of natural-gas vehicles by $2.5 \%$ per year over the last four decades in different vehicle types, including light or heavy vehicles, commercial trucks, street sweepers, trains, and buses. A significant regulator is required when delivering CNG from storage to four-stroke engines, and a gas injector assisted by a metering valve is also needed for injecting gas into the combustion chamber.

\subsection{Natural Gas from Other Sources (Renewable CNG and Biomethane)}

In addition to the promising reserves and relatively low prices, some countries also decided to produce biomethane for transportation to avoid potential problems related to supply to the international market. This is widely practiced in some regions in an effort to tackle energy and supply security caused by geopolitical pressure and instability, and as a result, the use of biogas in different parts of the world is estimated to double current production in 2022 [145]. Biogas is produced via anaerobic digestion, which is a biochemical conversion mechanism of biomass into useful fuel. The process involves the digestion of human, animal, and plant waste with anaerobic organisms in the absence of oxygen in the digester [146,147]. Biogas can also be produced via anaerobic fermentation in landfill, which is referred to as landfill gas. There are three main stages in biogas production: hydrolysis, acidification, and methane formation. Consequently, the product contains methane in prime amounts ranging from $50 \%$ to $60 \%$, while the remainder is mostly composed of $\mathrm{CO}_{2}$ comprising $30 \%$ to $40 \%$. It has a small amount of other impurities including water, albeit not exceeding $4 \%$. As the methane content in biogas is high, it can be directly used for heat and electricity generation. However, as the methane concentration determines the energy content, upgrading to a higher proportion of methane, called biomethane, is vital for its application as a transport fuel. Upgrading biogas to biomethane removes $\mathrm{CO}_{2}$, which purifies the gas and constitutes its energy content as a fossil-fuel-derived natural gas. Biomethane production was reported to be suitable for different engine modes, and its share in the transportation sector is estimated to reach $27 \%$ by 2050 from a $2 \%$ share at present [148]. Moreover, it was found that the application of biomethane in the transportation sector is as economically competitive as heat and electricity generation from biogas [149].

Membrane separation, chemical and physical absorption, pressure swing adsorption (PSA), and cryogenic processes are some recent technologies being used to upgrade biogas to biomethane. In conjunction with these technologies, a prior stage is required to remove or reduce other impurities including $\mathrm{H}_{2} \mathrm{O}$, siloxanes, and $\mathrm{H}_{2} \mathrm{~S}$. Absorption relies on the solubility of compositions in the biogas. As $\mathrm{CO}_{2}$ is more soluble than $\mathrm{CH}_{4}$, it can be separated via absorption, which can be categorized into high-pressure water scrubbing, organic physical scrubbing, and chemical scrubbing. The category is based on the solvent used for the absorption process. Water is used as the solvent in water scrubbing, organic solvents, such as selexol, are used in organic physical scrubbing for dissolving purposes, while chemical scrubbing uses chemicals to absorb and chemically react with $\mathrm{CO}_{2}$ [148]. In pressure swing adsorption, $\mathrm{CO}_{2}$ due to its lower molecular size compared to $\mathrm{CH}_{4}$ can be removed into the adsorbent material using elevated pressure and separated from $\mathrm{CH}_{4}$. Regeneration processes would then help remove the adsorbed $\mathrm{CO}_{2}$ by applying lower pressure [150]. Currently, membrane separation has a larger market due to its economic benefits. The principle of cryogenic separation mainly arises from different boiling temperatures of $\mathrm{CO}_{2}\left(-78.2^{\circ} \mathrm{C}\right)$ and methane $\left(-161.5^{\circ} \mathrm{C}\right)$ at $1 \mathrm{bar}$; thus, the separation of the two gases can be achieved while liquefying [151]. Biomethane with above $95 \%$ methane content was achieved using these technologies, which is then suitable to be used as vehicular fuel.

There is a recent initiative of producing methane through power to a gas solution in view of storing excess renewable electricity [152], $\mathrm{CO}_{2}$ capture, and flue gas treatment [153]. Methane can be produced through this solution in two steps. A surplus of electricity is supplied to the electrolysis process where high-temperature steam is injected, and oxygen and hydrogen are separated. 
Hydrogen is then combined with carbon dioxide in a methanation reaction. The technological, economic, and environmental feasibility of such an initiative is still under investigation. The methane produced from this process is another potential alternative fuel for internal combustion engines.

\section{Natural-Gas Engines and Their Limitations}

Since the 1940s, natural gas has been used as a source of energy for heat and electricity, and as a raw material in the chemical industry. In the transportation sector, it has been used to fuel vehicles for decades. This was intensified in the last two decades due to the mass production of lightweight high-pressure storage cylinders [11]. However, the market share of natural-gas vehicles is low, amounting to only 15.2 million of the 1.2 billion total vehicles [6]. This is in contrast to the multifaceted benefits of the fuel and its abundant availability. Even though research shows a growing trend in the market share of natural-gas vehicles in the next 20 years, with an annual growth of 5-7\% pushing the market share to 35 million in 2025 [7], natural gas is far below the capacity of replacing other fuels in transportation sector. This section presents the types of engine using natural gas as a source of energy, and their limitations. Natural gas is commonly used in automotive vehicles with two methods of fueling, compressed natural gas (CNG) and liquid natural gas (LNG). Details of these two fuels are stated in Section 3, Table 9. This section focuses on CNG-powered engines and their limitations.

CNG is most commonly utilized in spark-ignition (SI) engines. This is due to the higher autoignition temperature, as shown in Table 7, requiring higher ignition energy only attainable through a spark. In recent studies, there were efforts to utilize CNG as a diesel substitution in compression-ignition (CI) engines in a dual-fueling mode. This was mainly motivated by the higher emissions of particulate matter (PM) and nitrogen oxides (NOx) in diesel-fueled compression-ignition engines. Figure 6 shows the various combustion modes for CNG in internal combustion (IC) engines [154]. The utilization of CNG in compression-ignition (CI), dual-fueling compression-ignition (DFCI), and homogeneous-charge compression-ignition (HCCI) engines, along with their recent progress, is the focus of a separate review. The current work focuses on the utilization of natural gas in spark-ignition engines and its technological and operational challenges. The latest advancements in research and development using CNG in diesel engines is also briefly discussed.

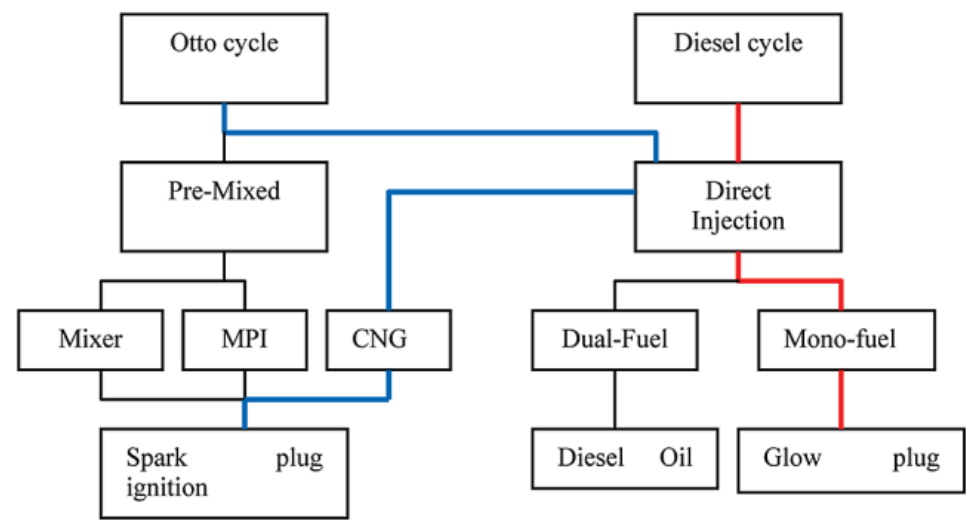

Figure 6. Combustion modes for compressed natural gas (CNG) in internal combustion (IC) engines [154].

The ignition and flame initiation process of an SI engine should be discussed in detail for a better picture of the combustion phenomenon of both liquid and gaseous fuels. In an SI engine, combustion is initiated by a spark discharge, which is imposed by an electrical ignition system. The initiation and formation of a self-sustaining flame kernel in the combustion of such an engine comprise complex processes that can have many phases. These stages are categorized as pre-breakdown, and the plasma and initial combustion phases [155-157]. The fundamental requirements for the ignition system are to create a self-sustaining flame kernel to have enough voltage to break the gap resistance between the electrodes. The ignition system should have enough energy-storage capacity to create a sufficiently 
sized ignition kernel, and there should be a sufficient duration of voltage release [155]. The minimum ignition energy required by different fuels in air varies. As shown in Table 7, the minimum ignition energy required by $\mathrm{CNG}$ is higher than that of gasoline. The required minimum energy of ignition systems can be the function of an equivalence ratio $(\varphi)$. For a lean local air/fuel mixture, the required minimum ignition energy can be higher. The mixture $\varphi$ does not directly affect the initial plasma kernel; however, the inflammation process and thickness are significantly affected by the local $\varphi$. Hence, a lean mixture demands a larger plasma kernel before inflammation becomes apparent. The work of Aleiferis et al. [158] also showed that, for a given spark energy, the longest discharge duration produced the highest initial flame-kernel growth rate.

The regular combustion process of SI engine can be categorized into three distinct phases according to the energy release and fuel burn rate as shown in Figure $7 \mathrm{a}, \mathrm{b}$, and as discussed in Reference [155]. The first phase is the flame development process, during which a small fraction of fuel is burned (up to $10 \%$ ). The flame size in this phase, especially in the early stages, is tiny and highly influenced by the turbulent flow surrounding it, by the $\varphi$ of the mixture, and by heat transfer due to early flame contact with spark electrodes. The turbulent flame then propagates at a fast rate until the combustion chamber limits its expansion. Up to $90 \%$ of the total fuel energy is released at the end of the fast-burning phase [155]. The process ends with the completion phase, which can be long or unable to achieve a complete combustion depending on the $\varphi$ of the mixture and other factors.

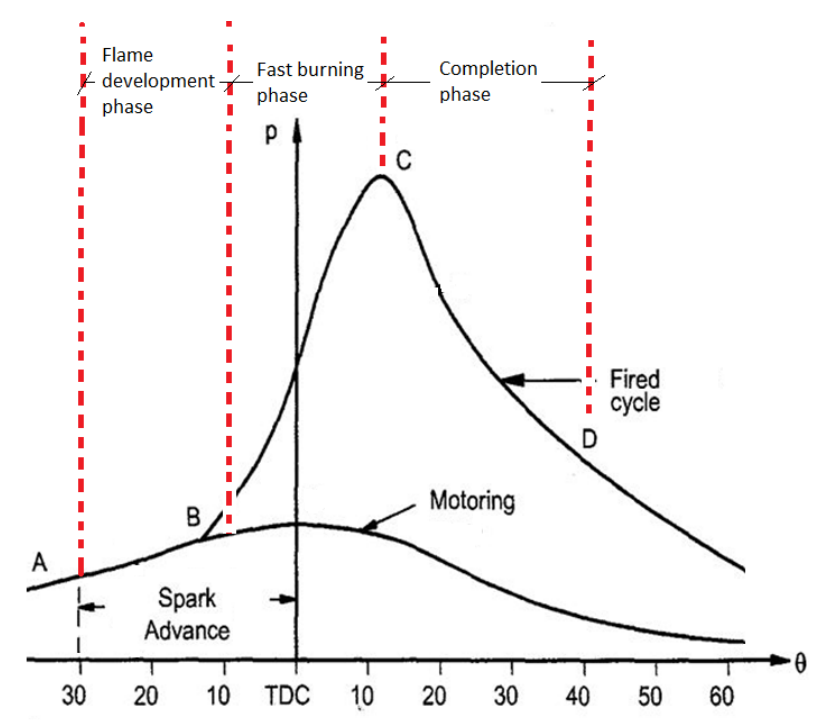

(a)

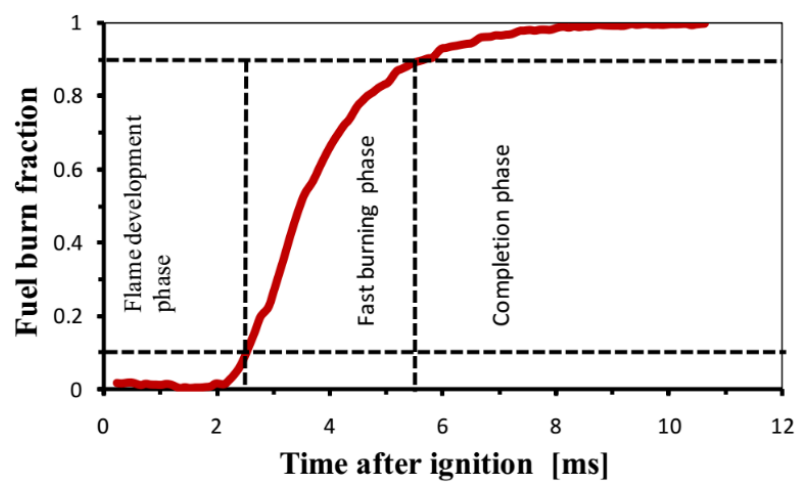

(b)

Figure 7. Spark-ignition (SI) engine combustion stages: (a) combustion pressure versus crank angle; (b) burn fraction of a homogeneous CNG combustion [159]. 
The performance parameters that affect the combustion of fuels in SI engines are the $\varphi$ or its inversely proportional air-fuel ratio $(\lambda)$. It increases along with the ratio of the actual fuel-air ratio to the chemically correct (stoichiometric) fuel-air ratio. Accordingly, mixtures can be lean $(\varphi<1)$, rich $(\varphi>1)$, or chemically correct (stoichiometric) $(\varphi=1)$. The ratio of the total volume (also known as maximum cylinder volume) to the clearance volume (minimum volume) of the engine cylinder is defined as the compression ratio $(\gamma)$. The compression ratio is an influential parameter in both spark-ignition and compression-ignition engines, heavily affecting thermal efficiency. Even though thermal efficiency increases with an increase in compression ratio for both spark- and compression-ignition engines, the typical $\gamma$ for a gasoline engine is traditionally limited to the range of 8-11, and 12-23 for a diesel engine. With an increase in the $\gamma$ of an SI engine, the temperature of the air-fuel mixture rises above the autoignition temperature of the fuel-in-air mixture, leading to knock and surface pre-ignition. The compression ratio of diesel engines, however, is limited by the strength of the engine cylinder and the engine block material.

A proper understanding of the thermodynamic process of internal combustion engines depends on the accuracy of experimental work. Pressure and temperature measurement are the most common tools to analyze the combustion process that can be obtained through experiment. Other experimental observations need complicated and expensive measurement systems and devices, such as flame imaging, to understand the development, in-cylinder flow, spray behavior, and mixture distribution. The most widely used equipment to measure the combustion pressure is a pressure transducer that enables the study of pressure variation throughout the cycle. Observations and detailed analysis of pressure readings from a pressure transducer are utilized to gather further information about the rate of heat release (HRR), indicated mean effective pressure (IMEP), mass fraction burn (MFB), and combustion efficiency. In-cylinder pressure $(P)$ is usually presented against degree crank angle $(C A D)$ or cylinder volume $(V)$. The pressure is built during the compression stroke (also called motoring pressure) and increases drastically due to the combustion process (also known as combustion pressure). It then drops as soon as the expansion stroke starts, and the built-up pressure is transformed into mechanical power, before the exhaust valve opens.

The area inside the cycle is considered IMEP. IMEP is defined as the average pressure exerted on the piston head during the working cycle developed by the combustion. The pressure difference between the pressure developed during the motoring cycle and the pressure generated during the working cycle is defined as the pressure built by the combustion process, used to calculate the heat released from the combustion.

\subsection{CNG in Spark-Ignition Engines}

Gasoline is used in spark-ignition engines. The transportation sector is currently under close surveillance due to an increase in emissions of $\mathrm{CO}_{2}, \mathrm{CO}$, hydrocarbon (HC), and NOx from the exhaust tail of these engines. Even though liquid fuels have advantages over their gaseous counterparts, such as a higher calorific value [160], ease of storage and transportation, and requiring smaller combustion chamber volumes, they are under scrutiny due to the gaseous emissions, as stated above. From Table 7 , it can be seen that CNG as a fuel has a lower carbon content compared to its gasoline counterpart, leading to lower emissions of $\mathrm{CO}_{2}$ in addition the fact that $\mathrm{CNG}$ is utilized in an air-tight fueling system. The evaporative emissions from CNG are minimal compared to those of liquid fuels used in SI engines. Likewise, gaseous fuels such as CNG take a brief time to fully atomize with the air. On the other hand, liquid fuels need more time for the air-fuel atomization. This is due to extra time required for the evaporation of spray droplets (physical delay). As a result, liquid fuels emit more HCs, especially with an increase in engine speed. It is said that CNG/LNG vehicles emit 10-20\% lower GHGs compared to gasoline vehicles [161]. 


\subsubsection{Mixture-Aspirated SI Engine}

The supply of air-fuel ratio in spark-ignition engines is either via a carburetor, old technology, or through a fuel-injection system [162]. In the carburetor system, a mixture of air and fuel proportionated by the pressure difference in the venturi of the carburetor is inducted into the combustion chamber [163]. On the other hand, air alone enters through the inlet manifold and fuel is injected into the port or directly into the combustion chamber in the injection system [162]. The carburetor is completely replaced by a mixing chamber where CNG and air are mixed [164]. These types of engines are retrofitted from carburetor-type gasoline-fueled spark-ignition engines to use CNG. Such engines may operate as dual-fuel arrangements, where a CNG mixing chamber is installed after the carburetor, which is controlled by a solenoid switch valve. Since the engine is designed for liquid gasoline, it has a lower compression ratio. This is because of gasoline having a lower octane rating compared to CNG.

Table 7 shows the octane rating comparison of CNG and gasoline. When CNG is fueled in a retrofitted gasoline engine, the combustion efficiency drops and combustion stability is highly compromised. Jahirul et al. [165] reported a 19.25\% reduction in brake power and $15.96 \%$ reduction in brake-specific fuel consumption (BSFC) at 50\% throttle position for the speed range of 1500-5500 rpm. A 15.5\% reduction in brake power and 9\% reduction in BSFC were also reported by Rezapour et al., as shown in Figure 8 [166]. Moreover, fueling CNG in a retrofitted SI engine requires modifications to the ignition system, valve trains, storage, and fueling system. Such limitations are addressed when using diesel engines for a retrofitted CNG engine in SI engine mode, thereby allowing a high-compression-ratio combustion chamber to be attained [167]. A comparative analysis of CNG and gasoline on such retrofitted engines could not be found in the literature as base data for such engines are available only with diesel fuel.

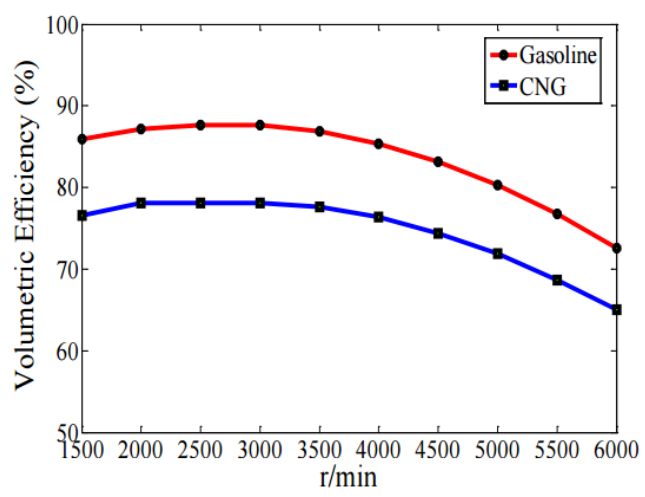

(a)

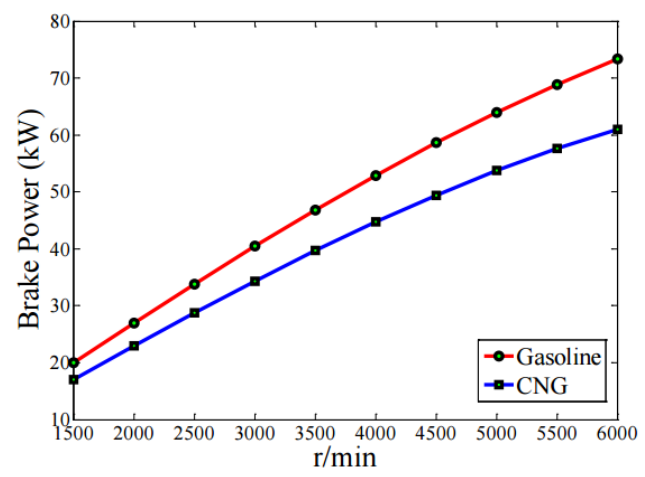

(c)

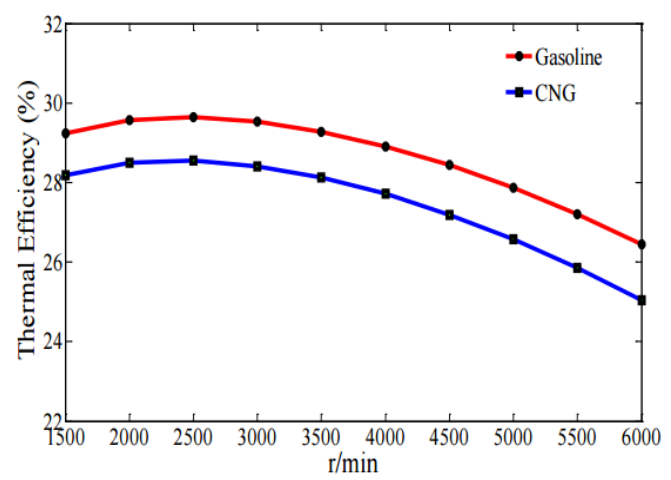

(b)

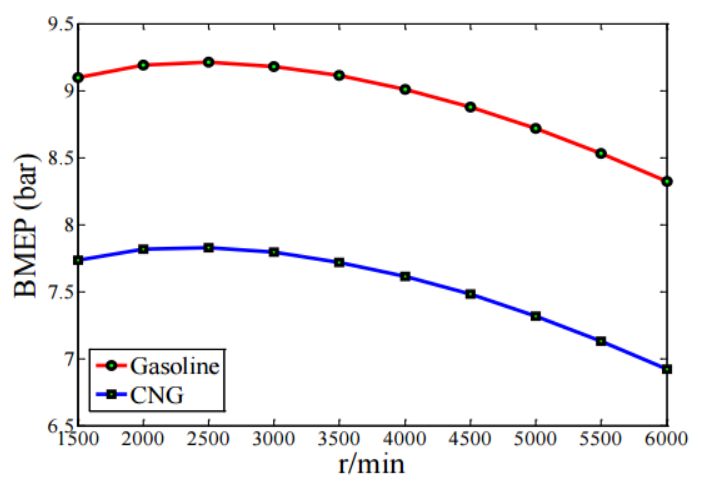

(d)

Figure 8. Performance comparison of $\mathrm{CNG}$ and gasoline in a retrofitted dual-fuel gasoline engine: (a) volumetric efficiency; (b) thermal efficiency; (c) brake power; (d) brake mean effective pressure (BMEP) [166]. 
In regular service, natural-gas engines consume 25-35\% more energy than their diesel counterparts [168]. Engines retrofitted from diesel engines for CNG fueling can only be operated in mono-fuel operation, as fueling gasoline in such engines leads to severe knock and other operation hurdles. The high compression ratio of an engine retrofitted from diesel results in higher NOx emissions $[169,170]$. In addition to the issue of the compression ratio, as CNG displaces the air during the fuel-air mixing, there is an enormous compromise in the volumetric efficiency in the carbureted and indirect-injection fueling systems [11,171-174]. Specifically, in the carburetor system, there is air restriction due to the throttling effect. Therefore, the application of CNG in a mixture-aspirated SI engine is coupled with engine performance reduction. It was reported that natural gas gives $10 \%$ lower power output compared to equivalent gasoline-fueled vehicles [175-177]. On top of this, the precision of controlling the air-fuel mixture through a carburetor system was in question for a longer period. Adding electronic components did not show improvement; rather, the construction of such a system proved to be challenging [178]. It was at this point that the fuel-injection system was adopted from the compression-ignition engine fueling system. There are other mechanisms which improve the performance of CNG-fueled engine with a direct-injection (DI) fueling system, discussed in detail in the next section.

\subsubsection{Spark-Ignition Direct-Injection Engines}

Fuel delivery systems have seen various changes throughout the years, and recently incorporated advanced technologies. The development of fuel delivery started from a conventional carburetor system before arriving at the recent DI system. The limitations of a carburetor system are discussed in Section 4.1.1, and are examined further in References $[179,180]$. In the fuel-injection technology, fuel-and-air mixing is performed by forcing the fuel through a narrow nozzle with the help of high pumping pressure. The fuel injection system for SI engines is broadly classified as direct and indirect injection. The direct-injection system injects the fuel at high pressure directly into the combustion chamber, while, in the indirect-injection system (port-injection, manifold-injection, and multipoint fuel-injection systems), the fuel injector delivers fuel at some point near the combustion chamber. All indirect-injection systems like the carburetor fueling system have performance loss issues when they are fueled with gaseous fuels. The fuel-injection design would avoid problems related to balancing multiple carburetors and would gain even distribution in the inlet manifold. Some advantages of the fuel-injection system involve higher volumetric efficiency, high precision with air-fuel mixture control, and thereby, a better response to change, better fuel distribution and atomization, ability to integrate with feedback control, and the use of greater overlap [181]. Furthermore, the introduction of post-combustion control of emissions, such as catalytic converters and oxygen sensors, demanded a closed-loop control system and precise metering of the fuel-air mixture [182]. Electronic fuel injection systems now supersede the early injection systems that are mechanical. Single-point fuel injection (SPI) came after the carburetor system, followed by multipoint injection (MPI), and direct injections. The technological trend of the development of fuel-injection systems is shown in Figure 9.

The injector in a single-point injection system sprays fuel at atmospheric pressure, and as a result, the pressure regulator can constantly maintain gauge pressure. The single-point fuel-injection system (throttle-body fuel injection) is considered cheaper than multipoint fuel injection. It can result in a power reduction of $10 \%$ compared to a multipoint injection system [170]. CNG engines with single-point injection systems encounter lower IMEP, amounting to $13.8 \%$ at rated speeds compared to gasoline engines [183]. The fueling level of multipoint injection is controlled by the duration of injection pulses and fuel supply pressure, allowing for multipoint injection to gain higher power output compared to single-point injection (SPI) [184]. The fuel injector of the multipoint-injection systems senses the inlet manifold unlike the single-point-injection system, so as to maintain a constant differential pressure across the injection [179]. Moreover, the MPI system uses a more sophisticated system compared to SPI, one of which is the engine control unit (ECU) that monitors and controls the injection parameters, including injection timing, injection duration, and the amount of fuel required by 
each cylinder [9]. It was reported that CNG engines employing MPI systems resulted in 3 to $5 \%$ better performance than SPI CNG systems. However, CNG engines employing MPI had a 10.4\% lower IMEP than gasoline engines using MPI systems [36]. Multipoint fuel injection is not uncommon in today's vehicles. Multipoint injection suffers at high load, where uniform fuel distribution cannot be achieved. As a result, the direct-injection system (DI) is considered as the most recent sophisticated fuel-injection system [185]. A typical spark-ignition direct-injection (SIDI) engine consists of a high-pressure fuel pump, injector, and ECU, where the ECU controls the amount of fuel injection and injection parameters, such as injection pressure and injection time [186]. It was reported that DI CNGs had increased engine torque at all engine speeds compared to MPI CNGs, due to higher volumetric efficiency, enhanced in-cylinder flow motion, and improved combustion with faster flame propagation [187]. The direct injection of CNG offers advantages regarding power output, an extension of lean limit, and unburned hydrocarbon (UHC) emission levels; it also increases IMEP by between $9 \%$ and $15 \%$ of that generated by the manifold injection [188,189].

Direct fuel injection leads to much better control of charge stratification, while simultaneously allowing homogeneous stoichiometric or lean mixtures to be formed by injecting fuel early during the induction stroke. This flexibility of controlling the timing and quantity of fuel injection electronically has advantages of reducing exhaust emissions while maintaining high power output with much better fuel economy than conventional port-injected engines [190,191]. The advanced high-pressure fuel injection in the DI system helps the engine operate efficiently with short response times and with injection quantities appropriate for a broad range of engine sizes. While regulating injection parameters such as injection pressure, injection timing, and spray angle controlling the mixture preparation, it also helps reduce emission and increases the power output of the engine [192].

\section{Reduction Emissions, Increased fuel economy}

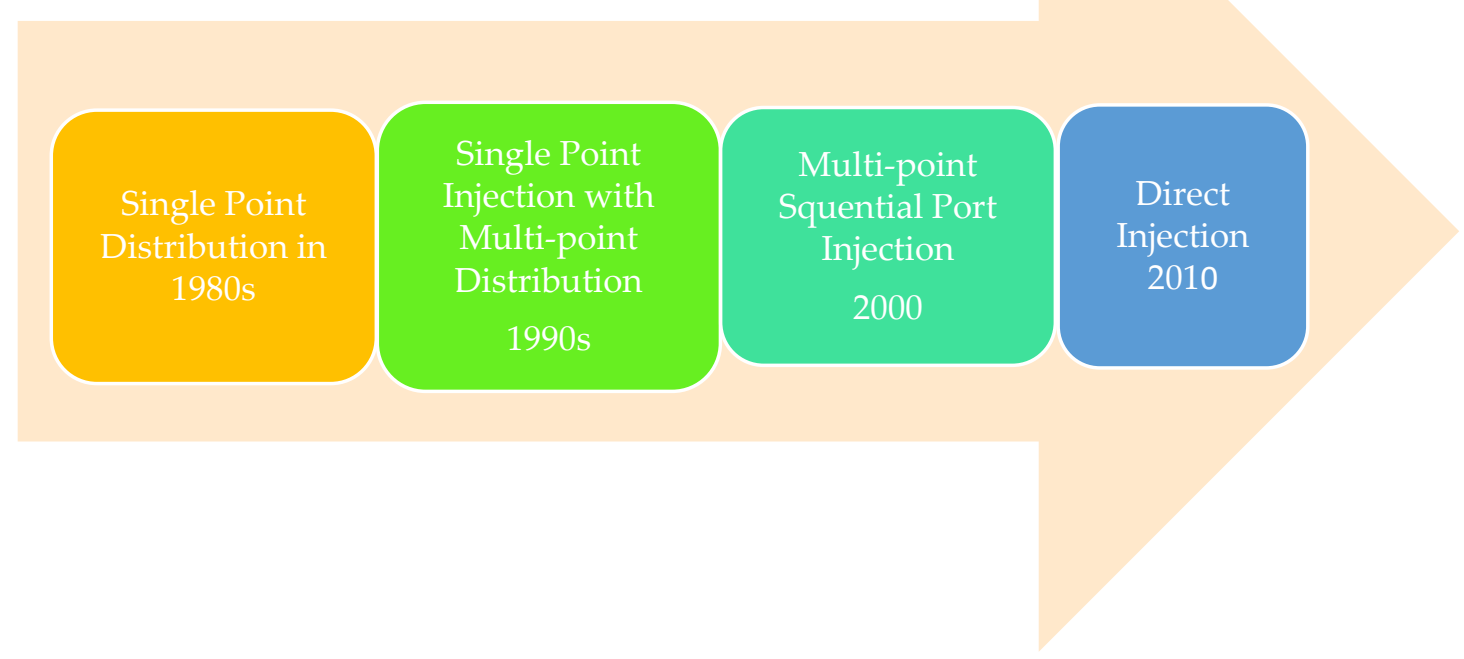

Figure 9. Technological development of fuel-injection systems [193].

The previous research and development of NGVs relied on retrofitting existing engine set-ups. Due to extensive studies on fueling technology and CNG in general, original equipment manufacture (OEM) engines are more reliable [194]. Direct-injection CNG engines are mostly designed based on the fuel properties of CNG, thereby eliminating performance loss associated with engine retrofitting [195]. However, CNG has a low flame speed $(38 \mathrm{~cm} / \mathrm{s})$ and narrow combustible range $(5.3-15 \%)$, and it requires a high ignition energy $(0.285 \mathrm{MJ})$, as shown in Table 7 . These factors lead to incomplete 
combustion, and thus, lower performance and higher CO and total hydrocarbon (THC) emissions [154]. Such outcomes are more exaggerated at lower speeds and low-load operation conditions [192]. There were different improvement strategies employed over the years to optimize the performance and emissions of CNG-fueled SIDI engines. Section 4.2 discusses the relevant strategies and their success rates.

\subsection{Performance and Emission Optimization Strategies of CNG Fuel in the Latest SI Engines}

Due to this fuel being abundant and having superior benefits to the environment, there are multiple efforts to optimize the engine-operating parameters, based on the limitations of the fuel properties. The parameters taken in to account for the optimization of the performance of DI CNG engines include compression ratio, fuel-injection timing and duration, lean combustion, fuel stratification, ignition timing and energy control, injection pressure, exhaust gas recirculation (EGR), boost pressure, optimization of intake and exhaust valve lift, and adding more flammable fuels (hydrogen and syngas).

\subsubsection{Effect of Compression Ratio}

Increasing the compression ratio of the engine affects the pressure and temperature of the cylinder before the fuel is injected and combustion begins. This further influences the thermal efficiency, and thus, the fuel economy and emissions. Different researchers studied the effect of compression ratio on the combustion, performance, and emissions of CNG fueling in direct-injection spark-ignition engines [196-199]. Damrongkijkosol and Kerdsuwan (2006) investigated the effects of compression ratio on the performance and emissions of CNG fuel in a four-cylinder four-stroke engine retrofitted from a diesel engine. The compression ratio varied from 9.0 to 10.5 with 0.5 intervals. The engine was operated in the range of 1000 to $4000 \mathrm{rpm}$. The CNG fuel performance and emissions at four different compression ratios were compared, and a further comparative evaluation was done with the base diesel fuel. Figure 10 shows the brake power of the retrofitted engine with CNG and diesel fueling. With an increase in compression ratio and engine speed, the brake power increased [199].

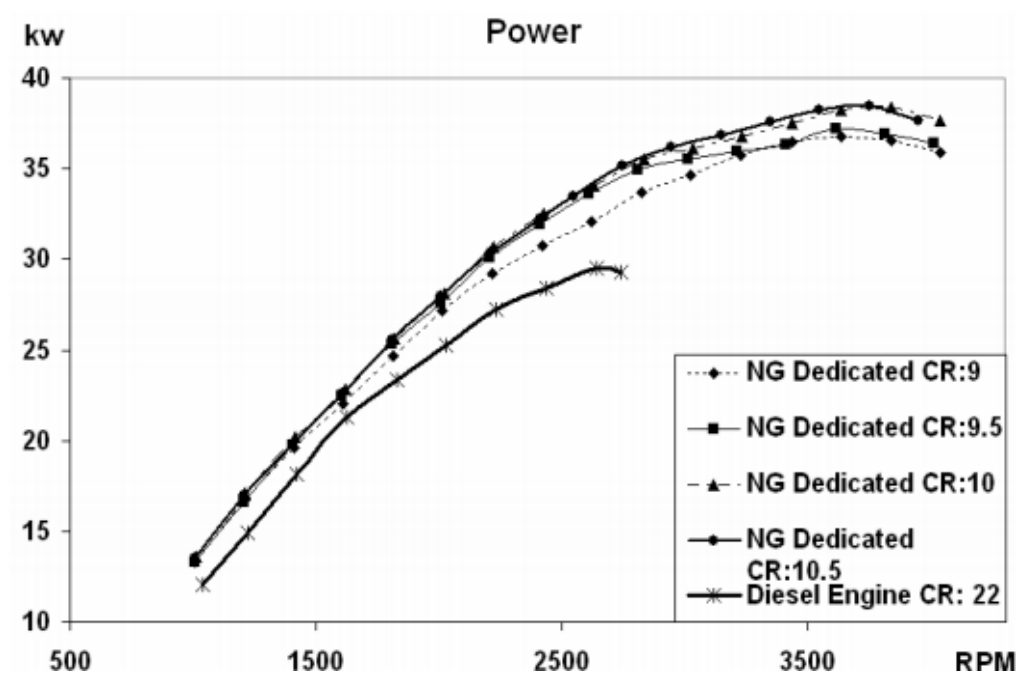

Figure 10. Brake power of CNG fuel at four different compression ratios and of diesel fuel [199].

Similarly, the effect of compression ratio on the combustion, performance, and emissions of a retrofitted single-cylinder engine (rated power was $4.5 \mathrm{~kW}$ at $1800 \mathrm{rpm}$ in petrol mode, and $3.5 \mathrm{~kW}$ at $1500 \mathrm{rpm}$ in diesel mode) fueled with CNG was investigated by Ramachandran and Waghmare [196]. The engine was operated at engine speeds ranging from 1200 to $1800 \mathrm{rpm}$. The compression ratio varied from 8:1 to 13:1 with an interval of 1 . It was reported that the engine did not experience 
knock over the range of compression ratios. Moreover, the peak pressure increased from $28.5 \mathrm{bar}$ at a compression ratio of 8:1 to 43 bar at a compression ratio of 13:1, as shown in Figure 11. In terms of performance and emission, a similar trend to the findings of Damrongkijkosol and Kerdsuwan [199] was reported [198]. Based on the autoignition temperature of CNG (813.15 K as shown in Table 7), the compression ratio often goes as high as $17-18$, based on the pressure-volume-temperature (P-V-T) polytrophic compression relationship ideal gas. However, the maximum compression ratio for CNG is bounded by the design of mechanical parts (mainly spark-electrode erosion) and the thermodynamic efficiency of the engine. Most researchers agree that the maximum working compression ratio in SI engines is $15[8,9]$.

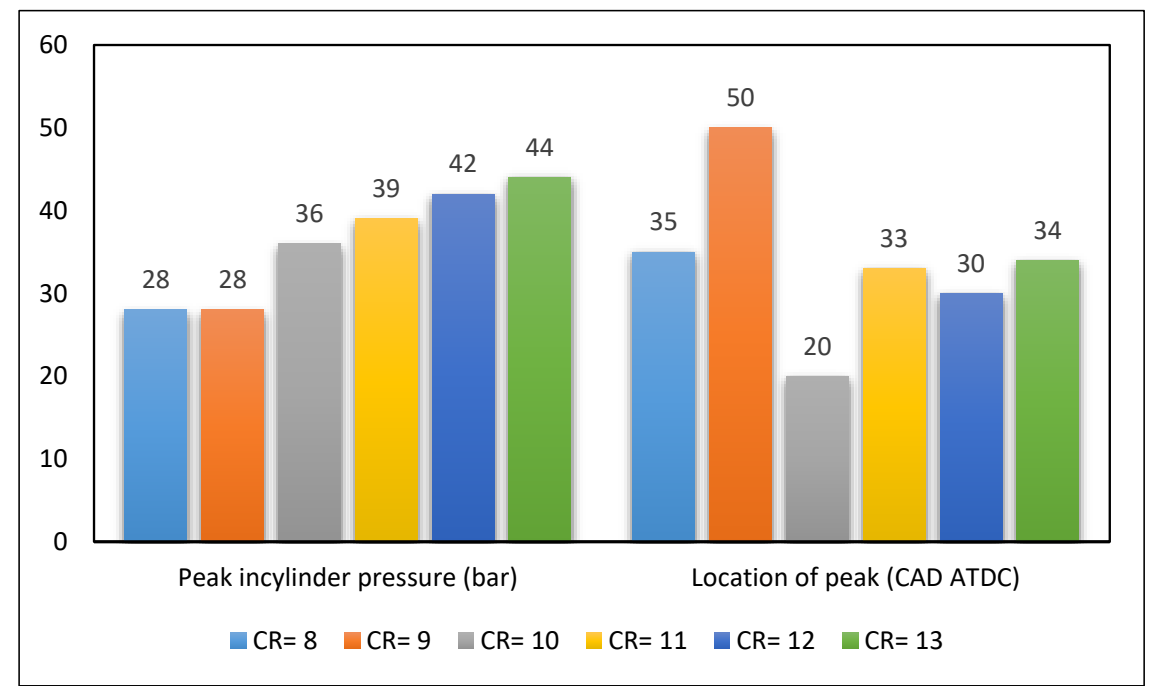

Figure 11. Peak in-cylinder pressure and its respective location of CNG under various compression ratios, modified from Reference [198].

\subsubsection{Effect of Lean Charge Strategy}

Another trend from diesel-engine operation in the CNG SIDI engines is the lean operation strategy. In the search for reduced greenhouse gas emissions and overall fuel consumption, the lean combustion strategy is an option explored in the research domain [192,200-202]. Lean combustion strategy works under both homogeneous and stratified charge depending on the extent of leanness. When the overall air-fuel ratio is maintained extremely lean, near to the lower flammability limit, the probability of an ignited mixture having a sustained flame is small [203]. In such cases, the strategy is mainly modified to have a fuel-stratification mechanism, so that a variable air-fuel ratio occurs around the combustion chamber. The stratification provides a relatively rich mixture near the igniter and a uniformly mixed ultra-lean mixture throughout the cylinder. Hagos et al. [192] reported an extension of the lean limit of CNG fuel with the use of a stratification fueling strategy. An extension of the lean limit of up to $10 \%$ was also reported by Evans et al. [204], as shown in Figure 12 for a partially stratified charge engine with a speed of $2000 \mathrm{rpm}$. Furthermore, the lean-burn strategy has superior performance with regards to emissions, NOx in particular [200]. The challenges with lean charge involve engine stability, as a result of reduced burning rate $[9,200,202]$, and suitability only for part-load conditions and low-MEP operation [8]. Even though gaseous fuels are known for their lower emission of THC, lean-burn CNG has relatively higher emissions of THC, resulting from the unburned mixture in the end zone [205]. The effect of the air-fuel ratio on the combustion efficiency and emissions is shown in Figure 13. According to the review by Cho and $\mathrm{He}$ [9], the combustion instability under the lean-burn strategy can be further improved by optimizing certain parameters. These are the in-cylinder air motion, ignition energy, quality of natural gas, moisture content of induced air, residual fraction, and mixture temperature during ignition, which is a function of the compression ratio. 


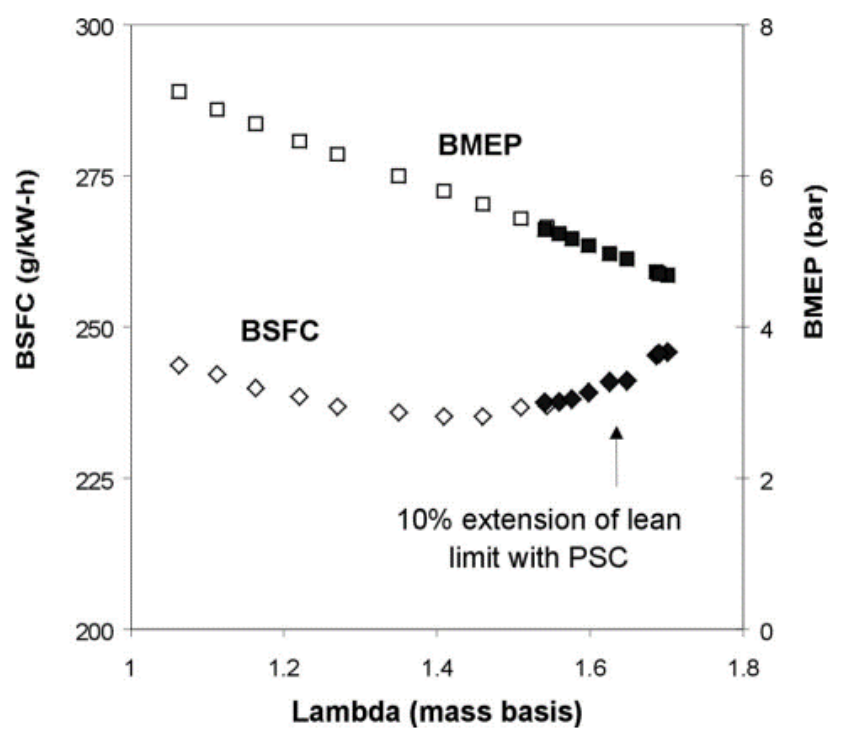

Figure 12. Extension of lean limit by partially stratified charge at 2000 rpm [204].

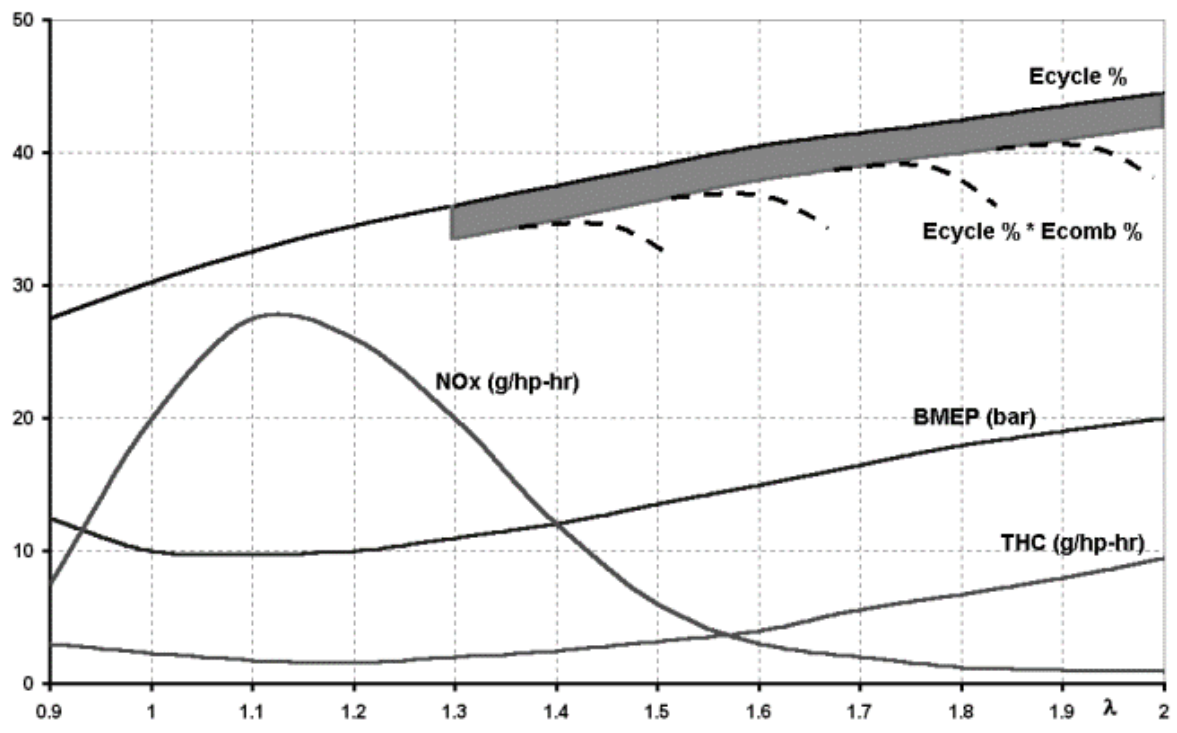

Figure 13. Effect of air-fuel ratio of natural gas [205].

\subsubsection{Effect of Injection Timing and Injection Pressure}

There are various efforts reported in the literature to improve the performance of CNG SIDI engines by injecting the fuel late after the inlet valve closes (IVC), thereby improving the volumetric efficiency drop [162,206-210]. When fuel is injected after the inlet valve closes (IVC), the air-breathing capacity of the engine does not get influenced by the type of fuel. However, there is insufficient time for the fuel to completely mix with the air when the fuel is injected late, leading to a slow combustion rate. For fast-burning fuels such as hydrogen and syngas, this fuel-injection strategy is adopted and it currently attracts attention $[159,211,212]$. Aziz et al. (2010) used a dedicated CNG engine for the study of the effect of injection timing on the combustion, performance, and emissions of SIDI engines. The engine test-bed was a single-cylinder research engine (SCRE) with a compression ratio of 14 . The test was conducted at full-load conditions with the ignition point set at maximum brake torque (MBT) for speeds of 2000-5000 rpm. A high-pressure injector (18 bar) was used in a central injection system. The air-fuel ratio was set at the stoichiometric condition of 17.4 for CNG gas. Furthermore, 
$300^{\circ}$ before top dead center (BTDC) injection timing was used as a baseline to simulate port-injection systems as a comparison for other direct-injection systems. By applying $300^{\circ} \mathrm{BTDC}$ injection timing, fuel was injected during intake stroke, which is assumed to have the same mixture properties as port injection systems. On the other hand, $180^{\circ}$ BTDC was used to simulate direct injection and $120^{\circ}$ BTDC was used to simulate late injection after the IVC. Figure 14 shows the injection-duration mapping for the three injections, with reference to the valve inlet valve opening and closing, and the start of ignition. They reported that direct injection performed better across most operation conditions, while port injection and late injection performed better at higher and lower speeds, respectively. Figures 15 and 16 show the performance and combustion trends of different injection timings, respectively [162].

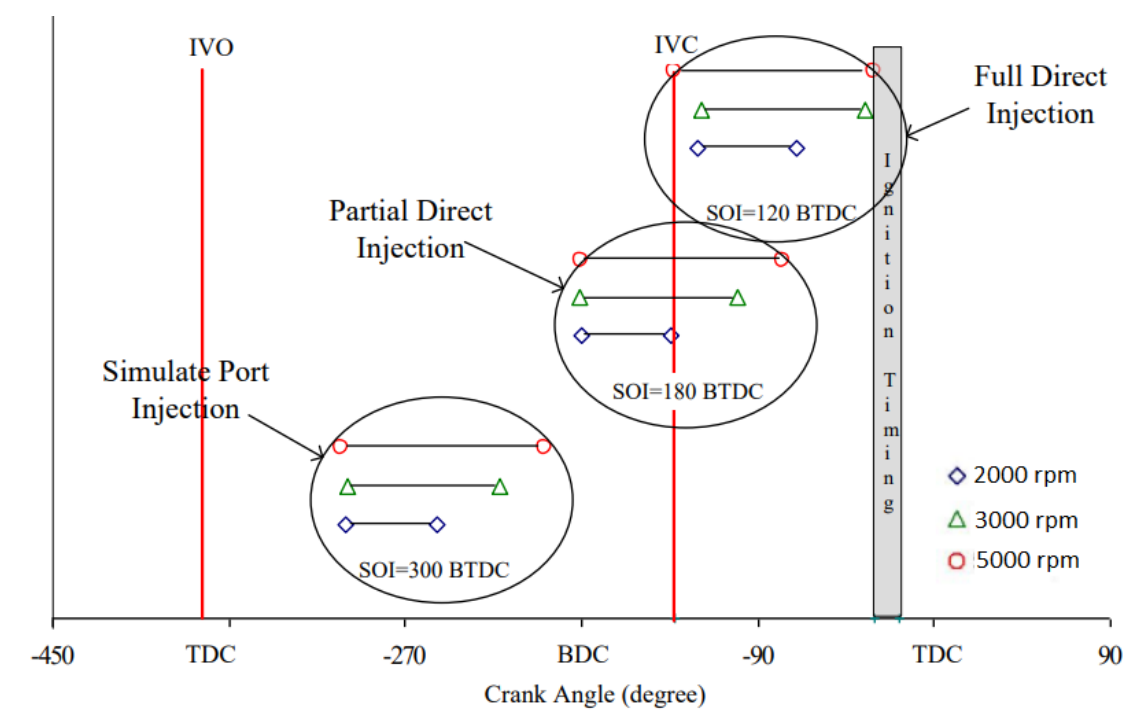

Figure 14. Injection duration for different injection timings for engine speeds $2000 \mathrm{rpm}, 3000 \mathrm{rpm}$, and $5000 \mathrm{rpm}$ [162].

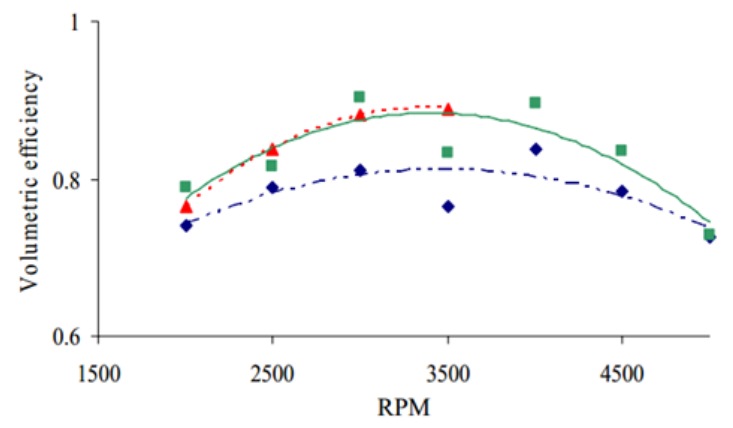

(a)

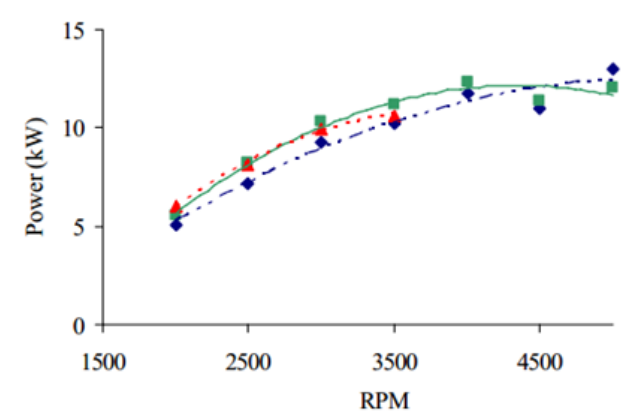

(b)

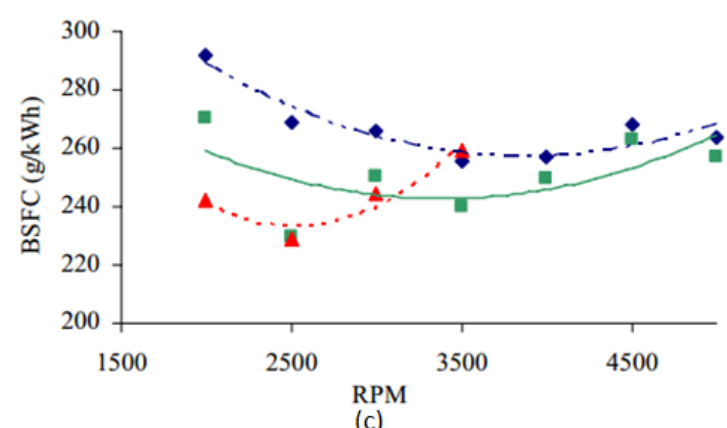

$\bullet 300=180 \wedge 120$

(c)

Figure 15. Volumetric efficiency (a), brake power (b), and brake-specific fuel consumption (BSFC) (c) of different injection timings at various engine speeds [162]. 
A similar study was conducted by Aljamali et al. [206] on a four-stroke four-cylinder direct-injection spark-ignition engine by varying the injection timings on $120^{\circ} \mathrm{BTDC}, 180^{\circ} \mathrm{BTDC}, 300^{\circ}$ $\mathrm{BTDC}$, and $360^{\circ} \mathrm{BTDC}$. The speed was varied from $1500 \mathrm{rpm}$ to $4000 \mathrm{rpm}$ with an interval of $500 \mathrm{rpm}$. Maximum performance was found with the $120^{\circ}$ BTDC at most engine speeds tested. At $4000 \mathrm{rpm}$, $180^{\circ}$ BTDC was reported to perform better than the other injection timings. Better volumetric efficiency and higher performance were reported when fuel was injected near the IVC [210].

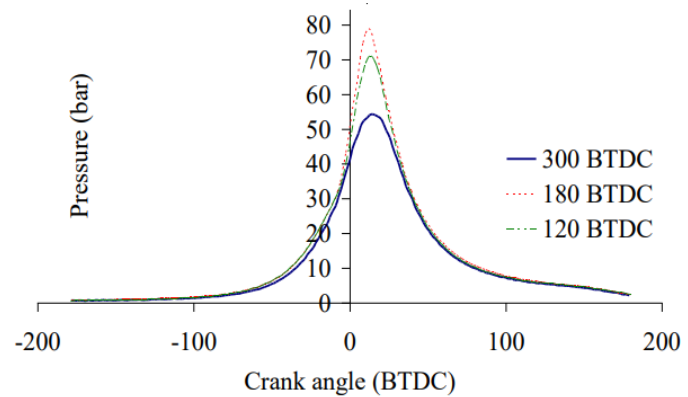

(a)

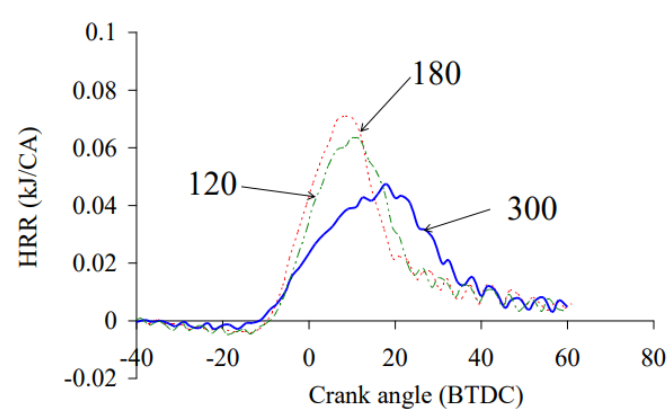

(b)

Figure 16. In-cylinder pressure (a), heat release rate (b), and mass fraction burned (c) for different injection timings at an engine speed of $3000 \mathrm{rpm}$ [213].

Zeng et al. [208] investigated the effect of injection timing on the combustion characteristics of CNG fueling in an SIDI engine. The compression ratio of the engine under study was $8: 1$, and the throttle was kept at $70 \%$ open. The engine was operated at $1200 \mathrm{rpm}$, and the ignition advance was kept at $32^{\circ}$ BTDC. Unlike the two studies discussed earlier, the injection duration was held constant, and the start of injection was varied from 150 to $210^{\circ}$ BTDC with a $10^{\circ}$ crank angle (CA). The maximum pressure, a higher heat release rate, and the shortest heat release duration were observed with $180^{\circ}$ BTDC, similar to the observations of Aziz et al. [164] and Aljamali et al. [206]. They reported that injection timing had considerable influence over the combustion characteristics, for late injection in particular. Late injection affects the air-and-fuel mixing, as there is insufficient time before the onset of ignition. A similar observation was also reported elsewhere by Aziz et al. [162] and Aljamali et al. [206]. Late injection was also reported to be associated with higher emissions of HC and CO.

Firmansyah (2007) investigated the effect of fuel-injection pressure on the combustion, performance, and emissions of a CNG SIDI engine with a compression ratio of 14 . The engine was operated at wide-open throttle, and the speed was varied from 2000 to $5000 \mathrm{rpm}$. The injection pressures considered in the study were $7.5 \mathrm{kPa}, 12 \mathrm{kPa}$, and $18 \mathrm{kPa}$. It was shown that an injection pressure of $18 \mathrm{kPa}$ had better performance at speeds below $3500 \mathrm{rpm}$, while $12 \mathrm{kPa}$ showed superior performance at engine speeds higher than $3500 \mathrm{rpm}$. For the combustion process, IMEP values at $18 \mathrm{kPa}$ were found to be the highest for all engine speeds, despite showing a slower burning rate compared to that at $12 \mathrm{kPa}$. Furthermore, $18 \mathrm{kPa}$ showed greatest variation at lower speeds, decreasing as engine speed increased [213]. However, an insignificant effect was reported on the combustion characteristics by a change in injection pressure by Song et al. (2017). The experiment was conducted using various injection pressures of $5 \mathrm{kPa}, 8 \mathrm{kPa}$, and $11 \mathrm{kPa}$ [210]. 


\subsubsection{Effect of Ignition Timing and Ignition Energy Control}

In addition to the optimization of injection timing and injection pressure, there are various research studies on the optimization of ignition timing and ignition energy control. Ignition advances for maximum brake torque (MBT) affect the properties of the fuel, the equivalence ratio, and the burned-gas mixture. The engine design and operating conditions also have a significant impact on the optimal conditions. As shown in Figure 7, combustion in SI engines starts slightly before the compression of TDC and continues until slightly after TDC, ending after the point of peak pressure [155]. All stages of combustion (flame development, flame propagation, and the secure termination), as well as the length of the flame travel path across the chamber, influence ignition advances for MBT. There is a lack of consistency on ignition advances for MBT of CNG in the literature. Bell et al. (1993), as cited by Ehsan (2006), reported it as 15-20 CA more than that of gasoline [214,215]. This value was contradicted by $\mathrm{Cho}$ and $\mathrm{He}$ (2007), placing it at 2-10 CA more than that of gasoline [9]. This is mainly due to the lower laminar flame speed of CNG compared to gasoline $(38 \mathrm{~cm} / \mathrm{s}$ for CNG compared to $49 \mathrm{~cm} / \mathrm{s}$ for gasoline, as shown in Table 7). Maximum brake torque is attained by igniting the fuel-air mixture so as to attain peak pressure at slightly after TDC, thereby maximizing the transfer of expansion work from the combustion gas to the piston, while reducing the transfer of compression work from the piston to the gas [155]. Figure 17 shows the effect of ignition advances on the conversion efficiency of CNG fuel, as observed by Dimopoulos et al. [216]. The optimal ignition advance for maximum fuel-conversion efficiency of CNG was reported to be from $28-32^{\circ}$ BTDC. This result was similar to results obtained by Bell et al. [215]. In a separate study, Khan et al. (2014) investigated the effect of ignition timing on CNG at two different injection timings ( $60^{\circ} \mathrm{BTDC}$ and $\left.90^{\circ} \mathrm{BTDC}\right)$. The 8.5:1 compression ratio two-cylinder four-stroke engine was run at $3000 \mathrm{rpm}$, and the ignition timings evaluated were $50,44,34,24,22$, and $20^{\circ}$ BTDC. The performance and emissions of the engine were studied. Ignition advances for MBT was reported at $40^{\circ}$ BTDC and $34^{\circ}$ BTDC for injection timings of $60^{\circ}$ BTDC and $90^{\circ}$ BTDC, respectively. The work did not specify the air-fuel ratio of the charge used in the study [217]. Similarly, ignition advances for MBT increase with a decrease in fuel-air ratio $(\varphi)$ from the stoichiometric fuel-air ratio $(\varphi=1)$ [9]. This is due to the decrease in laminar flame speed with an increase in the air-fuel ratio [218]. Figure 18 shows the variation in laminar flame speed of $\mathrm{CH}_{4}$ and NG under atmospheric conditions. The maximum laminar flame speed for NG (around $38 \mathrm{~cm} / \mathrm{s}$, as also stated in Table 7) was obtained at $\varphi=1.1$. The amount of energy and the rate of energy release decreased with an increase in fuel-air mixture leanness. As a result, the laminar flame speed decreased. With a lower laminar flame speed, the mixture required a longer duration to reach peak pressure. If ignition timing is not well advanced, the position of peak pressure gets pushed far away from TDC, leading to a decrease in the transfer of expansion work from the combustion gas [155].

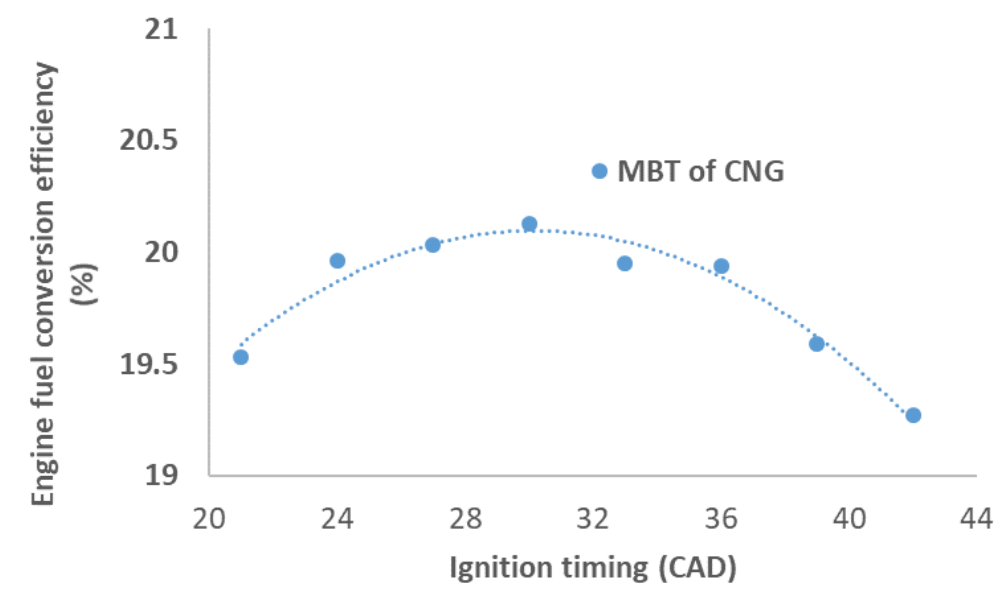

Figure 17. Ignition advance for maximum brake torque (MBT) extracted from Reference [216]. 


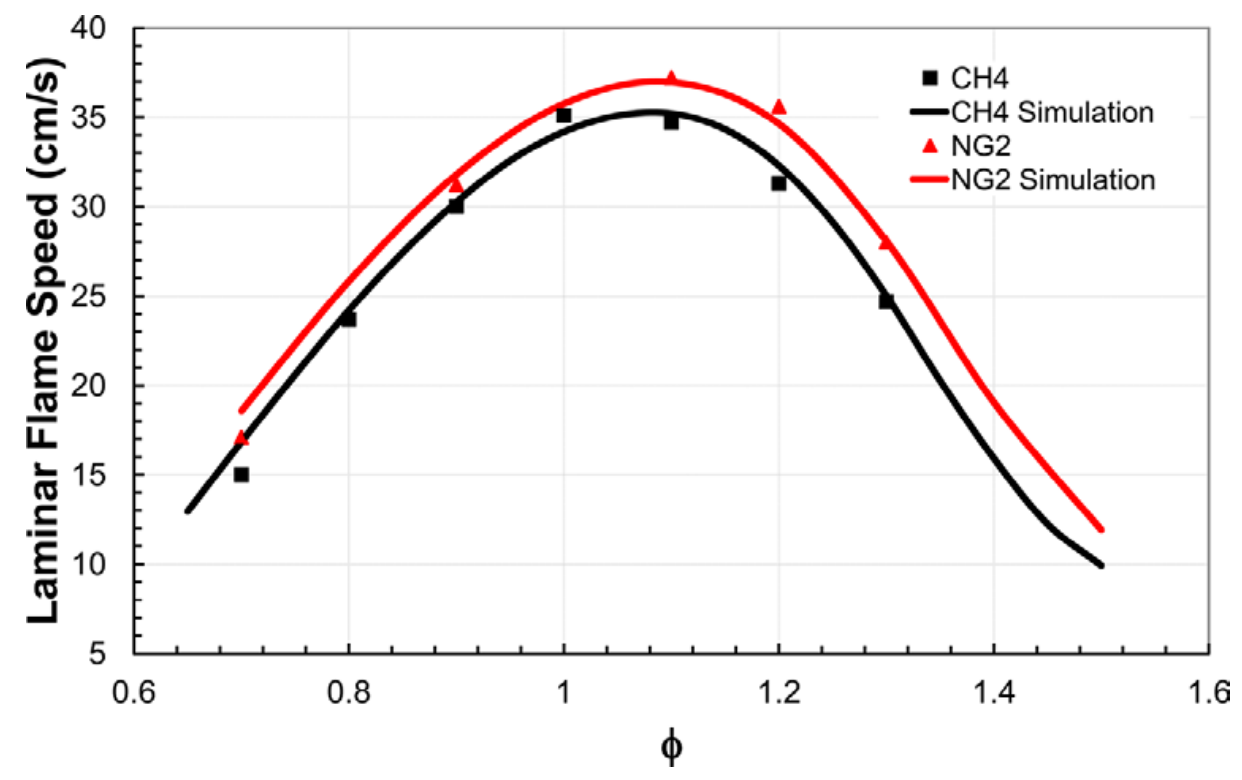

Figure 18. Laminar flame speed $(\mathrm{cm} / \mathrm{s})$ versus equivalence ratio $(\varphi)$ for $\mathrm{CH}_{4}$ and $\mathrm{NG}$ under atmospheric conditions [218].

\subsubsection{Effect of Boost Pressure}

The volumetric efficiency loss due to the displacement of air by gaseous fuels can be compensated by boosting the induced air, thereby increasing the breathing efficiency of the engine [219]. The volumetric efficiency of gaseous-fuel engines is also affected by the lack of evaporative cooling that is associated with liquid fuels $[220,221]$. In terms of the fuel properties, CNG has a lower laminar flame speed and a lower energy density compared to its liquid counterpart, as shown in Table 7 . By doing so, the fuel economy of the engine, and thus, the pollutant emissions from the engine can be reduced. According to Hillstrom [222], CNG is the best candidate for such an optimization due to its higher octane number. There are a number of studies on the effect of boost pressure on the performance and emissions of CNG fuel in spark-ignition engines [92,169,222,223]. As cited in Cho and He [9], due to a high boost pressure is needed to overcome the performance loss of CNG fueling in SIDI engines, this forces the spark plug to work under more stress, leading to frequent failure [224]. As a result, Chala et al. [92] recommended the use of lower boost pressure, in the range of $7.5 \mathrm{kPa}$, combined with optimal fuel-injection timing for better performance and emissions, as shown in Figure 19.

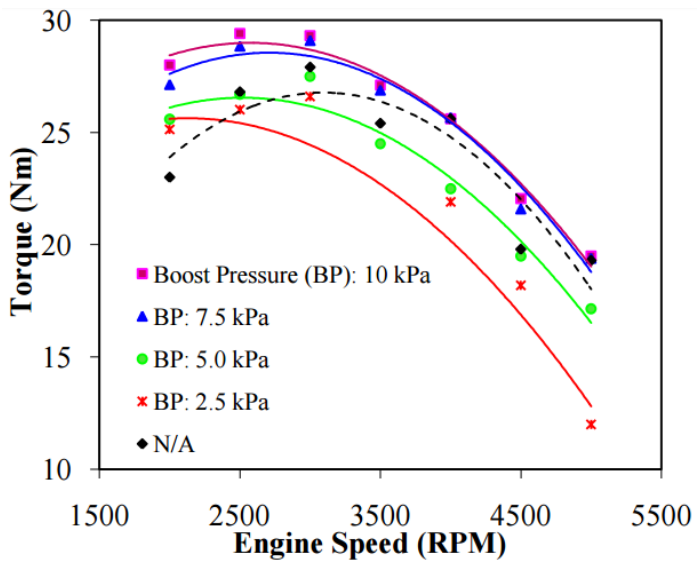

(a)

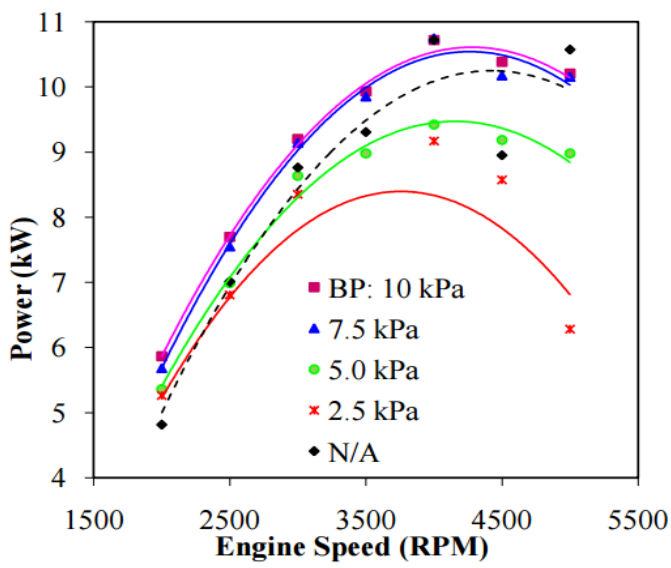

(b)

Figure 19. Cont. 


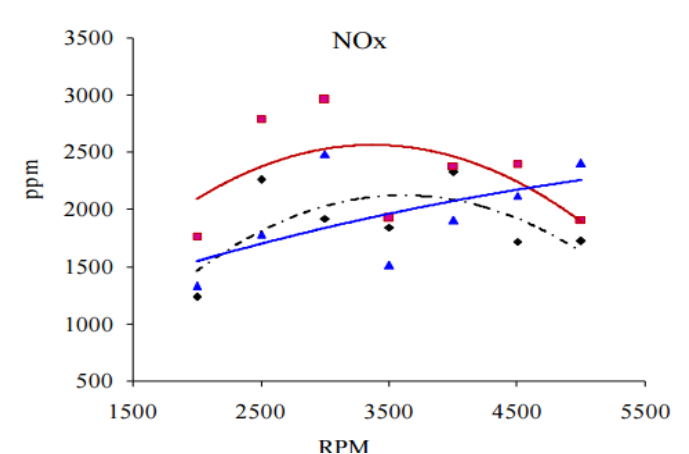

(c)

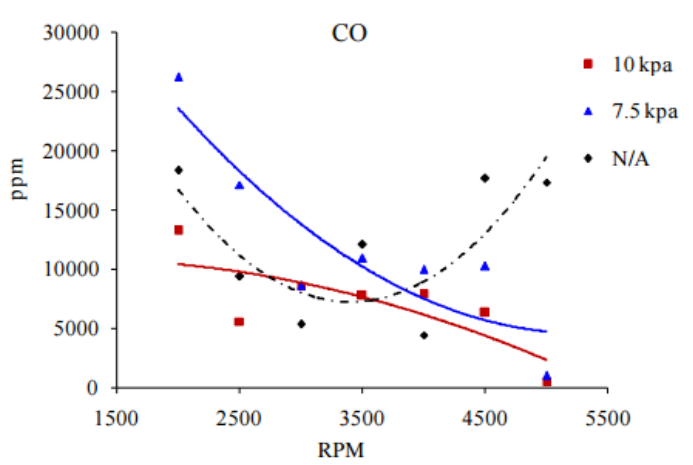

(d)

Figure 19. Performance (brake torque (a) and brake power (b)) and emissions (nitrogen oxides (NOx) (c) and $\mathrm{CO}(\mathbf{d})$ ) of a CNG spark-ignition direct-injection (SIDI) engine at lower boost pressure [92].

\subsubsection{Effect of EGR}

The use of exhaust gas recirculation (EGR) was also on the cards for CNG-fueled SI engines. EGR in lean-burn CNG-fueled SI engines is not suitable, as it severely affects the stability of combustion. This is caused by dilution of the fuel-air mixture with EGR creating trouble for the early flame to sustain and develop. In a stoichiometric air-fuel ratio, however, there are numerous studies on the effect of EGR on the combustion, performance, and emissions, both experimental and numerical [225-228]. Ibrahim and co-authors employed EGR with low and high boost pressure at 13 (intake pressure of $113 \mathrm{kPa}$ ), 100 (intake pressure of $200 \mathrm{kPa}$ ), and $150 \mathrm{kPa}$ (intake pressure of $250 \mathrm{kPa}$ ). The EGR was cooled down before it was diluted with the mixture. They reported a decrease in NOx emissions, an increase in engine performance, and improved fuel economy [225,226]. Sen et al. [227] investigated the effect of EGR on the combustion cycle-to-cycle variation of CNG fueling at a stoichiometric ratio by varying the EGR from $0-20 \%$ in 5\% intervals. The engine was operated at $2000 \mathrm{rpm}$. The result indicated an increase in the cyclic variation of IMEP with an increase in the percentage of EGR.

\subsubsection{Effect of Valve Lift and Valve Timing}

Among the engine hardware-based studies, intake and exhaust valve-lift optimization is believed to enhance the combustion characteristics, engine performance, and emissions of CNG-fueled engines. Optimization of the intake and exhaust valve lift contributes to the extent of turbulence on the engine mainly during the early flame-development stage, leading to a sustained flame and stable combustion $[203,229]$. Soid et al. [230] numerically investigated the effect of different valve timings on the performance of a methane-fueled small engine. This was done by varying the inlet and exhaust valve openings. A $5-10 \%$ improvement in performance was reported by retarding the exhaust valve opening by $10^{\circ} \mathrm{CA}$. The effect of dissimilar valve timings on the turbulence in the combustion chamber and its impact on the flame propagation stage were investigated by Ramasamy et al. [229]. An improvement in the combustion characteristics (peak pressure) and flame propagation were reported with the use of dissimilar valve timings.

\subsubsection{Effect of Fuel Blending}

Fuel blending is common in liquid fuels for both SI and CI engines. This is mainly done for fossil-fuel substitution and oxygenation. In gaseous fuels, with CNG in particular, the lower laminar-flame-speed characteristics attracted researchers to add higher laminar-flame-speed fuels, such as hydrogen and syngas [218,231-235]. Figure 20 shows the effect of hydrogen blending in natural gas over a range of equivalence ratios. The addition of a small quantity of hydrogen was found to have less effect on the laminar flame speed. However, Mohammed et al. [233] reported a significant influence on the performance, emissions, and combustion of a CNG DI engine upon blending a 
small quantity of hydrogen, as shown in Figure 21. There are different success rates reported in the literature with hydrogen blending. Almost all research findings have a consensus that, technically, the enriching of natural gas with higher laminar-flame-speed fuels improves the combustion and performance of the engine [236]. However, this fuel-based improvement has operational limitations. Hydrogen and hydrogen-rich syngas have storage-related concerns. They are associated with hydrogen embrittlement. On the other hand, accompaniment with another high-pressure storage tank for the high laminar-flame-speed fuels would lead to space limitations and high inertia.

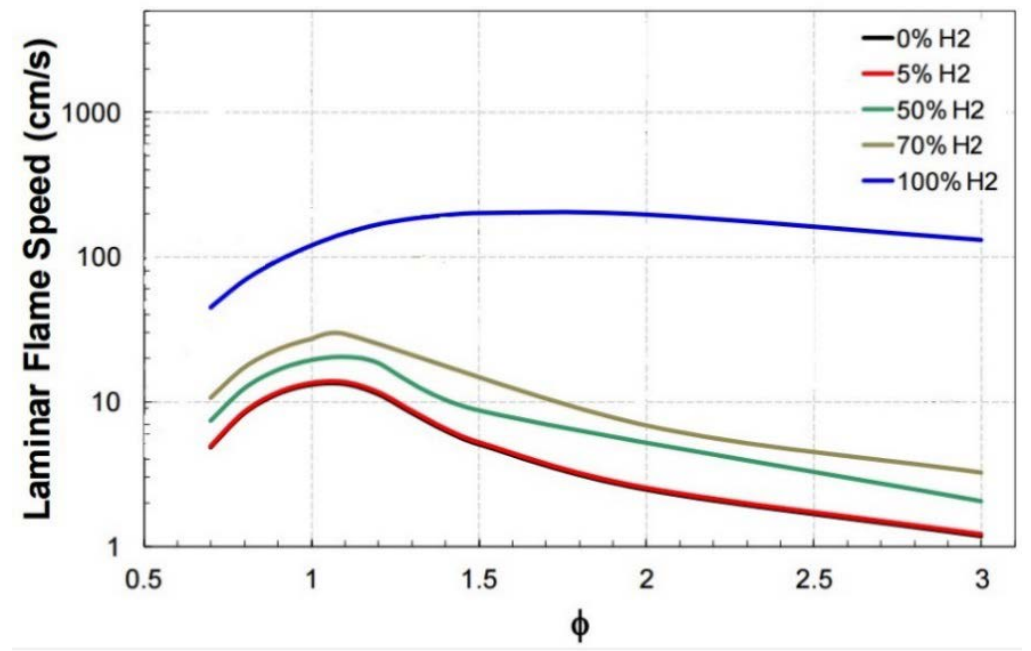

Figure 20. Effect of blending hydrogen in natural gas on the laminar flame speed at $15 \mathrm{kPa}$ and $300 \mathrm{~K}$, extracted from Reference [218].

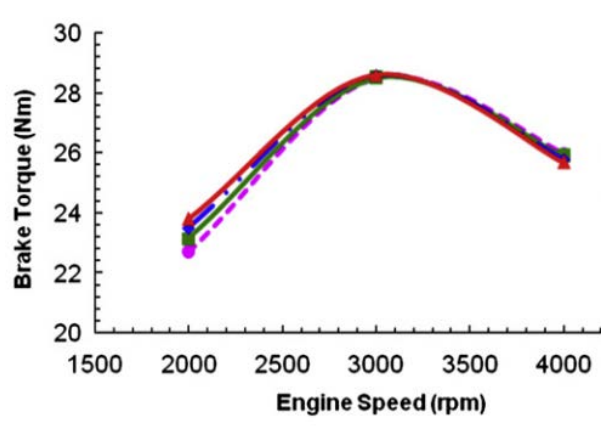

(a)

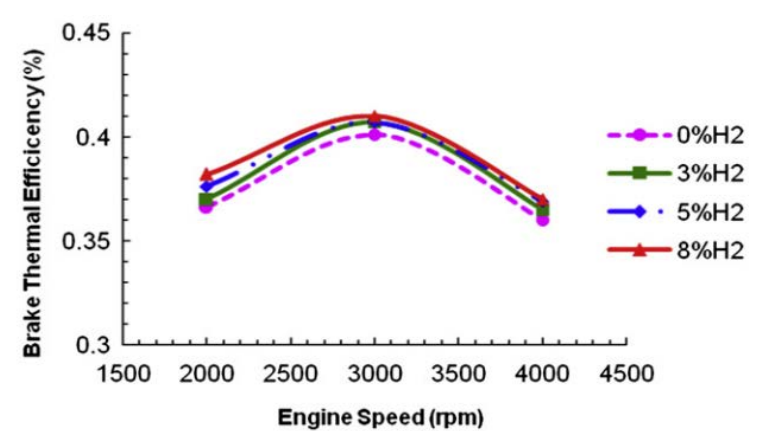

(b)

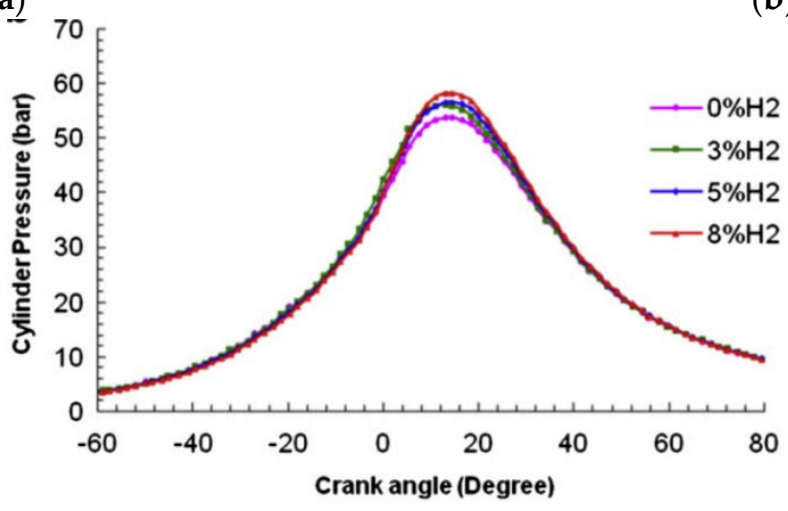

(c)

Figure 21. Cont. 


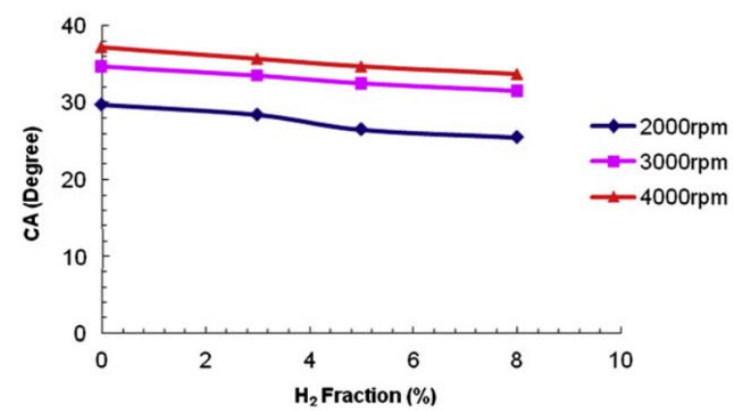

(d)

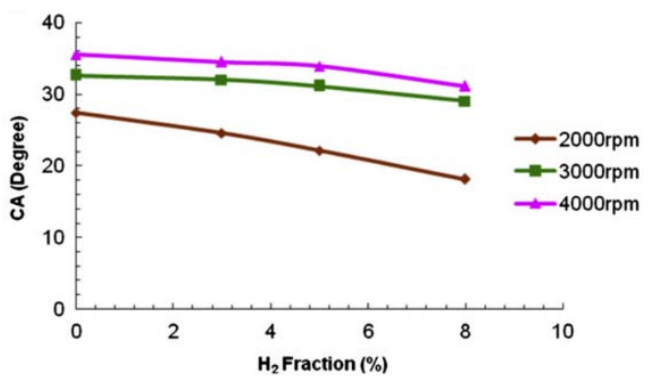

(e)

Figure 21. Effect of adding a small fraction of hydrogen on the performance and combustion of a CNG SI engine. (a) Brake torque versus engine speed; (b) brake thermal efficiency (BTE) versus engine speed; (c) in-cylinder pressure versus crank angle for various hydrogen-blending ratios; (d) flame-development duration versus $\mathrm{H}_{2}$ percentage; (e) rapid-combustion duration versus $\mathrm{H}_{2}$ percentage [233].

\subsection{CNG in CI Engines}

The various strategies employed in the performance improvement of SIDI engines are mostly effective at low loads. However, with stringent emission regulations in high-torque diesel engines, significant interest is arising in dedicated CNG engines for heavy-duty transport applications. It is impossible to achieve ignition in compression-ignition engines due to the fact that CNG has a higher autoignition temperature. Therefore, $\mathrm{CNG}$ should be blended with a low-autoignition-temperature fuel such as diesel so as to achieve ignition in CI engines. Such arrangements can be done by either a mixed-fuel or dual-fuel arrangement. The US Environmental Protection Agency designates these two arrangements as similar. Technically, a small quantity of diesel is added in a mixed-fuel arrangement, which is sufficient only for the initiation of ignition, while up to $90 \%$ of the fuel induced is CNG. The Cummins Westport ISX12 is the latest engine running with a mixed-fuel-mode CNG engine. This engine is the latest CNG engine suitable for heavy-duty applications [237]. The engine is designed to run on CNG, liquid petroleum gas (LPG), and biomethane, and it is equipped with a maintenance-free three-way catalyst after the treatment of gas. The engine is designed to work under stoichiometric conditions with cooled-EGR technology, thereby combining the benefits of a stoichiometric ratio and lean-burn combustion [237]. In a dual-fuel arrangement, however, CNG is used for diesel substitution while the engine is still able to run using 100\% diesel mode. The main motivation in using CNG and other gaseous fuels in a diesel engine is for the possible substitution of diesel by a gaseous fuel, thereby reducing cost, minimizing pollutant emissions such as NOx and particulate matter, and further increasing the performance of the engine. One of the engine technologies in dual-fuel mode, approved by the US Environmental Protection Agency in 2013, is the Detroit Diesel S60 12.7-L engine. It was claimed that up to 60\% diesel replacement, noise and PM reduction by $40 \%$, and smoke reduction by $50 \%$ are some of the benefits [238]. However, Wagemakers and Leermakers [239] reviewed the effect of the dual fueling of diesel and various gaseous fuels on performance and emission. CNG, LPG, syngas, and hydrogen are some of the gaseous fuels considered in their review. They reported that all gaseous fuels, when applied to diesel-fuel combustion as a dual fuel, could decrease soot emissions except for syngas. A reduction in NOx emissions was reported when both CNG and LPG were used as primary fuels. However, syngas and hydrogen increased NOx levels compared to diesel combustion. Unburned hydrocarbons and CO demonstrated an increased trend with all gaseous fuels. With regards to the effect of these fuels on efficiency, hydrogen and LPG had a positive effect, while syngas and CNG had a negative effect. 


\section{Conclusions and Perspectives}

In the current review work, recent works focusing on natural-gas utilization in IC engines, particularly spark-ignition engines, were discussed. Progress on the development of engine technology, as well as influencing engine parameters and their impact on engine performance and emissions, and the socio-economic prospect of the fuel were evaluated. Recently, in the automotive industry, the application of CNG in SI engines is more customary than before. The driving force for such movement is due to the technical superiority of the fuel as compared to its conventional counterparts. Technological advantages under spotlight are the higher octane number, higher autoignition temperature, high hydrogen-to-carbon ratio, gaseous phase under atmospheric conditions, and wider flammability limit. The higher octane number of natural gas allows for high compression of the engine, which in turn, results in enhanced power and higher total combustion efficiency. CNG/LNG vehicles reduce GHG emissions by $10-20 \%$ compared to gasoline vehicles. The lower number of particulates from CNG also results in reduced wear of the parts in relative motion compared to liquid fuels, and this, in turn, reduces the maintenance of $\mathrm{CNG}$ engines, despite the higher compression ratio and higher combustion temperature potentially slightly raising stress in the moving parts. The lower frictional loss in CNG vehicles could also result in reduced noise. Moreover, natural gas has lower fuel consumption, which is considered as economical for use as a fuel. In addition to the technical advantages, natural gas is abundantly available. The recent expansion in the production of natural gas from shale (shale gas) further increased the relevance of the fuel in the transportation sector. Globally, the production potential and capacity advanced in recent years. As a result, the natural-gas resource potential map is regularly being revised, even though such trends are marred by geopolitical complexities. On the other hand, conventional fuels are having trouble complying with the ever-increasing emission restrictions. This situation provides an upper hand to natural gas in tackling the GHG emission concerns.

The research and development of natural-gas-fueled IC engines focused on modified gasoline engines. Consequently, the perception of the fuel with researchers and end users was slightly negative, despite it having enormous economic, technical, and environmental benefits. The use of natural gas can result in a significant reduction in maximum power, torque, and volumetric efficiency at fully open throttle operation, which is attributed to the displacement of air by natural gas and the absence of evaporation cooling. Natural-gas engines have a lower power output than gasoline-fueled engines, mainly due to the lower energy content of natural gas, the displacement of air, and longer combustion durations. CNG vehicles have a 10-20\% reduction in power compared to their gasoline counterparts after modification/retrofit. Comparatively, the natural-gas engine conversion from gasoline-fueled engines requires some modifications on the ignition system and valve trains, as well as the storage and fueling systems. Our transportation system was $100 \%$ reliant on conventional fuels. As a result, our technological development and infrastructure are tailored to that mode. In designing alternative or replacement fuels, the existing technological set-up and infrastructure should be taken into account. There are close to 1.2 billion cars in operation. In addition to designing a new engine based on its fuel characteristics, the adaptation and retrofitting of existing engines to accommodate CNG in either a standalone mode or as a dual fuel is on the rise.

Low engine efficiency and power output are issues encountered with retrofitted natural-gas engines. It was reported that natural gas results in a $10 \%$ lower power output compared to equivalent gasoline-fueled vehicles. In regular service, natural-gas engines consume 25-35\% more energy than their diesel counterparts. Pumping loss and lower volumetric efficiency could arise due to the gaseous nature of natural gas. More unburned fuel could also result as CNG burns slower than conventional liquid fuels. Moreover, the cooling effect produced due to the vaporization of liquid fuel is absent when using CNG. The higher temperature due to the higher compression ratio of CNG engines usually results in higher NOx emissions. A sluggish start-up is another disadvantage of natural-gas engines, although this effect could be minimized by adding hydrogen as a secondary fuel.

Since the development of tailored direct-injection CNG engines, optimal engine-operating conditions were specified, and the performance and emissions of CNG DI engines became on par 
with their gasoline counterpart. Due to CNG being a gaseous fuel, fuel-and-air mixing is not an issue. As a result, injection timing can be varied with the appropriate design of an injector. An injector with a narrow-angle design was found to be suitable for natural-gas fuel by different researchers.

There are different mechanisms deployed in order to overcome the efficiency deficit when using natural gas, such as working toward lean-burn combustion, supercharging, optimizing fuel-injection parameters (injection timing, injection pressure, and injection duration), optimizing ignition energy, ignition timing, and the optimization of valve timing. All these strategies have their strengths and weaknesses, as discussed in Section 4.2 in detail. Lean-burn technology would increase engine efficiency, and hence, the vehicle capacity range. Moreover, electronics like variable valve timing, skip-fire, and new engine technologies can help enhance the performance of gas engines. However, these enhancements are at the cost of engine torque. As a result, they are only suitable for small-load and low-speed operations. Similarly, improvements resulting from late injection of the fuel were associated with increased emissions of $\mathrm{CO}$ and HC. The combined effect of the engine-based mechanisms mentioned above could slightly improve SI engine efficiency. However, this improvement cannot beat the expectation of energy security and GHG emission concerns. As a result, fuel-based improvements, such as mixing CNG with high laminar-speed fuels and coupling engines with steam reformers for inline syngas mixing (research in its early stage), are on the table. A radical line of thinking currently in the research-and-development stage is the use of CNG in high-pressure DI diesel engines. This is achieved through mixed- and dual-fueling modes, where both CNG and diesel are injected into the cylinder at various times. The pilot fuel (diesel) is injected to initiate the ignition. In this arrangement, a maximum diesel replacement of up to $90 \%$ could be attained. The use of natural gas in automotive engines is expected to accelerate in the coming years due to the stringent regulations on liquid-fuel-based engines and the emergence of the latest strategies in fueling systems and combustion mechanisms.

Author Contributions: F.Y.H. and G.T.C. conceived the idea and developed the review work; A.R.A.A. contributed by reading and revising the manuscript.

Funding: Financial support was provided by Universiti Malaysia Pahang through the research grant number RDU160393

Acknowledgments: The authors would like to extend their acknowledgment to the INTI International University, Universiti Teknologi PETRONAS, and Universiti Malaysia Pahang for their facilities and financial support.

Conflicts of Interest: The authors declare no conflict of interest. The founding sponsors had no role in the design of the study; in the collection, analyses, or interpretation of data; in the writing of the manuscript, and in the decision to publish the results.

\section{References}

1. Hesterberg, T.; Bunn, W.; Lapin, C. An evaluation of criteria for selecting vehicles fueled with diesel or compressed natural gas. Sustain. Sci. Pract. Policy 2009, 5, 20-30. [CrossRef]

2. Thipse, S.S.; Sonawane, S.B.; D'Souza, A.F.; Rairikar, S.D.; Kavathekar, K.K.; Marathe, N.V. Injection Strategies, Optimization and Simulation Techniques on DI CNG Technology; SAE Technical Paper No. 2015-26-0046; SAE International: Warrendale, PA, USA, 2015.

3. Soldo, B.; Potočnik, P.; Šimunović, G.; Šarić, T.; Govekar, E. Improving the residential natural gas consumption forecasting models by using solar radiation. Energy Build. 2014, 69, 498-506. [CrossRef]

4. Yue, T.; Chai, F.; Hu, J.; Jia, M.; Bao, X.; Li, Z.; He, L.; Zu, L. Gaseous emissions from compressed natural gas buses in urban road and highway tests in China. J. Environ. Sci. 2016, 48, 193-199. [CrossRef] [PubMed]

5. Ahmadi, P.; Chapoy, A.; Tohidi, B. Density, speed of sound and derived thermodynamic properties of a synthetic natural gas. J. Nat. Gas Sci. Eng. 2017, 40, 249-266. [CrossRef]

6. AFDC. Natural gas vehicles. In Alternative Fuels Data Center; US Department of Energy: Washington, DC, USA, 2017.

7. FMI. Automotive natural gas vehicle market: Global industry analysis and opportunity assessment 2015-2025. In Future Market Insites; FMI: Washington, DC, USA, 2017. 
8. Bhandari, K.; Bansal, A.; Shukla, A.; Khare, M. Performance and emissions of natural gas fueled internal combustion engine: A review. J. Sci. Ind. Res. 2005, 64, 333-338.

9. Cho, H.M.; He, B.-Q. Spark ignition natural gas engines-A review. Energy Convers. Manag. 2007, 48, 608-618. [CrossRef]

10. Bakar, R.; Ismail, A.R. Green engines development using compressed natural gas as an alternative fuel: A review. Am. J. Environ. Sci. 2009, 5, 1-11.

11. Semin, R.A.B. A technical review of compressed natural gas as an alternative fuel for internal combustion engines. Am. J. Eng. Appl. Sci 2008, 1, 302-311.

12. Khan, M.I.; Yasmeen, T.; Khan, M.I.; Farooq, M.; Wakeel, M. Research progress in the development of natural gas as fuel for road vehicles: A bibliographic review (1991-2016). Renew. Sustain. Energy Rev. 2016, 66, 702-741. [CrossRef]

13. Matsuo, Y.; Yanagisawa, A.; Yamashita, Y. A global energy outlook to 2035 with strategic considerations for Asia and Middle East energy supply and demand interdependencies. Energy Strategy Rev. 2013, 2, 79-91. [CrossRef]

14. Su, M.; Zhang, M.; Lu, W.; Chang, X.; Chen, B.; Liu, G.; Hao, Y.; Zhang, Y. ENA-based evaluation of energy supply security: Comparison between the Chinese crude oil and natural gas supply systems. Renew. Sustain. Energy Rev. 2017, 72, 888-899. [CrossRef]

15. Mahmood, A.; Javaid, N.; Zafar, A.; Ali Riaz, R.; Ahmed, S.; Razzaq, S. Pakistan's overall energy potential assessment, comparison of LNG, TAPI and IPI gas projects. Renew. Sustain. Energy Rev. 2014, 31, 182-193. [CrossRef]

16. Shaikh, F.; Ji, Q.; Fan, Y.; Shaikh, P.H.; Uqaili, M.A. Modelling an optimal foreign natural gas import scheme for China. J. Nat. Gas Sci. Eng. 2017, 40, 267-276. [CrossRef]

17. Kerzmann, T.L.; Buxton, G.A.; Preisser, J. A computer model for optimizing the location of natural gas fueling stations. Sustain. Energy Technol. Assess. 2014, 7, 221-226. [CrossRef]

18. Peters, J.C. Natural gas and spillover from the us clean power plan into the Paris agreement. Energy Policy 2017, 106, 41-47. [CrossRef]

19. Pourhoseini, S.H.; Asadi, R. An experimental study on thermal and radiative characteristics of natural gas flame in different equivalence ratios by chemiluminescence and IR photography methods. J. Nat. Gas Sci. Eng. 2017, 40, 126-131. [CrossRef]

20. WEC. Energy resource: Gas. In World Energy; World Energy council: London, UK, 2016.

21. Wood, D.A.; Nwaoha, C.; Towler, B.F. Gas-to-liquids (GTL): A review of an industry offering several routes for monetizing natural gas. J. Nat. Gas Sci. Eng. 2012, 9, 196-208. [CrossRef]

22. Vivoda, V. LNG import diversification in Asia. Energy Strategy Rev. 2014, 2, 289-297. [CrossRef]

23. Zhang, Q.; Li, Z.; Wang, G.; Li, H. Study on the impacts of natural gas supply cost on gas flow and infrastructure deployment in China. Appl. Energy 2016, 162, 1385-1398. [CrossRef]

24. Kumar, S.; Kwon, H.-T.; Choi, K.-H.; Hyun Cho, J.; Lim, W.; Moon, I. Current status and future projections of LNG demand and supplies: A global prospective. Energy Policy 2011, 39, 4097-4104. [CrossRef]

25. Kumar, S.; Kwon, H.-T.; Choi, K.-H.; Lim, W.; Cho, J.H.; Tak, K.; Moon, I. LNG: An eco-friendly cryogenic fuel for sustainable development. Appl. Energy 2011, 88, 4264-4273. [CrossRef]

26. Ruble, I. European union energy supply security: The benefits of natural gas imports from the eastern Mediterranean. Energy Policy 2017, 105, 341-353. [CrossRef]

27. Al-Sobhi, S.A.; Elkamel, A. Simulation and optimization of natural gas processing and production network consisting of LNG, GTL, and methanol facilities. J. Nat. Gas Sci. Eng. 2015, 23, 500-508. [CrossRef]

28. BP. BP Statistical Review of World Energy; BP: London, UK, 2016.

29. Siddig, K.; Grethe, H. No more gas from Egypt? Modeling offshore discoveries and import uncertainty of natural gas in Israel. Appl. Energy 2014, 136, 312-324. [CrossRef]

30. Kang, Z. Natural gas supply-demand situation and prospect in China. Nat. Gas Ind. B 2014, 1, 103-112. [CrossRef]

31. Leather, D.T.B.; Bahadori, A.; Nwaoha, C.; Wood, D.A. A review of Australia's natural gas resources and their exploitation. J. Nat. Gas Sci. Eng. 2013, 10, 68-88. [CrossRef]

32. Economides, M.J.; Oligney, R.E.; Lewis, P.E. U.S. Natural gas in 2011 and beyond. J. Nat. Gas Sci. Eng. 2012, 8, 2-8. [CrossRef] 
33. Song, Y.; Cheng, C.; Zhao, J.; Zhu, Z.; Liu, W.; Yang, M.; Xue, K. Evaluation of gas production from methane hydrates using depressurization, thermal stimulation and combined methods. Appl. Energy 2015, 145, 265-277. [CrossRef]

34. Chong, Z.R.; Yang, S.H.B.; Babu, P.; Linga, P.; Li, X.-S. Review of natural gas hydrates as an energy resource: Prospects and challenges. Appl. Energy 2016, 162, 1633-1652. [CrossRef]

35. Soldo, B. Forecasting natural gas consumption. Appl. Energy 2012, 92, 26-37. [CrossRef]

36. Fei, Q.; Guarnieri, M.T.; Tao, L.; Laurens, L.M.L.; Dowe, N.; Pienkos, P.T. Bioconversion of natural gas to liquid fuel: Opportunities and challenges. Biotechnol. Adv. 2014, 32, 596-614. [CrossRef] [PubMed]

37. Bahadori, A. Chapter 1-overview of natural gas resources. In Natural Gas Processing; Gulf Professional Publishing: Boston, MA, USA, 2014; pp. 1-22.

38. Shaffer, B. Natural gas supply stability and foreign policy. Energy Policy 2013, 56, 114-125. [CrossRef]

39. Anderson, B.E.; Uz, V. Compressed natural gas as a feasible replacement fuel for U.S. Transportation. J. Def. Model. Simul. 2014, 12, 67-78. [CrossRef]

40. Nwaoha, C.; Wood, D.A. A review of the utilization and monetization of Nigeria's natural gas resources: Current realities. J. Nat. Gas Sci. Eng. 2014, 18, 412-432. [CrossRef]

41. Egging, R.; Pichler, A.; Kalvø, Ø.I.; Walle-Hansen, T.M. Risk aversion in imperfect natural gas markets. Eur. J. Oper. Res. 2017, 259, 367-383. [CrossRef]

42. Honore, A. European Natural Gas Demand, Supply, and Pricing: Cycles, Seasons, and the Impact of LNG Price Arbitrage; Oxford University Press: Oxford, UK, 2011.

43. Dilaver, Ö.; Dilaver, Z.; Hunt, L.C. What drives natural gas consumption in Europe? Analysis and projections. J. Nat. Gas Sci. Eng. 2014, 19, 125-136. [CrossRef]

44. Eurogas. Eurogas Statistical Report 2015; Eurogas: Brussels, Belgium, 2016.

45. Holz, F.; von Hirschhausen, C.; Kemfert, C. A strategic model of European gas supply (gasmod). Energy Econ. 2008, 30, 766-788. [CrossRef]

46. Aloui, R.; Aïssa, M.S.B.; Hammoudeh, S.; Nguyen, D.K. Dependence and extreme dependence of crude oil and natural gas prices with applications to risk management. Energy Econ. 2014, 42, 332-342. [CrossRef]

47. Ríos-Mercado, R.Z.; Borraz-Sánchez, C. Optimization problems in natural gas transportation systems: A state-of-the-art review. Appl. Energy 2015, 147, 536-555. [CrossRef]

48. Kafood, A.H. CNG application in Qatar. In Proceedings of the International Petroleum Technology Conference (IPTC 2014), Bangkok, Thailand, 14-16 November 2014.

49. Wang, Q.; Chen, X.; Jha, A.N.; Rogers, H. Natural gas from shale formation-The evolution, evidences and challenges of shale gas revolution in united states. Renew. Sustain. Energy Rev. 2014, 30, 1-28. [CrossRef]

50. Brigida, M. The switching relationship between natural gas and crude oil prices. Energy Econ. 2014, 43, 48-55. [CrossRef]

51. Koh, D.-Y.; Kang, H.; Lee, J.-W.; Park, Y.; Kim, S.-J.; Lee, J.; Lee, J.Y.; Lee, H. Energy-efficient natural gas hydrate production using gas exchange. Appl. Energy 2016, 162, 114-130. [CrossRef]

52. de Melo-Martín, I.; Hays, J.; Finkel, M.L. The role of ethics in shale gas policies. Sci. Total Environ. 2014, 470-471, 1114-1119. [CrossRef] [PubMed]

53. Fernández, R.; Palazuelos, E. The future of Russian gas exports to east Asia: Feasibility and market implications. Futures 2011, 43, 1069-1081. [CrossRef]

54. Asche, F.; Oglend, A.; Osmundsen, P. Gas versus oil prices the impact of shale gas. Energy Policy 2012, 47, 117-124. [CrossRef]

55. Bazilian, M.; Brandt, A.R.; Billman, L.; Heath, G.; Logan, J.; Mann, M.; Melaina, M.; Statwick, P.; Arent, D.; Benson, S.M. Ensuring benefits from north American shale gas development: Towards a research agenda. J. Unconv. Oil Gas Resour. 2014, 7, 71-74. [CrossRef]

56. US Energy Information Administration. International Energy Outlook 2016; US Energy Information Administration: Washington, DC, USA, 2016.

57. Moryadee, S.; Gabriel, S.A.; Avetisyan, H.G. Investigating the potential effects of U.S. LNG exports on global natural gas markets. Energy Strategy Rev. 2014, 2, 273-288. [CrossRef]

58. Fukui, R.; Greenfield, C.; Pogue, K.; van der Zwaan, B. Experience curve for natural gas production by hydraulic fracturing. Energy Policy 2017, 105, 263-268. [CrossRef]

59. Arora, V.; Cai, Y. U.S. Natural gas exports and their global impacts. Appl. Energy 2014, 120, 95-103. [CrossRef] 
60. Heidari, H.; Katircioglu, S.T.; Saeidpour, L. Natural gas consumption and economic growth: Are we ready to natural gas price liberalization in Iran? Energy Policy 2013, 63, 638-645. [CrossRef]

61. Clark, D.E.; Dybicz, C.; Hanson, A.; Nourzad, F. "No shut-off” policies and natural gas consumption. Resour. Energy Econ. 2017, 48, 19-29. [CrossRef]

62. Dong, X.; Pi, G.; Ma, Z.; Dong, C. The reform of the natural gas industry in the Republic of China. Renew. Sustain. Energy Rev. 2017, 73, 582-593. [CrossRef]

63. Cabalu, H. Indicators of security of natural gas supply in Asia. Energy Policy 2010, 38, 218-225. [CrossRef]

64. Ogunlowo, O.O.; Bristow, A.L.; Sohail, M. Developing compressed natural gas as an automotive fuel in Nigeria: Lessons from international markets. Energy Policy 2015, 76, 7-17. [CrossRef]

65. Von Rosenstiel, D.P.; Heuermann, D.F.; Hüsig, S. Why has the introduction of natural gas vehicles failed in Germany?-Lessons on the role of market failure in markets for alternative fuel vehicles. Energy Policy 2015, 78, 91-101. [CrossRef]

66. International Energy Agency. Mid Term Market Report 2015; International Energy Agency: Paris, France, 2015.

67. Xian, H.; Karali, B.; Colson, G.; Wetzstein, M.E. Diesel or compressed natural gas? A real options evaluation of the U.S. Natural gas boom on fuel choice for trucking fleets. Energy 2015, 90, 1342-1348. [CrossRef]

68. Curran, S.J.; Wagner, R.M.; Graves, R.L.; Keller, M.; Green, J.B., Jr. Well-to-wheel analysis of direct and indirect use of natural gas in passenger vehicles. Energy 2014, 75, 194-203. [CrossRef]

69. Arteconi, A.; Polonara, F. LNG as vehicle fuel and the problem of supply: The Italian case study. Energy Policy 2013, 62, 503-512. [CrossRef]

70. Wang, H.; Fang, H.; Yu, X.; Wang, K. Development of natural gas vehicles in China: An assessment of enabling factors and barriers. Energy Policy 2015, 85, 80-93. [CrossRef]

71. Paltsev, S.; Zhang, D. Natural gas pricing reform in China: Getting closer to a market system? Energy Policy 2015, 86, 43-56. [CrossRef]

72. Hao, H.; Wang, H.; Ouyang, M.; Cheng, F. Vehicle survival patterns in China. Sci. Chin. Technol. Sci. 2011, 54, 625-629. [CrossRef]

73. Hao, H.; Geng, Y.; Li, W.; Guo, B. Energy consumption and GHG emissions from China's freight transport sector: Scenarios through 2050. Energy Policy 2015, 85, 94-101. [CrossRef]

74. Ma, L.; Geng, J.; Li, W.; Liu, P.; Li, Z. The development of natural gas as automotive fuel in china. Energy Policy 2013, 62, 531-539. [CrossRef]

75. Li, J.; Dong, X.; Shangguan, J.; Hook, M. Forecasting the growth of china's natural gas consumption. Energy 2011, 36, 1380-1385. [CrossRef]

76. Halova Wolfe, M.; Rosenman, R. Bidirectional causality in oil and gas markets. Energy Econ. 2014, 42, 325-331. [CrossRef]

77. Khan, M.I.; Yasmin, T. Development of natural gas as a vehicular fuel in Pakistan: Issues and prospects. J. Nat. Gas Sci. Eng. 2014, 17, 99-109. [CrossRef]

78. Perry, D. Current Natural Gas Vehicle Statistics; NGV Global: Auckland, New Zealand, 2017.

79. Holmala, J.; Isaksson, J. Metso-Supplied World's Largest Biomass Gasification Plant Inaugurated in Finland; Metso Corporation: Helsinki, Finland, 2013.

80. Engerer, H.; Horn, M. Natural gas vehicles: An option for Europe. Energy Policy 2010, 38, 1017-1029. [CrossRef]

81. Kuby, M.; Capar, I.; Kim, J.-G. Efficient and equitable transnational infrastructure planning for natural gas trucking in the European union. Eur. J. Oper. Res. 2017, 257, 979-991. [CrossRef]

82. Osorio-Tejada, J.L.; Llera-Sastresa, E.; Scarpellini, S. Liquefied natural gas: Could it be a reliable option for road freight transport in the EU? Renew. Sustain. Energy Rev. 2017, 71, 785-795. [CrossRef]

83. Bilgin, M. Geopolitics of European natural gas demand: Supplies from Russia, Caspian and the Middle East. Energy Policy 2009, 37, 4482-4492. [CrossRef]

84. Hao, H.; Liu, Z.; Zhao, F.; Li, W. Natural gas as vehicle fuel in China: A review. Renew. Sustain. Energy Rev. 2016, 62, 521-533. [CrossRef]

85. DeVos, K. A Review of Compressed Natural Gas as a Viable Alternative Fuel for Passenger Vehicle, Spark Ignition, Four-Stroke Engines; Rensselaer Polytechnic Institute: Troy, NY, USA, 2014.

86. Idris, S.; Abu Baker, R. An overview of compressed natural gas as an alternative fuel and Malaysian scenario. Eur. J. Sci. Res. 2009, 34, 6-15. 
87. Yeh, S. An empirical analysis on the adoption of alternative fuel vehicles: The case of natural gas vehicles. Energy Policy 2007, 35, 5865-5875. [CrossRef]

88. Chen, S.P.; Xie, G.F.; Li, Q.Y.; Chang, K. Comparison among LNG, CNG and 1-CNG filling stations. Gas Heat 2007, 7, 006.

89. Sharafian, A.; Talebian, H.; Blomerus, P.; Herrera, O.; Mérida, W. A review of liquefied natural gas refueling station designs. Renew. Sustain. Energy Rev. 2017, 69, 503-513. [CrossRef]

90. Gashighway. Available online: http:/ / www.gashighway.net/ (accessed on 17 June 2017).

91. Commission, E. Eu Launches Clean Fuel Strategy; European Commission: Bruxelles, Belgium, 2013.

92. Chala, G.; Aziz, A.; Hagos, F. Combined effect of boost pressure and injection timing on the performance and combustion of CNG in a di spark ignition engine. Int. J. Automot. Technol. 2017, 18, 85-96. [CrossRef]

93. Yang, B.; Xi, C.; Wei, X.; Zeng, K.; Lai, M.-C. Parametric investigation of natural gas port injection and diesel pilot injection on the combustion and emissions of a turbocharged common rail dual-fuel engine at low load. Appl. Energy 2015, 143, 130-137. [CrossRef]

94. McTaggart-Cowan, G.P.; Jones, H.L.; Rogak, S.N.; Bushe, W.K.; Hill, P.G.; Munshi, S.R. The effects of high-pressure injection on a compression-ignition, direct injection of natural gas engine. J. Eng. Gas Turbines Power 2006, 129, 579-588. [CrossRef]

95. Amrouche, F.; Benzaoui, A.; Harouadi, F.; Mahmah, B.; Belhamel, M. Compressed natural gas: The new alternative fuel for the algerian transportation sector. Procedia Eng. 2012, 33, 102-110. [CrossRef]

96. Srinivasan, K.K.; Krishnan, S.R.; Singh, S.; Midkiff, K.C.; Bell, S.R.; Gong, W.; Fiveland, S.B.; Willi, M. The advanced injection low pilot ignited natural gas engine: A combustion analysis. J. Eng. Gas Turbines Power 2006, 128, 213-218. [CrossRef]

97. Korakianitis, T.; Namasivayam, A.; Crookes, R. Natural-gas fueled spark-ignition (SI) and compression-ignition (ci) engine performance and emissions. Prog. Energy Combust. Sci. 2011, 37, 89-112. [CrossRef]

98. De Carvalho, R.D.B.; Valle, R.M.; de Magalhães, F.E. Performance and Emission Analysis of the Turbocharged Spark-Ignition Engine Converted to Natural Gas; 0148-7191; SAE Technical Paper; SAE International: Warrendale, PA, USA, 2003.

99. Jarrahian, A.; Aghel, B.; Heidaryan, E. On the viscosity of natural gas. Fuel 2015, 150, 609-618. [CrossRef]

100. Ocelík, P.; Osička, J. The framing of unconventional natural gas resources in the foreign energy policy discourse of the Russian federation. Energy Policy 2014, 72, 97-109. [CrossRef]

101. Liu, Z.; Norbeck, J.M.; Raju, A.S.K.; Kim, S.; Park, C.S. Synthetic natural gas production by sorption enhanced steam hydrogasification based processes for improving ch4 yield and mitigating $\mathrm{CO}_{2}$ emissions. Energy Convers. Manag. 2016, 126, 256-265. [CrossRef]

102. Esfahani, S.; Baselizadeh, S.; Hemmati-Sarapardeh, A. On determination of natural gas density: Least square support vector machine modeling approach. J. Nat. Gas Sci. Eng. 2015, 22, 348-358. [CrossRef]

103. Heidaryan, E.; Moghadasi, J.; Salarabadi, A. A new and reliable model for predicting methane viscosity at high pressures and high temperatures. J. Nat. Gas Chem. 2010, 19, 552-556. [CrossRef]

104. Yousefi, S.H.; Azamifard, A.; Hosseini, S.-A.; Shamsoddini, M.-J.; Alizadeh, N. Toward a predictive model for predicting viscosity of natural and hydrocarbon gases. J. Nat. Gas Sci. Eng. 2014, 20, 147-154. [CrossRef]

105. Skylogianni, E.; Novak, N.; Louli, V.; Pappa, G.; Boukouvalas, C.; Skouras, S.; Solbraa, E.; Voutsas, E. Measurement and prediction of dew points of six natural gases. Fluid Phase Equilib. 2016, 424, 8-15. [CrossRef]

106. Mesquita, F.; Feitosa, F.; Do Carmo, F.; de Santiago-Aguiar, R.; de Sant'Ana, H. Viscosities and viscosity deviations of binary mixtures of biodiesel + petrodiesel (or n-hexadecane) at different temperatures. Braz. J. Chem. Eng. 2012, 29, 653-664. [CrossRef]

107. Walsh, M.P. Property of fuels. In Car Lines; Michael, P., Ed.; Car Lines: Arlington, ND, USA, 2006.

108. Acevedo, H.; Mantilla, J. Performance and emissions of a heavy duty diesel engine fuelled with palm oil biodiesel and premium diesel. Dyna 2011, 78, 152-158.

109. Chong, C.T.; Hochgreb, S. Measurements of laminar flame speeds of liquid fuels: Jet-a1, diesel, palm methyl esters and blends using particle imaging velocimetry (PIV). Proc. Combust. Inst. 2011, 33, 979-986. [CrossRef]

110. Dirrenberger, P.; Glaude, P.-A.; Bounaceur, R.; Le Gall, H.; da Cruz, A.P.; Konnov, A.; Battin-Leclerc, F. Laminar burning velocity of gasolines with addition of ethanol. Fuel 2014, 115, 162-169. [CrossRef] 
111. Glaude, P.-A.; Fournet, R.; Bounaceur, R.; Molière, M. Adiabatic flame temperature from biofuels and fossil fuels and derived effect on $\mathrm{NO}_{\mathrm{x}}$ emissions. Fuel Process. Technol. 2010, 91, 229-235. [CrossRef]

112. Ahlvik, P. Natural gas. In Diesel NET; ECOpoint Inc.: Mississauga, ON, Canada, 2003.

113. Mishra, S. Biogas from Wholesale Vegetable and Fruit Market Waste in the Indian Cities: Truely Sustainable and Renewable Transport Fuel; Green Cosmos Energy Solutions Pvt. Ltd.: Bangalore, India, 2012.

114. Mazyan, W.; Ahmadi, A.; Ahmed, H.; Hoorfar, M. Market and technology assessment of natural gas processing: A review. J. Nat. Gas Sci. Eng. 2016, 30, 487-514. [CrossRef]

115. Berstad, D.; Nekså, P.; Anantharaman, R. Low-temperature $\mathrm{CO}_{2}$ removal from natural gas. Energy Procedia 2012, 26, 41-48. [CrossRef]

116. Peters, L.; Hussain, A.; Follmann, M.; Melin, T.; Hägg, M.B. $\mathrm{CO}_{2}$ removal from natural gas by employing amine absorption and membrane technology—A technical and economical analysis. Chem. Eng. J. 2011, 172, 952-960. [CrossRef]

117. Rufford, T.E.; Smart, S.; Watson, G.C.Y.; Graham, B.F.; Boxall, J.; Diniz da Costa, J.C.; May, E.F. The removal of $\mathrm{CO}_{2}$ and $\mathrm{N}_{2}$ from natural gas: A review of conventional and emerging process technologies. J. Pet. Sci. Eng. 2012, 94-95, 123-154. [CrossRef]

118. Alcheikhhamdon, Y.; Hoorfar, M. Natural gas quality enhancement: A review of the conventional treatment processes, and the industrial challenges facing emerging technologies. J. Nat. Gas Sci. Eng. 2016, 34, 689-701. [CrossRef]

119. Faramawy, S.; Zaki, T.; Sakr, A.A.E. Natural gas origin, composition, and processing: A review. J. Nat. Gas Sci. Eng. 2016, 34, 34-54. [CrossRef]

120. Ahmadian Behrooz, H. Managing demand uncertainty in natural gas transmission networks. J. Nat. Gas Sci. Eng. 2016, 34, 100-111. [CrossRef]

121. Nagayama, D.; Horita, M. A network game analysis of strategic interactions in the international trade of russian natural gas through ukraine and belarus. Energy Econ. 2014, 43, 89-101. [CrossRef]

122. Qu, Z.; Wang, Y.; Yue, H.; An, Y.; Wu, L.; Zhou, W.; Wang, H.; Su, Z.; Li, J.; Zhang, Y. Study on the natural gas pipeline safety monitoring technique and the time-frequency signal analysis method. J. Loss Prev. Process Ind. 2017, 47, 1-9. [CrossRef]

123. Üster, H.; Dilaveroğlu, Ş. Optimization for design and operation of natural gas transmission networks. Appl. Energy 2014, 133, 56-69. [CrossRef]

124. Ertas, A.; Anderson, E. Review of methanol and compressed natural gas (CNG) as alternative for transportation fuels. J. Energy Resour. Technol 1991, 113, 101. [CrossRef]

125. Koza, D.F.; Ropke, S.; Boleda Molas, A. The liquefied natural gas infrastructure and tanker fleet sizing problem. Transp. Res. Part E Logist. Transp. Rev. 2017, 99, 96-114. [CrossRef]

126. Shi, G.-H.; Jing, Y.-Y.; Wang, S.-L.; Zhang, X.-T. Development status of liquefied natural gas industry in china. Energy Policy 2010, 38, 7457-7465. [CrossRef]

127. Wood, D.A. A review and outlook for the global LNG trade. J. Nat. Gas Sci. Eng. 2012, 9, 16-27. [CrossRef]

128. Vivoda, V. Natural gas in Asia: Trade, markets and regional institutions. Energy Policy 2014, 74, 80-90. [CrossRef]

129. Dorigoni, S.; Graziano, C.; Pontoni, F. Can LNG increase competitiveness in the natural gas market? Energy Policy 2010, 38, 7653-7664. [CrossRef]

130. Dorigoni, S.; Portatadino, S. LNG development across Europe: Infrastructural and regulatory analysis. Energy Policy 2008, 36, 3366-3373. [CrossRef]

131. Erdős, P. Have oil and gas prices got separated? Energy Policy 2012, 49, 707-718. [CrossRef]

132. Wang, X.; Marongiu Porcu, M. The Potential of Compressed Natural Gas Transport in Asia. In Proceedings of the International Petroleum Technology Conference, Kuala Lumpur, Malaysia, 3-5 December 2008.

133. Hafner, M.; Karbuz, S.; Esnault, B.; Andaloussi, H.E. Long-term natural gas supply to Europe: Import potential, infrastructure needs and investment promotion. Energy Environ. 2008, 19, 1131-1153. [CrossRef]

134. Talus, K. Long-term natural gas contracts and antitrust law in the European union and the united states. J. World Energy Law Bus. 2011, 4, 260-315i. [CrossRef]

135. Castillo, L.; Majzoub Dahouk, M.; Di Scipio, S.; Dorao, C.A. Conceptual analysis of the precooling stage for lng processes. Energy Convers. Manag. 2013, 66, 41-47. [CrossRef]

136. Zhou, S.; Gao, J.; Yang, Y.; Li, B.; Petro, P. Development, problems and market share of the LNG industry in China. Int. Pet. Econ. 2013, $6,3$. 
137. Wang, Z.; Rao, L.; Yang, Y.; Gao, H. Natural gas vehicles will develop greatly in china. In Proceedings of the International Petroleum Technology Conference (IPTC 2013), Beijing, China, 26-28 March 2013.

138. Medlock, K.B.; Jaffe, A.M.; O'Sullivan, M. The global gas market, LNG exports and the shifting us geopolitical presence. Energy Strategy Rev. 2014, 5, 14-25. [CrossRef]

139. Paltsev, S. Scenarios for Russia's natural gas exports to 2050. Energy Econ. 2014, 42, 262-270. [CrossRef]

140. Birol, F. G7 energy ministerial meeting. In Proceedings of the G7 Energy Ministerial Meeting, Rome, Italy, 9-10 April 2017.

141. Thomas, S.; Dawe, R.A. Review of ways to transport natural gas energy from countries which do not need the gas for domestic use. Energy 2003, 28, 1461-1477. [CrossRef]

142. Wang, X.; Economides, A.M.; Porcu, M.M.; Economides, M.J. Compressed natural gas for Indonesia. In Proceedings of the Asia Pacific Oil and Gas Conference \& Exhibition, Jakarta, Indonesia, 4-6 August 2009.

143. Khan, M.I.; Yasmin, T.; Shakoor, A. Technical overview of compressed natural gas (CNG) as a transportation fuel. Renew. Sustain. Energy Rev. 2015, 51, 785-797. [CrossRef]

144. Melaina, M.; Bremson, J. Refueling availability for alternative fuel vehicle markets: Sufficient urban station coverage. Energy Policy 2008, 36, 3233-3241. [CrossRef]

145. Patrizio, P.; Leduc, S.; Chinese, D.; Dotzauer, E.; Kraxner, F. Biomethane as transport fuel—A comparison with other biogas utilization pathways in northern Italy. Appl. Energy 2015, 157, 25-34. [CrossRef]

146. Salman, C.A.; Schwede, S.; Thorin, E.; Yan, J. Enhancing biomethane production by integrating pyrolysis and anaerobic digestion processes. Appl. Energy 2017, 204, 1074-1083. [CrossRef]

147. Görling, M.; Larsson, M.; Alvfors, P. Bio-methane via fast pyrolysis of biomass. Appl. Energy 2013, 112, 440-447. [CrossRef]

148. Ullah Khan, I.; Hafiz Dzarfan Othman, M.; Hashim, H.; Matsuura, T.; Ismail, A.F.; Rezaei-DashtArzhandi, M.; Wan Azelee, I. Biogas as a renewable energy fuel-A review of biogas upgrading, utilisation and storage. Energy Convers. Manag. 2017, 150, 277-294. [CrossRef]

149. Patterson, T.; Esteves, S.; Dinsdale, R.; Guwy, A. An evaluation of the policy and techno-economic factors affecting the potential for biogas upgrading for transport fuel use in the UK. Energy Policy 2011, 39, 1806-1816. [CrossRef]

150. Augelletti, R.; Conti, M.; Annesini, M.C. Pressure swing adsorption for biogas upgrading. A new process configuration for the separation of biomethane and carbon dioxide. J. Clean. Prod. 2017, 140, 1390-1398. [CrossRef]

151. Pellegrini, L.A.; De Guido, G.; Langé, S. Biogas to liquefied biomethane via cryogenic upgrading technologies. Renew. Energy 2017, 124, 75-83. [CrossRef]

152. Götz, M.; Lefebvre, J.; Mörs, F.; McDaniel Koch, A.; Graf, F.; Bajohr, S.; Reimert, R.; Kolb, T. Renewable power-to-gas: A technological and economic review. Renew. Energy 2016, 85, 1371-1390. [CrossRef]

153. Castellani, B.; Rinaldi, S.; Morini, E.; Nastasi, B.; Rossi, F. Flue gas treatment by power-to-gas integration for methane and ammonia synthesis - energy and environmental analysis. Energy Convers. Manag. 2018, 171, 626-634. [CrossRef]

154. Hassan, M.H.; Kalam, M.A.; Mahlia, T.I.; Aris, I.; Nizam, M.K.; Abdullah, S.; Ali, Y. Experimental test of a new compressed natural gas direct injection engine. Energy Fuels 2009, 23, 4981-4987. [CrossRef]

155. Heywood, J.B. Internal Combustion Engine Fundamentals; McGraw Hill International: New York, NY, USA, 1988.

156. Arcoumanis, C.; Kamimoto, T. Flow and Combustion in Reciprocating Engines; Springer Science \& Business Media: Berlin, Germany, 2009.

157. Willems, H.; Sierens, R. Modeling the initial growth of the plasma and flame kernel in SI engines. Trans. Am. Soc. Mech. Eng. J. Eng. Gas Turbines Power 2003, 125, 479-484. [CrossRef]

158. Aleiferis, P.G.; Taylor, A.M.; Whitelaw, J.H.; Ishii, K.; Urata, Y. Cyclic Variations of Initial Flame Kernel Growth in a Honda Vtec-E Lean-Burn Spark-Ignition Engine; SAE Technical Paper 0148-7191; SAE International: Warrendale, PA, USA, 2000.

159. Hagos, F. Combustion, Performance and Emissions Characteristics of Imitated Syngases in Direct-Injection Sparkigntion Engine. Ph.D. Thesis, Universiti Teknologi Petronas, Seri Iskandar, Malaysia, 2013.

160. Gharehghani, A.; Hosseini, R.; Mirsalim, M.; Yusaf, T.F. A comparative study on the first and second law analysis and performance characteristics of a spark ignition engine using either natural gas or gasoline. Fuel 2015, 158, 488-493. [CrossRef] 
161. Ou, X.; Zhang, X. Life-cycle analyses of energy consumption and GHG emissions of natural gas-based alternative vehicle fuels in china. J. Energy 2013, 2013. [CrossRef]

162. Aziz, A.R.A.; Shahzad, R. Combustion analysis of a CNG direct injection spark ignition engine. Int. J. Automot. Mech. Eng. 2010, 2, 157-170. [CrossRef]

163. Chandra, R.; Vijay, V.; Subbarao, P.; Khura, T. Performance evaluation of a constant speed IC engine on CNG, methane enriched biogas and biogas. Appl. Energy 2011, 88, 3969-3977. [CrossRef]

164. Sonthalia, A.; Rameshkumar, C.; Sharma, U.; Punganur, A.; Abbas, S. Combustion and performance characteristics of a small spark ignition engine fuelled with HCNG. J. Eng. Sci. Technol. 2015, 10, 404-419.

165. Jahirul, M.I.; Masjuki, H.; Saidur, R.; Kalam, M.; Jayed, M.; Wazed, M. Comparative engine performance and emission analysis of CNG and gasoline in a retrofitted car engine. Appl. Therm. Eng. 2010, 30, 2219-2226. [CrossRef]

166. Rezapour, K.; Mason, B.; Wood, A.S.; Ebrahimi, M. Bi-fuel SI engine model for analysis and optimization. Univ. J. Mech. Eng. 2014, 2, 71-82. [CrossRef]

167. Poulton, M.L. Alternative Fuels for Road Vehicles; WIT Press: Southampton, UK, 1994.

168. Ouellette, P. High pressure direct injection (HPDI) of natural gas in diesel engines. In Proceedings of the ANGVA 2000 Conference, Yokohama, Japan, 7-10 November 2000.

169. Tadesse, G.; Aziz, A.R.A. Effect of Boost Pressure on Engine Performance and Exhaust Emissions in Direct-Injection Compressed Natural Gas CNG-DI) Spark Ignition Engine; SAE Technical Paper No. 2009-32-0135; SAE International: Warrendale, PA, USA, 2009.

170. Tadesse, G. Effect of Boost Pressure on Performance, Combustion and Exhaust Emissions in Direct Injection Compressed Natural Gas (CNG) Engine. Master's Thesis, University Teknologi Petronas, Perak, Malaysia, 2009.

171. d'Ambrosio, S.; Spessa, E.; Vassallo, A.; Ferrera, M.; Peletto, C. Experimental Investigation of Fuel Consumption, Exhaust Emissions and Heat Release of a Small-Displacement Turbocharged CNG Engine; SAE Technical Paper 0148-7191; SAE International: Warrendale, PA, USA, 2006.

172. Li, H. An Experimental and Analytical Examination of Gas Fuelled Spark Ignition Engine-Performance and Combustion; University of Calgary: Calgary, AB, Canada, 2004.

173. Reynolds, C.C.O.; Evans, R.L.; Andreassi, L.; Cordiner, S.; Mulone, V. The Effect of Varying the Injected Charge Stoichiometry in a Partially Stratified Charge Natural Gas Engine; SAE Technical Paper 0148-7191; SAE International: Warrendale, PA, USA, 2005.

174. Da Silveira, B.H.; Benvenuti, L.H.; Werninghaus, E.; Coelho, E.P.; Silva, C.D.; de Oliveira, F.R.; Silva, J.C.S. Development of a Concept Vehicle for Compressed Natural Gas; SAE Technical Paper 0148-7191; SAE International: Warrendale, PA, USA, 2004.

175. Durell, E.; Allen, J.; Law, D.; Heath, J. Installation and Development of a Direct Injection System for a Bi-Fuel Gasoline and Compressed Natural Gas Engine. In Proceeding of the ANGVA 2000 Conference, Yokohama, Japan, 18-21 July 2000.

176. Abid, F.H. Comparison of performance characteristics of $\mathrm{ng}$ and gasoline-fuelled single cylinder SI engine. Int. J. Comput. Appl. Sci. 2016, 1, 13-20.

177. Melaika, M.; Dahlander, P. Experimental Investigation of Methane Direct Injection with Stratified Charge Combustion in Optical SI Single Cylinder Engine; SAE Technical Paper 0148-7191; SAE International: Warrendale, PA, USA, 2016.

178. Ilves, R.; Olt, J. Study of prior art of spark ignition engine fuel supply system. Argon. Res. 2012, 10, 55-74.

179. Stone, R. Introduction to Internal Combustion Engines; Palgrave Macmillan: London, UK, 2012.

180. Mello, P.; Pelliza, G.; Cataluña, R.; da Silva, R. Evaluation of the maximum horsepower of vehicles converted for use with natural gas fuel. Fuel 2006, 85, 2180-2186. [CrossRef]

181. Tuner, M. Combustion of Alternative Vehicle Fuels in Internal Combustion Engines; Report within Project; A Pre-Study to Prepare for Interdisciplinary Research on Future Alternative Transportation Fuels; Financed by The Swedish Energy Agency; Lund University: Lund, Sweden, 2016.

182. Nice, K. How Fuel Injection Systems Work. 2001. Available online: https://www.howstuffworks.com/ (accessed on 17 June 2017).

183. Loukanine, V.N.; Khatchiyan, A.S.; Shishlov, I.G.; Khamidullin, R.K. Analysis of different ways to develop low-emission natural gas engines. In Proceedings of the NGV 2000, Yokohama, Japan, 17-19 October 2000.

184. Czerwinski, J.; Comte, P.; Zimmerli, Y. Investigations of the Gas Injection System on a HD-CNG-Engine; SAE Technical Paper 0148-7191; SAE International: Warrendale, PA, USA, 2003. 
185. Choi, M.; Lee, S.; Park, S. Numerical and experimental study of gaseous fuel injection for CNG direct injection. Fuel 2015, 140, 693-700. [CrossRef]

186. Chiodi, M.; Berner, H.-J.; Bargende, M. Investigation on Different Injection Strategies in a Direct-Injected Turbocharged CNG-Engine; SAE Technical Paper 0148-7191; SAE International: Warrendale, PA, USA, 2006.

187. Cox, G.; DelVecchio, K.; Hays, W.; Hiltner, J.; Nagaraj, R.; Emmer, C. Development of a Direct-Injected Natural Gas Engine System for Heavy-Duty Vehicles; Caterpillar, Inc.: Peoria, IL, USA, 2000.

188. Hayashida, M.; Yamato, T.; Sekino, H.; Sugahara, K. Investigation of Performance and Fuel Distribution of a Direct Injection Gas Engine Using LIF Measurement; SAE Technical Paper 0148-7191; SAE International: Warrendale, PA, USA, 1999.

189. Hassaneen, A.E.; Varde, K.S.; Bawady, A.H.; Morgan, A.-A. A Study of the Flame Development and Rapid Burn Durations in a Lean-Burn Fuel Injected Natural Gas SI Engine; SAE Technical Paper 0148-7191; SAE International: Warrendale, PA, USA, 1998.

190. Heywood, J. Internal combustion ENGINE Fundamentals; McGraw-Hill Education: New York, NY, USA, 1988.

191. Achleitner, E.; Bäcker, H.; Funaioli, A. Direct Injection Systems for Otto Engines; SAE Technical Paper 0148-7191; SAE International: Warrendale, PA, USA, 2007.

192. Hagos, F.Y.; Aziz, A.R.A.; Sulaiman, S.A. Combustion characteristics of late injected CNG in a spark ignition engine under lean operating condition. J. Appl. Sci. 2012, 12, 2368. [CrossRef]

193. Sahari, B.B.; Ali, Y.; Ahmadun, F.L.-R.; Abdullah, S.; Hassan, M.H.; Aris, I.; Abdullah, M.A.; Ahmad, M.F.; Chelliah, V.; Taha, Z. Development of a prototype compressed natural gas direct injection vehicle-A Malaysian experience. In Proceedings of the 12th IANGV Conference and Exhibition, Rome, Italy; 9-12 May 2010.

194. Nijboer, M. The Contribution of Natural Gas Vehicles to Sustainable Transport; 2079-2581; International Energy Agency: Paris, France, 2010.

195. Kalam, M.; Masjuki, H. An experimental investigation of high performance natural gas engine with direct injection. Energy 2011, 36, 3563-3571. [CrossRef]

196. Zheng, J.; Wang, J.; Wang, B.; Huang, Z. Effect of the compression ratio on the performance and combustion of a natural-gas direct-injection engine. Proc. Inst. Mech. Eng. D-J. Automob. Eng. 2009, 223, 85-98. [CrossRef]

197. Ibrahim, A.; Bari, S. Effect of varying compression ratio on a natural gas SI engine performance in the presence of EGR. Energy Fuels 2009, 23, 4949-4956. [CrossRef]

198. Ramachandran, A.; Waghmare, A. Experimental investigation of the effect of compression ratio on the performance of a dedicated CNG engine. Int. Res. J. Eng. Technol. 2016, 3, 312-316.

199. Damrongkijkosol, C.; Kerdsuwan, S. Experiment Study on Influence of Compression Ratio onto Performance and Emission of Compressed Natural Gas Retrofit Engine. Master's Thesis, King Mongkut's Institute of Technology, Bangkok, Thailand, 2006.

200. Manivannan, A.; Chandrasekaran, S.; Ramprabhu, R. Lean Burn Natural Gas Spark Ignition Engine-An Overview; SAE Technical Paper 0148-7191; SAE International: Warrendale, PA, USA, 2003.

201. Abbasi Atibeh, P.; Brear, M.J.; Dennis, P.A.; Orbaiz, P.J.; Watson, H.C. Lean limit combustion analysis for a spark ignition natural gas internal combustion engine. Combust. Sci. Technol. 2013, 185, 1151-1168. [CrossRef]

202. Cartellieri, W.; Chmela, F.; Kapus, P.; Tatschl, R. Mechanisms leading to stable and efficient combustion in lean burn gas engines. In Proceedings of the International Symposium COMODIA, Yokohama, Japan, 11-14 July 1994.

203. Aziz, A.R.A.; Anbese, Y.T.; Hagos, F.Y.; Heikal, M.R. Characteristics of early flame development in a direct-injection spark-ignition CNG engine fitted with a variable swirl control valve. Energies 2017, 10, 964. [CrossRef]

204. Evans, R. Extending the lean limit of natural-gas engines. J. Eng. Gas Turbines Power 2009, 131, 032803. [CrossRef]

205. Chen, S.K.; Beck, N.J. Gas Engine Combustion Principles and Applications; SAE Technical Paper 0148-7191; SAE International: Warrendale, PA, USA, 2001.

206. Aljamali, S.; Abdullah, S.; Wan Mahmood, W.M.F.; Ali, Y. The effect of injection timings on performance and emissions of compressed natural-gas direct injection engine. J. Combust. 2016, 2016, 6501462. [CrossRef]

207. Wasiu, A.B.; Aziz, A.R.A.; Heikal, M.R. The effect of injection timing on the performance of natural gas with a high carbon dioxide $\left(\mathrm{CO}_{2}\right)$ content in a direct injection (di) gas engine. In MATEC Web of Conferences; EDP Sciences: Ulis, France, 2014; p. 02027. 
208. Zeng, K.; Huang, Z.; Liu, B.; Liu, L.; Jiang, D.; Ren, Y.; Wang, J. Combustion characteristics of a direct-injection natural gas engine under various fuel injection timings. Appl. Therm. Eng. 2006, 26, 806-813. [CrossRef]

209. Liu, L.-X.; Huang, Z.-H.; Jiang, D.-M.; Ren, Y.; Wang, J.-H.; Wang, Q. Combustion characteristics of a direct injection natural gas engine under various fuel injection timings. Trans. CSICE 2005, 5, 14.

210. Song, J.; Choi, M.; Kim, D.; Park, S. Combustion characteristics of methane direct injection engine under various injection timings and injection pressures. J. Eng. Gas Turbines Power 2017, 139, 082802. [CrossRef]

211. Hagos, F.Y.; Aziz, A.R.A.; Sulaiman, S.A. Methane enrichment of syngas $\left(\mathrm{H}_{2} / \mathrm{CO}\right)$ in a spark-ignition direct-injection engine: Combustion, performance and emissions comparison with syngas and compressed natural gas. Energy 2015, 90, 2006-2015. [CrossRef]

212. Hagos, F.Y.; Aziz, A.R.A.; Sulaiman, S.A. Syngas $\left(\mathrm{H}_{2} / \mathrm{CO}\right)$ in a spark-ignition direct-injection engine. Part 1: Combustion, performance and emissions comparison with CNG. Int. J. Hydrog. Energy 2014, 39, 17884-17895. [CrossRef]

213. Firmansyah. Optimization of Injection Parameters in Compressed Natural Gas Direct Injection (CNG-DI) Spark Ignition Engine; Universiti Teknologi Petronas: Tronoh, Malaysia, 2007.

214. Ehsan, M. Effect of spark advance on a gas run automotive spark ignition engine. J. Chem. Eng. 2010, 24, 42-49. [CrossRef]

215. Bell, S.R. Natural Gas as a Transportation Fuel; SAE Technical Paper 0148-7191; SAE International: Warrendale, PA, USA, 1993.

216. Dimopoulos, P.; Rechsteiner, C.; Soltic, P.; Laemmle, C.; Boulouchos, K. Increase of passenger car engine efficiency with low engine-out emissions using hydrogen-natural gas mixtures: A thermodynamic analysis. Int. J. Hydrog. Energy 2007, 32, 3073-3083. [CrossRef]

217. Khan, M.A.H.; Qidwai, M.O.; Chausalkar, A. Effect of variable ignition and injection timing on emission characteristics of SI engine using CNG and HCNG as fuel. Int. J. Adv. Mech. Eng. 2014, 4, 83-94.

218. Brower, M.; Petersen, E.L.; Metcalfe, W.; Curran, H.J.; Füri, M.; Bourque, G.; Aluri, N.; Güthe, F. Ignition delay time and laminar flame speed calculations for natural gas/hydrogen blends at elevated pressures. J. Eng. Gas Turbines Power 2013, 135, 021504. [CrossRef]

219. Kim, J.; Carley, D. Development of Direct Injection CNG Engine; Inha Technical College: Incheon, Korea, 2000.

220. Hagos, F.Y.; Aziz, A.R.A.; Sulaiman, S.A.; Mahgoub, B.K. Low and medium calorific value gasification gas combustion in IC engines. In Developments in Combustion Technology; InTech: London, UK, 2016.

221. Tilagone, R.; Venturi, S. Development of natural gas demonstrator based on an urban vehicle with a down-sized turbocharged engine. Oil Gas Sci. Technol. 2004, 59, 581-591. [CrossRef]

222. Hillstrom, D.R. Light Duty Natural Gas Engine Characterization; The Ohio State University: Ohio, CO, USA, 2014.

223. Ahmad, N.; Babu, M.G. Simulation and Experimental Studies on Combustion and Performance Characteristics for a Turbocharged and Naturally Aspirated Multi-Cylinder Compression Ignition Engine; SAE Technical Paper 0148-7191; SAE International: Warrendale, PA, USA, 2006.

224. Hupperich, P.; Dürnholz, M. Time-Controlled Pilot Injection for Stationary and Heavy-Duty Gas Engines; SAE Technical Paper 0148-7191; SAE International: Warrendale, PA, USA, 1997.

225. Ibrahim, A.; Bari, S.; Bruno, F. A Study on EGR Utilization in Natural Gas SI Engines Using a Two-Zone Combustion Model; SAE Technical Paper 0148-7191; SAE International: Warrendale, PA, USA, 2007.

226. Ibrahim, A.; Bari, S. An experimental investigation on the use of EGR in a supercharged natural gas SI engine. Fuel 2010, 89, 1721-1730. [CrossRef]

227. Sen, A.K.; Ash, S.K.; Huang, B.; Huang, Z. Effect of exhaust gas recirculation on the cycle-to-cycle variations in a natural gas spark ignition engine. Appl. Therm. Eng. 2011, 31, 2247-2253. [CrossRef]

228. Nitnaware, P.T.; Ganvir, V.M. Design development and analysis of exhaust gas recirculation system for $\mathrm{cng}$ fuelled si engine. IOSR J. Mech. Civ. Eng. 2015, 13, 27-35.

229. Ramasamy, D.; Zainal, Z.; Kadirgama, K.; Briggs, H.W.-G. Effect of dissimilar valve lift on a bi-fuel CNG engine operation. Energy 2016, 112, 509-519. [CrossRef]

230. Soid, S.; Amir, S.; Ismail, M.; Hamid, M.; Amzari, M.; Said, M. Simulation studies on the performance of small engine fuelled by methane and the effect of various valve timings. Indian J. Sci. Technol. 2015, 8. [CrossRef]

231. Bell, S.R.; Gupta, M. Extension of the lean operating limit for natural gas fueling of a spark ignited engine using hydrogen blending. Combust. Sci. Technol. 1997, 123, 23-48. [CrossRef] 
232. Suryawanshi, J.G.; Nitnaware, P.T. An Investigation on si Engine Using Hydrogen and CNG Blends; Department of Mechanical Engineering, Visvesvaraya National Institute of Technology, Nagpur \& DY Patil College of Engineering: Pune, India, 2011.

233. Mohammed, S.E.; Baharom, M.; Aziz, A.R.A. Analysis of engine characteristics and emissions fueled by in-situ mixing of small amount of hydrogen in CNG. Int. J. Hydrog. Energy 2011, 36, 4029-4037. [CrossRef]

234. Mohammed, S.E.; Baharom, M.; Aziz, A.R.A. The effects of fuel-injection timing at medium injection pressure on the engine characteristics and emissions of a CNG-DI engine fueled by a small amount of hydrogen in CNG. Int. J. Hydrog. Energy 2011, 36, 11997-12006. [CrossRef]

235. Tunestål, P.; Christensen, M.; Einewall, P.; Andersson, T.; Johansson, B.; Jönsson, O. Hydrogen Addition for Improved Lean Burn Capability of Slow and Fast Burning Natural Gas Combustion Chambers; SAE Technical Paper 0148-7191; SAE International: Warrendale, PA, USA, 2002.

236. Hagos, F.; Aziz, A.; Sulaiman, S. Investigation of deposit formation in direct-injection spark-ignition engine powered on syngas. Int. J. Automot. Technol. 2015, 16, 479-485. [CrossRef]

237. Kamel, M.M. Advanced Natural Gas Engine Advanced Natural Gas Engine Technology for Heavy Duty Vehicles; US Department of Energy: Washington, DC, USA, 2014.

238. LandiRenzo. Epa Approval of Dual Fuel CNG System for Detroit Diesel 12.71 s60 Engine; Landi Renzo USA: Torrance, CA, USA, 2013.

239. Wagemakers, A.M.L.M.; Leermakers, C.A.J. Review on the Effects of Dual-Fuel Operation, Using Diesel and Gaseous Fuels, on Emissions and Performance; SAE Paper 2012-01-0869; SAE International: Warrendale, PA, USA, 2012.

(c) 2018 by the authors. Licensee MDPI, Basel, Switzerland. This article is an open access article distributed under the terms and conditions of the Creative Commons Attribution (CC BY) license (http:/ / creativecommons.org/licenses/by/4.0/). 